\title{
تطوير بيئة تعلم تكيفية قائمة على انماط الدعم لتنمية مهارات التحدث باللغة الإنجليزية أنماطية
}

مخمد مخمود ابراهيم السيد

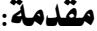

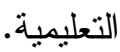

Herman Dwi Surjono, ويـرى

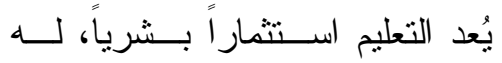

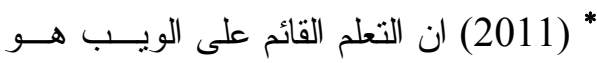

مدخلاته و عملياته ومخرجاته، نتيجة تدخل تطبيق يستتد إلى الوسائط المتعددة ويـستخدم التقنيات الحديثة في هذا الاستثمار ؛ لأنهــا تُشكل منهجاً منظماً للعملية التعليمية، ولذلك الخصائص و الموارد الموجودة لتوفير بيئـــة

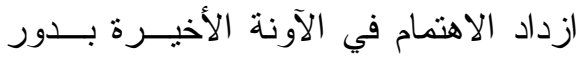

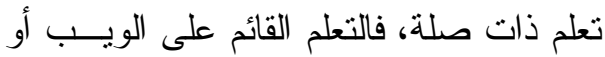
التكنولوجيا الحديثة، ومن ثم دار جدل كبير التعلم الألكترونى اصبح من مواضيع البحث

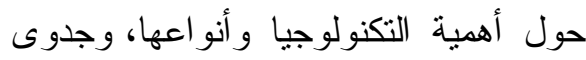
الأكثر شيو عا، و على الرغم من وجود الكثير الاستعانة بها، و أفضل الأساليب للاســتفادة

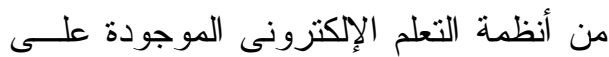

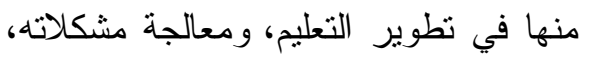

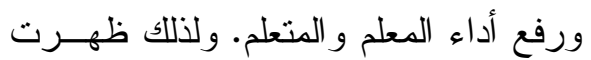

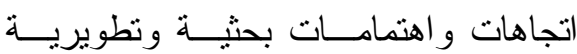
تشتهـف مجتمعات وبيئات التعلم التكيفيــة وظهرت ايضا بيئات التعلم التكيفية والتـى ولي ثبت فاعليتها في مهام التعليم. مناسبة فقط للطلاب المتجانسين ولمن لــديهخ لـوني استعداد ودافعية عالية فعندما يتم تتاول هـــه

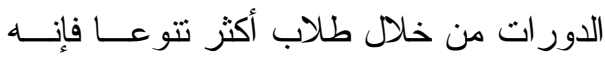
يمكن أن يكون هناك مشكلة. هؤلاء الطلاب

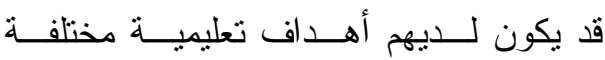
وخلفيات مختلفة ومستويات معرفية مختلفـــة و انماط تعلم مختلفة وكفاءات مختلفة. ولـــللك

ولقد اصبح الإنترنت وسيلة من اكثر

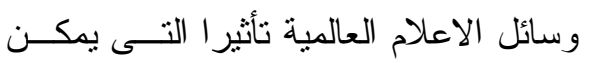
استخدامها لمشاركة وتبادل المعلومات وهذا

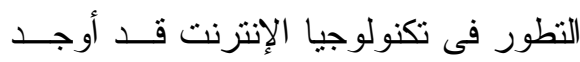
خبرات وتجارب للطلاب فى التعلم القـائم على الإنترنت و الذى يعــرف الأن بـــالتعلم

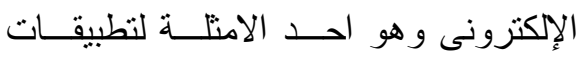

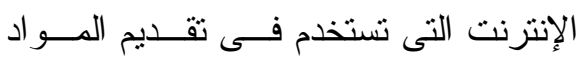




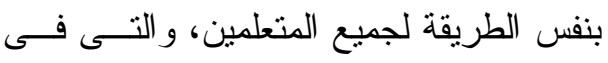

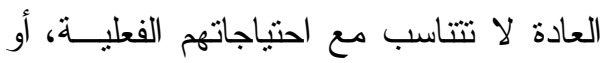

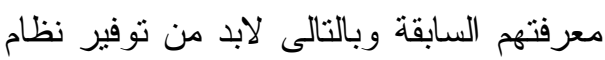

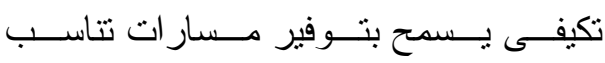

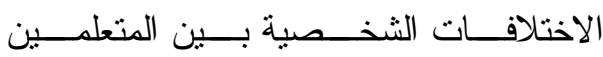
و احتياجاتهم.

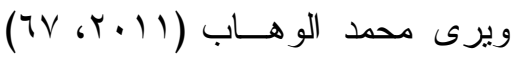

انه اصبح تكيف بيئة الـتـعلم مــن المحسـاور الأساسية التى لقيت اهتماما بالغا فى الاونـــة

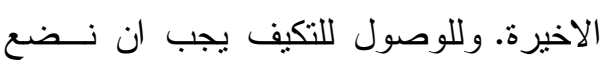

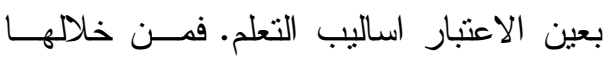

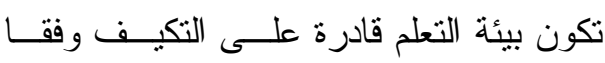

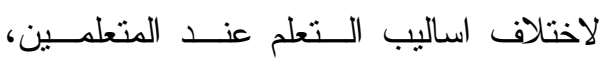
وبالتالى اصبح مهمة التطوير التى يقوم بهـــا المصممون من المهام الجوهرية التى نتنمل دئل على كثير من التحديات الكبيرة فى تــصميم بيئات التعلم الالكترونية.

كما ترجع فكرة أنماط الدعم إلى فكرة "فيجو تسكي Vygotsky "عن منطقة النمــو القـصوى The Zone Proximal Development فيه المتعلم أن يكون مستعداً لتعلم معلومة لا لا لان

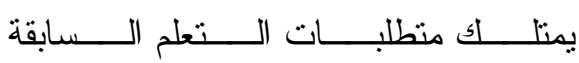
كالها، أو المعلومات الأخــرى التي تؤهله إلى اكتساب هذه المعلومة بــدون مساعدة، ويؤكد "فيجوتسكي" أن المتعلم يمكن لهن لهن أن يكتسب المعرفة إذا ما نم مساعدته علــى ولـى
فإن المحتوى التعليمى المعد لطلاب معينين قد لايكون مناسبا لطلاب اخرين. لذلك فإنه من الملح جدا تصميم محتوى مــرن قـائم

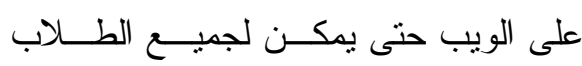

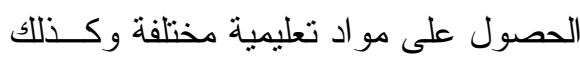
انماط عروض تقديمية مختلفة.

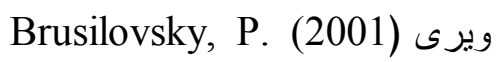
أنه من هذا المنطلق جاءت اساليب الــتعلم

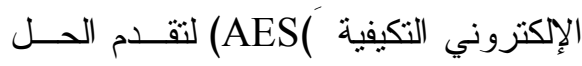
لهذه المشاكل وذلك بتعديل طريقــة تقــديم المحتوى حتى يتكيف مع كل طالب علـى لـى حدة. ولقد جاءت فكــرة أســاليب الــتعلم الإككترونى التكيفى من أنظمـــة الوسـائط الفائقة و انظمة الدروس الخصوصية الذكية

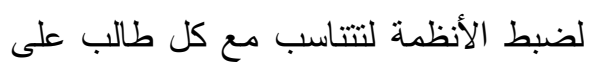

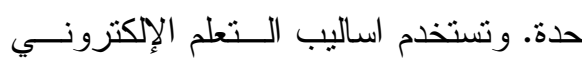
التكيفية نموذج المستخدم لجمع معلومسات

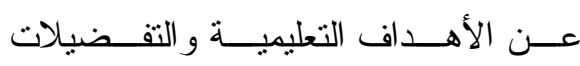

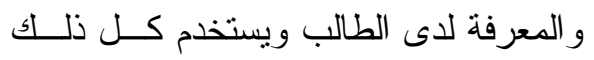
للتكيف وفقاً لاحتياجات الطالب.

و يوضح كلا من كلاسنجا و آخرون ولن

klasnja-Milicevic et , al, 2011, ) 212) انه بالرغم مما توفره بيئات الـتـعلم

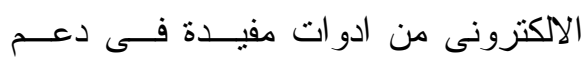

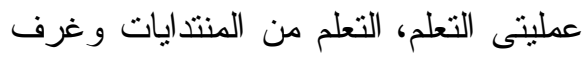

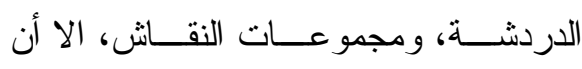
المحتوى و المصادر التعليمية يتم تقــديمهما 
الموجه الذي يصاحبه توجيه ومساعدة يحفــز المتعلم ويزيد من دافعيته وقابليته للتعلم.

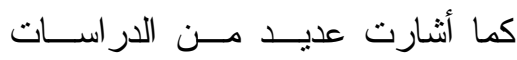

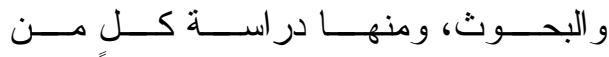
(Azevedo, ;(Hannafin et at, 2001): (إلى أن (Guzdial, 2004) ; et at, 2003) هناك أنو اعاً عدة من دعامات التعلم، ومنهــــا:

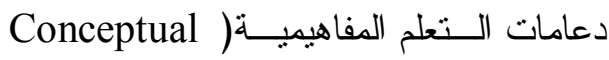
Scaffolding)، ودعامـــات الـــتعلم فـــوق

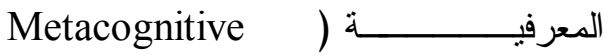

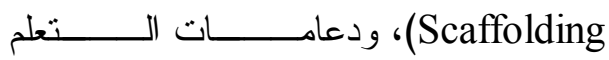
الاستر اتيجية (Strategic Scaffolding)

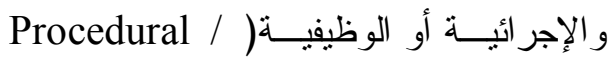
Functional Scaffolding ) و و الثخــصية أو الذاتية(Interpersonal Scaffolding)؛ ودعامات التو اصل، و النصائح، و المــساندة

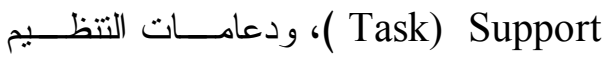
الخبير (Expert Regulation).

كما أن الموقــف التعليمــي وطبيعــة المهمة التعليمية هي التي تفرض علي المعلم أي دعامات التعلم أفضل و أكثر جدوى ونفعاً

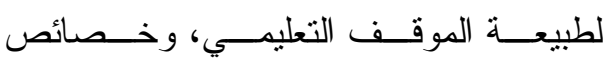

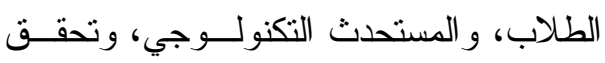
الهدف المطلوب وبكل يسر وسهولة، وهذا ما أوصت بــه در اســـة كـلـل مــن : Botnas, (Land, 2001 ،Liabry , 2001)
بناء النزركيب الذي يــضـع فيـــه المعلومـــة

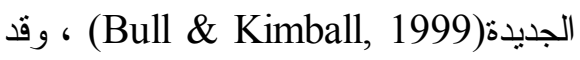
بتلقى المتعلم المساعدة من الزملاء - Peerstudent أو غير ذلك. وتتميز دعامات التعلم بعديـــــــن

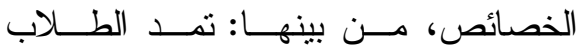
بالمساعدة، تعمل كأداة لتسهيل التعلم، توسع بلته وتتمي مهار ات الطلاب العقلية و العمليــة، تمكن الطلاب من إنجاز المهــام التــي لا لهارل

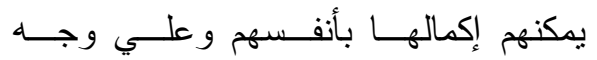
الخصوص المهــام التطويريـــة للمنتجــات الماتِ

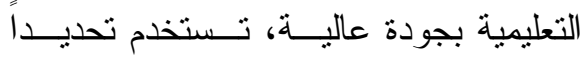
لمساعدة الطلاب عند حاجتهم لها وبـشكل مؤقت، حيث يجب أن يتم إز التها تـدريجياً

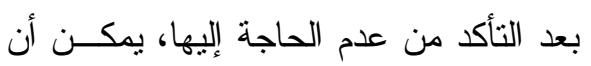

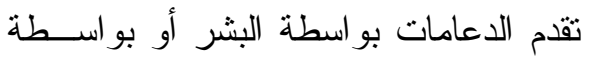
التكنولوجيا أو بدمج الاثثين معاً.

وتوكد البحوث و الدراسات التربوية،

منتل در اسة كـلـ مــن(Tergan, 1997) (Zhao, 1998) تعليمي مثر وفعال وأن هنالك حاجة ملحة

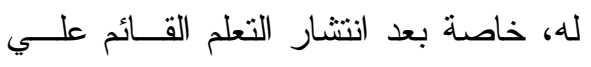
الحاسوب الذي يتسم بالمرونة و التفاعليــة،

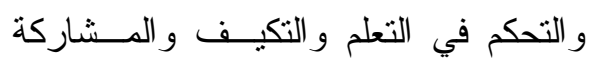
الإيجابية، و الاعتماد علي الــذات، فــالتعلم 
(Gery)

الدعم المتأصل فى النظام نفسه ـ فهو متكامل بشكل جيد لدرجة أنه يكون بالنسبة للعـاملين

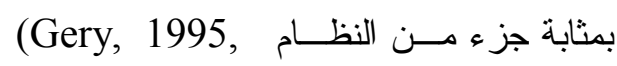

ثالثاً الدعم العرضي Extrinsic Support:

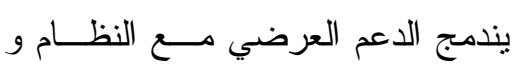
لكن ليس فــى مـسـاحة العمــل الابتــــئي لئي (Gery,1995,p.51)

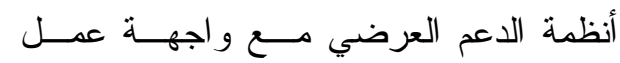

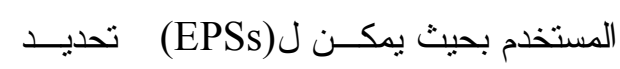
موقع المستخدم فى النظام أو حتــى المهمـــة

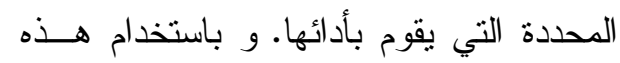

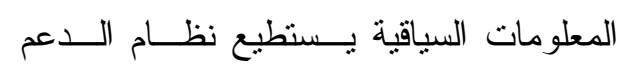

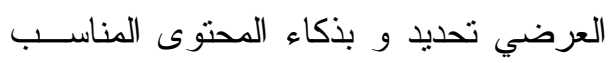

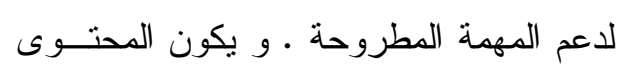

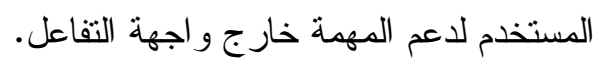
كما أن هنالك العديــــــــن الأدبيــات

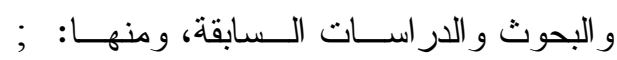
; Mcloughlin, 2000) Calais, 1985) (Randoll. Kalio, 2004 و الني تؤكد علي ضرورة أن يكون هناك تباين بـين تـصميم

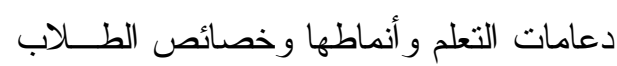

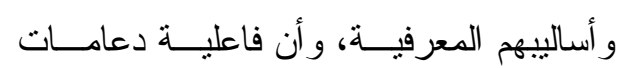

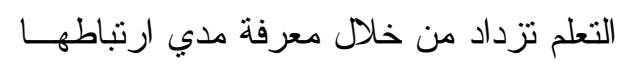
ببعض أساليب التعلم التي تتفاعل معها وتؤثر فيها.
أوصت بضرورة الاهتمام بتصميم دعامات التعلم، و التتويع في تقديم أنو اعها المختلفة.

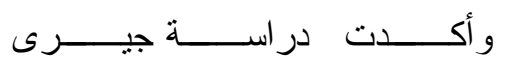
(Gery,1995) أساسية من الدعم الإككتروني(EPSs) و هم

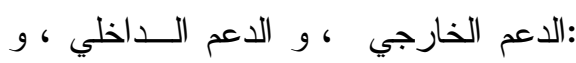

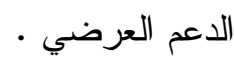

أولا أنظمة الــــعم الخـــارجي External :support

تقوم بتخزين المحتوى المستخدم فى دعم أداء المهام فى قاعدة بيانات خارجية .

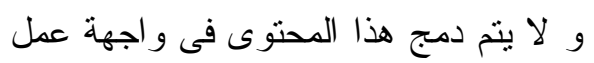

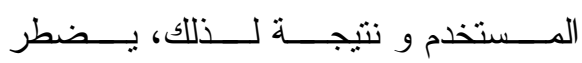
المستخدمون الى تحديـــــ المعلومـــات ذات

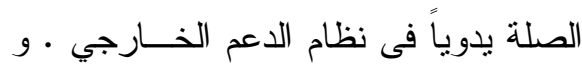
تتضمن نظم دعم الأداء الخارجي -الأكثـر

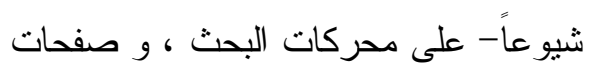

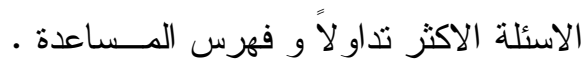

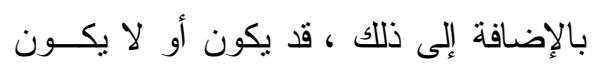

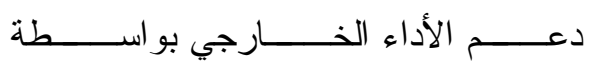

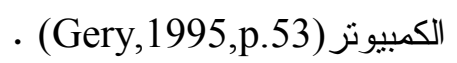
ثانياً الدعم الداخلي Intrinsic support: توفر هذه الانظمة للمستخدمين دعماً

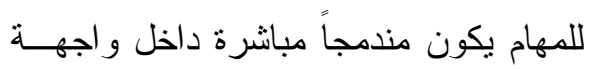

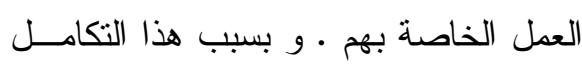

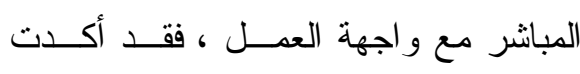


ونظر اً لما يتميز به عصرنا من ثورة

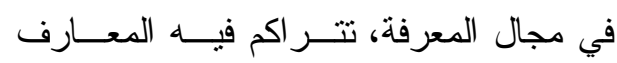

و المعلومات بشكل بتطلب سرعة ملاحقتهـــا،

فيجب علينا نحن المعلمين أن نعرف أهميــة

تدريب الطالب على المستحدثات التكنولوجية

الجديدة لتتمية المهار ات اللغوية لديه، ويــتخ

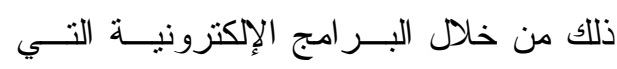

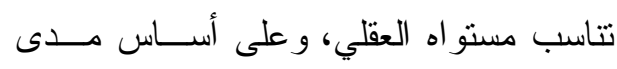

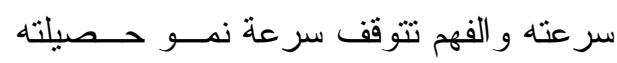

الثقافية على معرفة وفهم ما يجرى حوله من وند

أحداث، وبالتالي مدى قدرته على المـشاركة

في صنع الحياة في المجتمع الذى يعيش فيه.

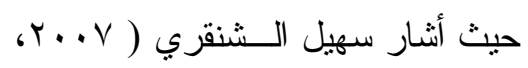

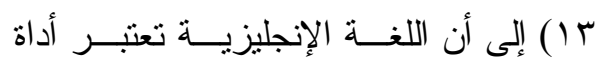

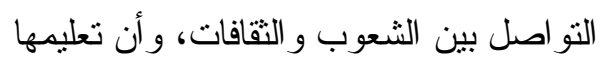

يساعدنا في الاستجابة لتحديات العالم و المعرفة

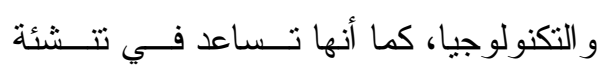
المو اطن الذي يدافع عن قيمه ودينه.

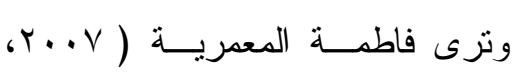

V P ا ( أن تعليم اللغة الإنجليزية من الركــائز

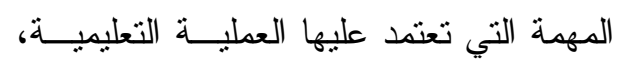

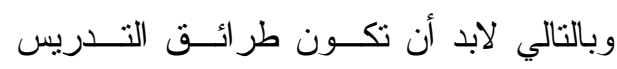

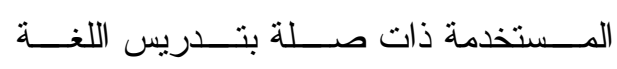
الإنجليزية بحيث تكون الأنشطة والتـدريبات بلته اللغوية هادفة.

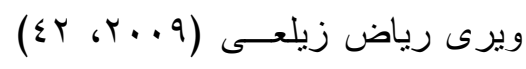

أنه لتعلم اللغات الأجنبية بصفة عامة و اللغـــة
وتؤكد البحوث و الدراســات مثــلـ

در اسة كل من (Tergan, 1997; Zhao, 1998; Land, 2000)

مدخل تعليمي مثنــر وفعــال، و أن هنــاك حاجة ملحة له، خاصة بعد انتـشار الــتعلم القائم على الكمبيوتز ، و الذي يتسم بالمرونة بله

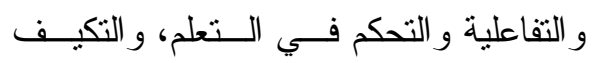

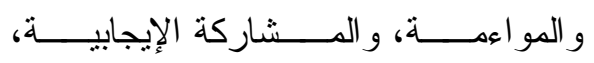

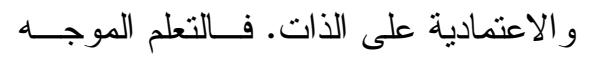
Guided Learning ومساعدة يحفز المتعلم، ويزيد من دافعيتــهـ وقابليته للتعلم، كما يثير لديه القدرة علــى ولى دئل

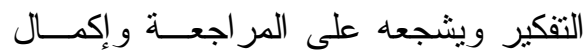

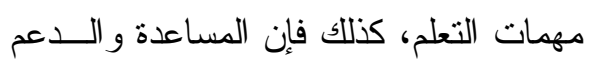
يقلل من العبء المعرفي الذي يقــع علــى عاتق المتعلم، حيث يتم إعداد الظروف التي لهي

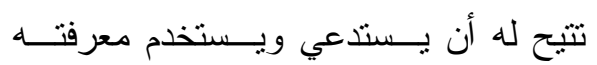

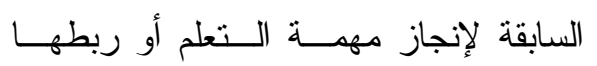

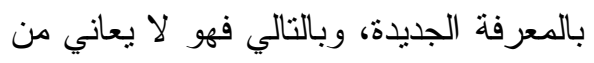
النتشت و الحيــرة أنتـــاء عمليـــة الــتعلم (McKenzie, 1999; McLoughlin \& Marshall, 2000) المتعلم احتمالات الفثل فــي أداء المهــــة المطلوبة، وتنساعده على إتمامهـــا معتمـــــاً على نفسه حتى يصل إلى مستوى الكفــاءة المطلوب Winnips \& McLoughlin, 2000). 
التكيفية لتتمية التحدث باللغة الإنجليزية، عن طريق تصميم و إعداد بيئة تكيفية تتعلق بتتمية

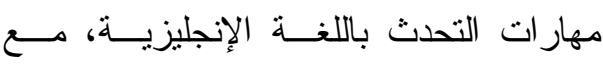
توصيفها توصيفاً دقيقاً باستخدام معايير البيئة

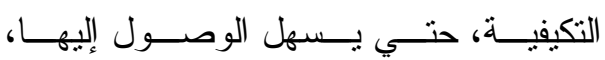
و استرجاعها في أي وقت باستخدام محركات البحث المختلفة المتو افرة بالبيئة. الإحساس بالشكلة: - المان

لاحظ الباحث من خلال عملــهـ فـي

الميدان التعليمي بعض المشكلات التي نواجه الطلاب فى العمليه التعليمية ومنها مهــار ات لتهية

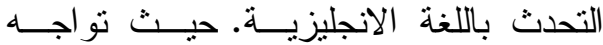

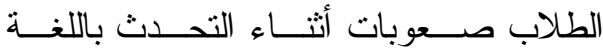
الانجليزية مما يؤثر على تعبير هم عن الذات،

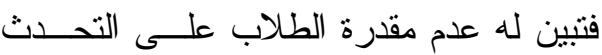

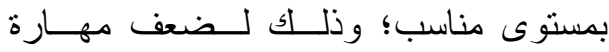

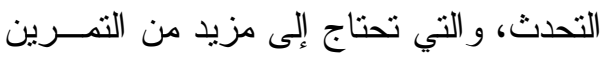

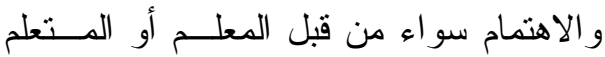
داخل الفصل الدراسي، وأن هناك قصور في البر امج التدريبية المقدمة لهم. وقد أكدت الار اســات أهميـــة البيئـــة التكيفية ودور ها الكبير في العملية التعليمية، ولكن الباحث لاحظ أن بعض الدراسات تؤكد

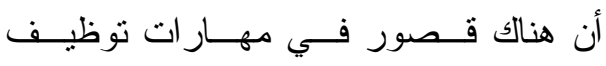

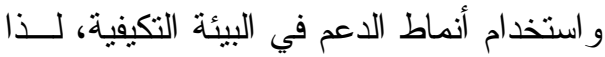
كان هناك ضرورة لعمل بيئة تكيفيــة قائمـــة

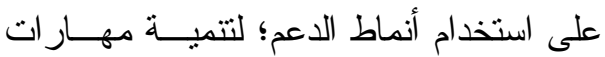
التحدث باللغة الإنجليزية.

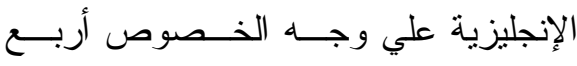

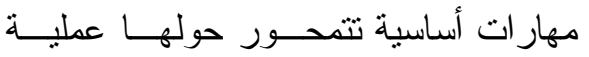
اكتساب اللغة و هذه المهار ات هي (مهــارة

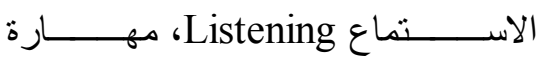

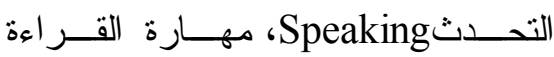

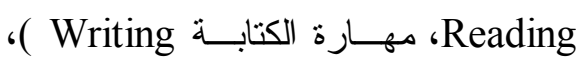

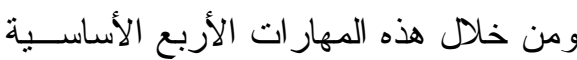

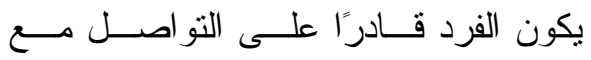
الآخرين قر اعةً وكتابةً و استماعاً وتحدثاً.

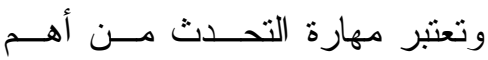
المهار ات الأربع التى يعتمد عليها المــتعلم

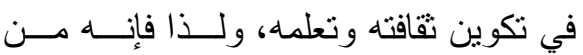
الضروري التركيز على هذه المهارة بشكل لئل

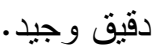

Mary اتفــق كـل مــن )

Melanie , Alan Pulverness, Spratt على أهميــة مهــارة Williams, 2014) المحادثة ، حيث هدفت الدر اسة إلى تحسين

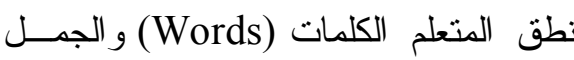
(Structure) و التزر اكيــــب (Sentences) وجميـع الحـروف الــصوتية الــساكنة

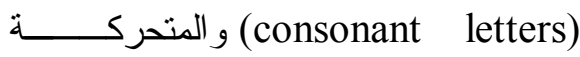
بطريقــة سـليمة مـــع (vowel letters) مر اعاة النغــــة (Intonation) و النبــر ) stress ) ولذا فقد استهدف الباحث من خــله هذه الدراسة توظيف نقتيات بيئــة الـتـعلم 
وأسفرت نتائج الاراسة الاستكثافية علـم الاتي:

1 - أن 10 \% من أفــر اد العينـــة لــديهم

صعوبات في مهار ات التحدث باللغـــة

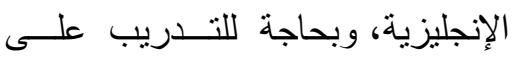

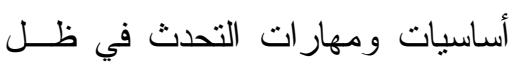

أنماط الدعم فى البيئة التكيفية، حيــــ

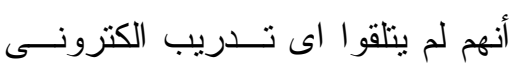

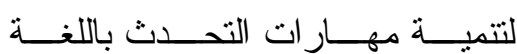

$$
\text { الإنجليزية. }
$$

r-اطلاع الباحث على الدراســات والأدبيــات

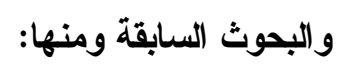

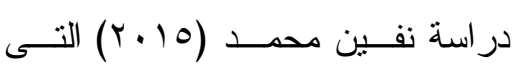

هدفت إلى بيان أثز تصميم بيئــة افتز اضـــية

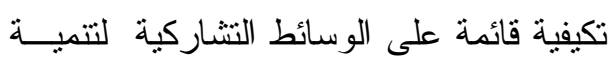

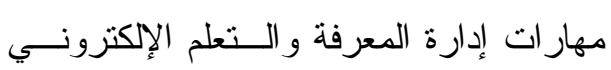

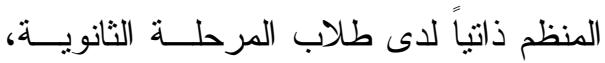
وتوصلت الدراسة إلى فاعلية البيئة التكيفيــة

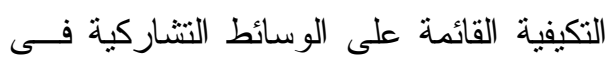

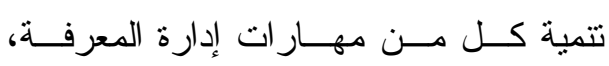
ومهار ات التعلم الإلكتروني المــنظم ذاتيــاً، وأوصت بنشر الثقافة الإلكترونية من خـــلال

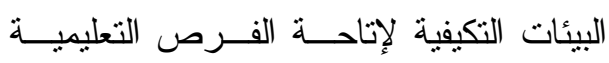

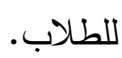

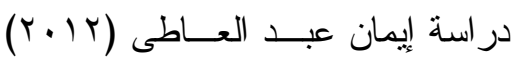
التي هدفت إلى تحديد أثز اخـتـلاف أنـــاط

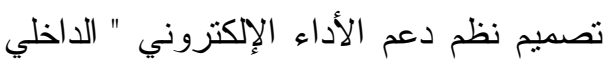

وقد شعر الباحث بوجــود مـشكلة البحــث الحالي من خلا الآتي:

ا- خبرة الباحث كمـــرس لغـــة اتجليزيـــة بالمرحلة الثانوية:

حيث لاحظ الباحث من خلال عملــه

ضعف مهار ات التحدث بالمرحلة الثانويـــة بصورة متفاوتة بين الطلاب، وندرة فرص بله

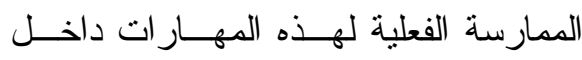
الفصل الدر اسي. ب-الار اسة الاستكثافية: - بل

حيث قام الباحث بــإجر اء در اســة

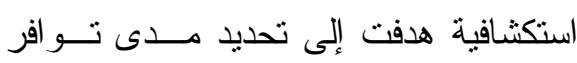

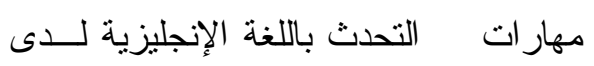
طلاب المرحلة الثانويــة (الــصف الثـاني الثانوي)، ومدى الحاجة لاستخدام وتوظيف

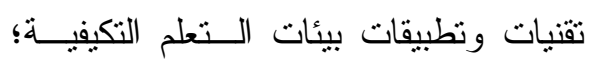
لتتمية تلك المهار ات كاتجاه حديث للتعلــيم

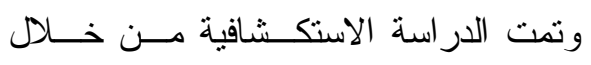

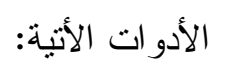

تطبيق استبيان على عينة من طلاب المرحلة الثانوية (الصف الثـاني الثـانوي) بمدرسة تمي الامديد الثانوية بإدر اة تمــي

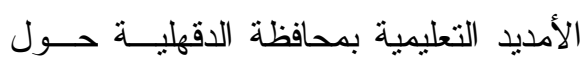

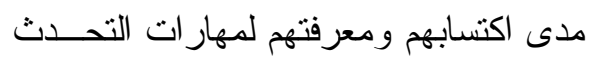
باللغة الإنجليزية، وهل تلقو ا بر امج تدرييية

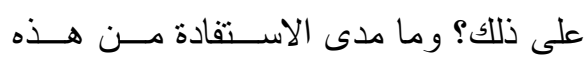

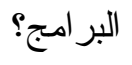


وتوصي بأنه يجب على المؤسسات التعليمية

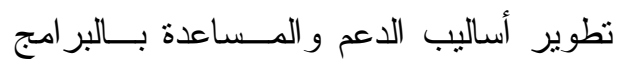
التعليمية الخاصة بها.

وتوصلت دراسة" هنريش، و وميلنى،

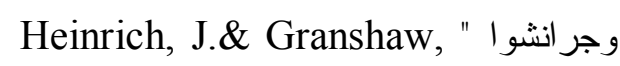
(2012) أن القائمين على تصميم البرمجيات

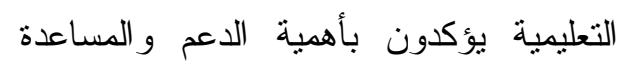
داخل البرامج التعليمية مع مر اعاة اختبار أنماط الدعم المناسبة وفق ظروف المحتوى

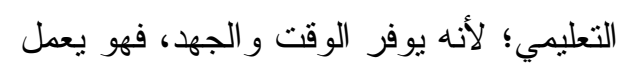

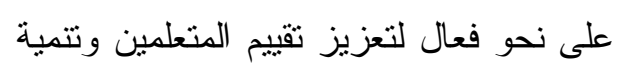

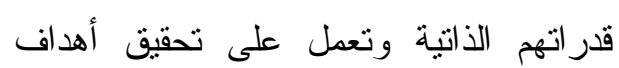
التعلم.

وتؤكد دراسة "كوميرس وآخرون"

Kommers, et al (2008)

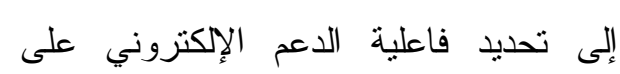

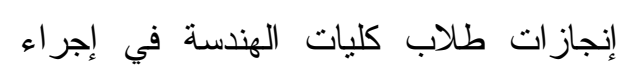

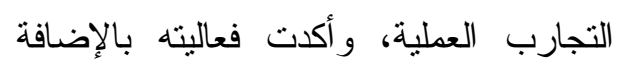
إلى أن الدعم المقدم ساعد الطلاب في التحكم

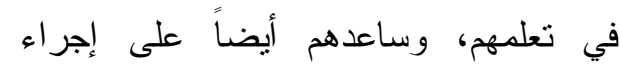
التجارب بتمكن وكفاءة عالية، و أكدت نتائجها على ضرورة تفعيل أنظمة الدعم الإكترونية في المشاكل غير المنتظمة والتي تتطلب تحليلاً وتأليفاً بين العناصر المختلفة؛ فهي تساعد المتعلم على أن يبحث عن المعلومة

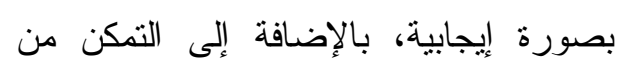
تطبيقها بطريقة سهلة ومبسطة.
- العرضي - الخارجي" القائمة على الويب على التحصيل المعرفي والأداء المهــاري المرتبط بمهار ات استخدام السبورة الذكية،

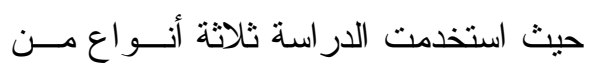
أنماط الدعم الإلكتروني وهى: نمط الــدعم

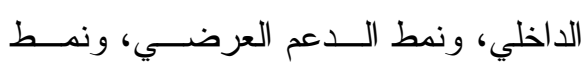
الدعم الخارجي، و أكدت نتائجها على زيادة

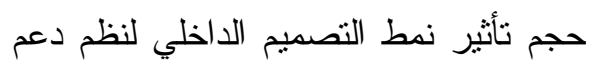
الأداء الإككتروني بالمقارنة بنمطي التصميم (العرضي - الخارجي) علــى التحــــيل المعرفي و الأداء المهاري لدى مـستخدمي تللك النظم، وقد أوصت الباحثة بــضرورة

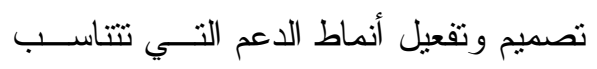

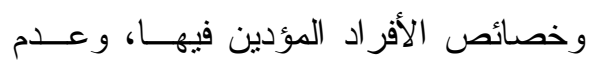
تركهم للأساليب العشو ائية في دعــم الأداء

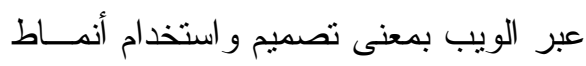

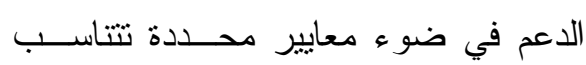
وخصائص الأفر اد المؤدين.

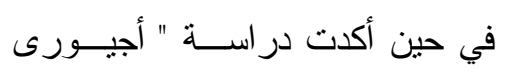
وكومــــادا " Aguirre \& Quemada

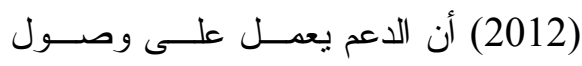

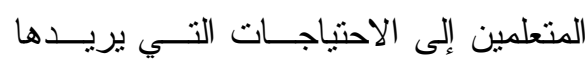
بسهولة ويسر، حيث يوفر الدعم و المساعدة

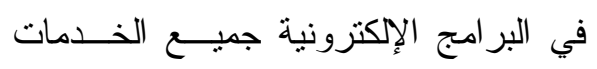
و المصادر التي تساعده في تحقيق الأهداف

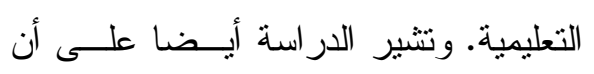

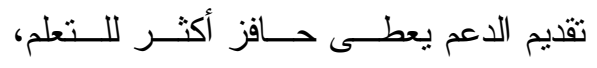


بعد التأكد من عدم الحاجة إليهـــا، يمكـنـ أن

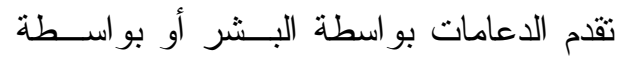
التكنولوجيا أو بدمج الاثثين معاً.

وتوكد البحوث و الدراسات التربويــة، منل در اسة ( (Zhao, 1998) أن دعامــات

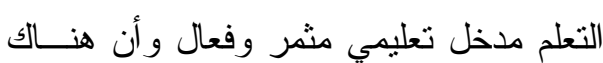

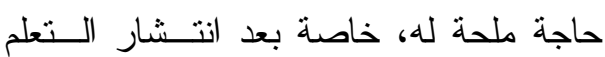
القائم علي الحاسوب الذي يتــسم بالمرونـــة

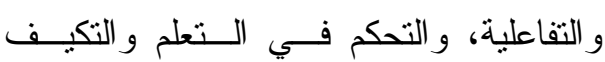

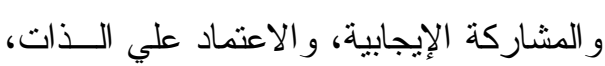

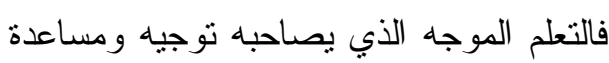
يحفز المتعلم ويزيد مــن دافعيتــهـ وقابليتــهـ للتعلم.

لذا يسعى البحث الحالي لدراسة أثــر

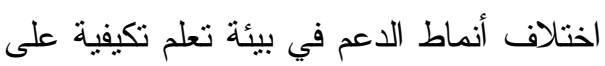

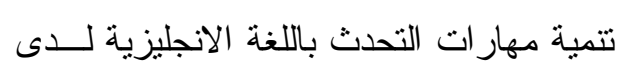
طلاب المرحلة الثانوية

\section{تحديد مشكلة البحث:}

مما سبق يمكن تحديد مشكلة البحـــث

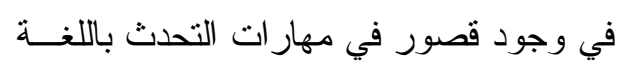

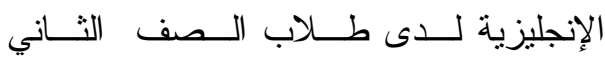
الثانوي، ويمكن تحديد مشكلة البحــث فـي لئي السؤ ال الرئيسي الأتي:

ما أثز اختلاف أنماط الدعم في بيئـــة تعلم تكيفية على تتمية مهار ات التحدث باللغة

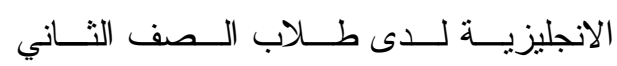

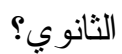

و وأوضح "بــاركير ا وفانـشيوك و

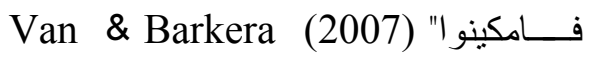
Famakinwa \& Schaik استهدفت استخدام الدعم الاككتروني القـائم على السقالات التعليمية على أداء الطــلاب

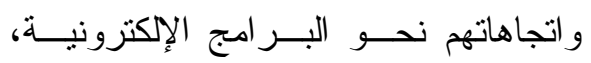

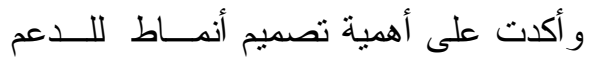

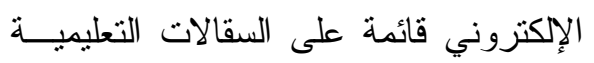
لاستخدامها في تحسين أداء الطلاب للمهام، وأكدت نتائجها على فاعلية استخدام الــدعم الالكتروني القائم على السقالات التعليميـــة فى البرامج الإككترونية؛ حيث أنها تجعــل

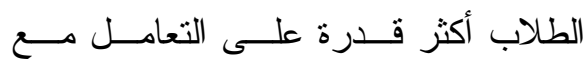
المتطلبات المطروحة عليهم، ويساعد فـي تغيير الاتجاهات بصورة إيجابية، ويعدـلــل على تحفيز وتعزيز قدر اتهم علــى الـتـعلم

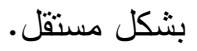
وتتميز دعامات التعلم بعديـــــــن

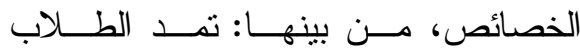
بالمساعدة، تعمل كأداة لتسهيل التعلم، توسع بلته وتتمي مهار ات الطلاب العقلية و العمليــة، تمكن الطلاب من إنجاز المهــام التــي لا ولهابل

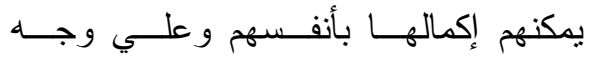

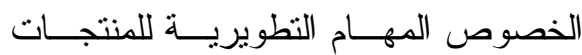
التعليمية بجودة عاليــة، تــستخدم تحديــــاً

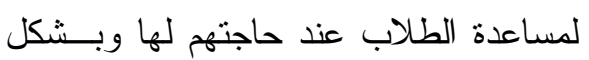
مؤقت، حيث يجب أن يتم إز التها تــدريجياً 


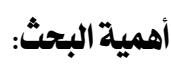 \\ قد يسهم البحث الحالي في:}

أولاً: بالنسبة لطلاب المرحلة الثانوية:

1- مساعدة المتعلمين على تتمية مهار ات

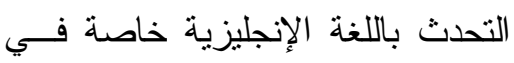

ضوء اختلاف أنماط الدعم فـــي بيئــة

التعلم التكيفية.

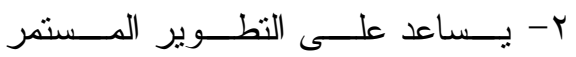

للمتعلمين، وحثنه على متابعة الجديـــ

في التخصص.

ثانياً: بالنسبة للمؤسسات التعليمية:

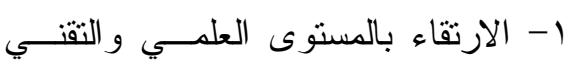

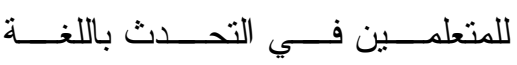

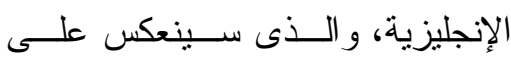

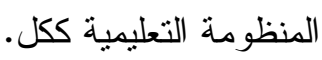

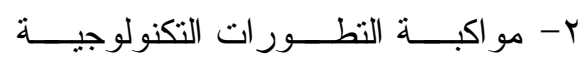

و الاتجاهات الحديثة في التعليم.

ثالثاً: بالنسبة للبحث العلمي:

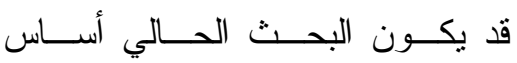

للار اسات و أبحاث منطورة جديــدة لأنمـاط لبـاط

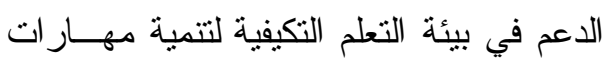

التحدث باللغة الإنجليزية.

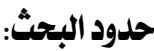

1- سوف يقتصر البحث على عينة مــن

طلاب الصف الثاني الثانوي بمدرســة

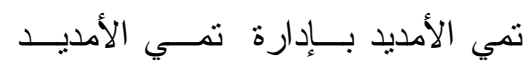

التعليمية- محافظة الدقهلية.
ويتفــرع عـن هــذا التــساؤل الأســـئة

الأتية:

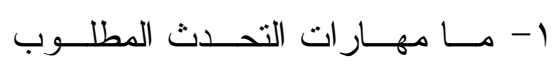

تتميتها لدى طلاب الــصف الثـاني

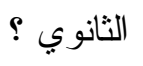

r- ما المعايير التربوية و الفنية لتصميم

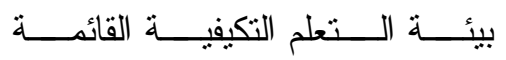

على اختلاف أنماط الـــــم للتميـــة

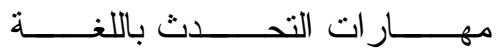

الإنجليزية؟

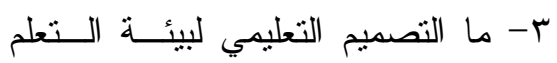

التكيفية القائمة على اختلاف أنمـاط لئهي

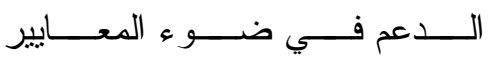

و الاحتياجات لتتمية مهار ات التحدث

باللغة الإنجليزية؟

ع- ما أثز اختلاف أنماط الدعم (داخلي- بالهي

خارجي - عرضي) في بيئة الـتـعلم

التكيفية على تتمية مهار ات التحدث

باللغة الإنجليزية؟

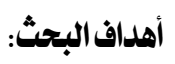

يهذف البحث الحالي إلى قياس أثــر

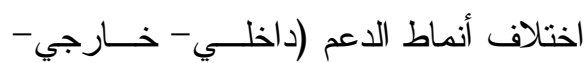

عرضي) في بيئة التعلم التكيفية في تتميــة

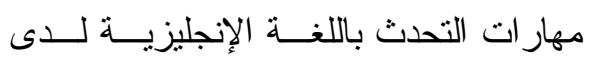
طلاب الصف الثاني الثانوي. 


$$
\begin{aligned}
& \text { ب- اربع وحسـدات مــن مقـرر اللغـــة أدوات البحث : }
\end{aligned}
$$

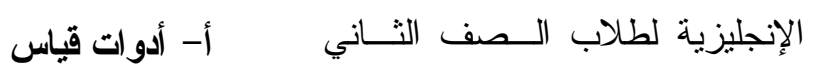

1- اختبــار التحــدث باللغـــة الانجليزيـــة

.Speaking Test

r- مقياس تحليل مهار ات التحــدث باللغـــة

الانجليزية Speaking Rubrics.

$$
\begin{aligned}
& \text { ب- أدوات جمع المعلومات } \\
& \text { 1- قائمة مهار ات } \\
& \text { ץ- قائمة معايير } \\
& \text { ب- قائمة أهداف } \\
& \text { ج- أدوات المعالجة: }
\end{aligned}
$$

1- البيئة التكيفية بأنماط الدعم (داخلــي-

$$
\begin{aligned}
& \text { خارجي- عرضي). } \\
& \text { Y- قائمة معايير } \\
& \text { r- قائمة أهداف } \\
& \text { متغيرات البحث: }
\end{aligned}
$$

اشتنمل البحث الحالي على المتغيــر ات

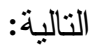

المتغيــرات المـسـتقلة: Independent

Variables

أنماط الــدعم (داخلــي- خـــارجي-

عرضي) في بيئة التعلم التكيفية.

المتغير التابع: Dependent Variables

- مهار ات التحدث باللغة الاتجليزية.

$$
\text { التصميم التجريبي للبحث: }
$$

اتبع الباحث التصميم شبه التجرييـي لبيائي
Unit 1, Unit 2 , (الثانوي وهيريه

.(Unit 3 , Unit 4

$$
\text { r- أنماط الدعم: }
$$

تتاول البحث ثلاث انماط من الــدعم

الاول (داخلي ) و الثاني (خارجي) الثالـــث

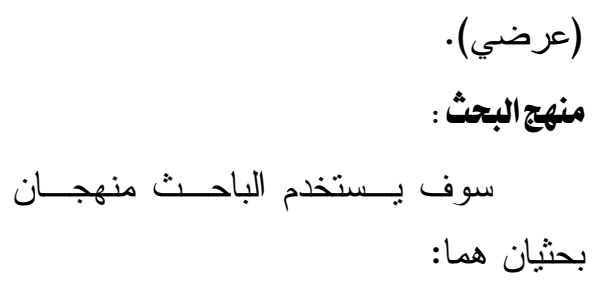

$$
\text { المنهج الوصفي التحليلي: }
$$

سوف يستخدم في وصف وتحليـلـل

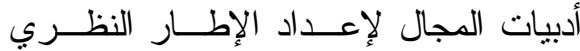

و البحوث و الدراسات السابقة ذات الــصلة

بالموضوع الخاص بمشكلة البحث. وتحديد

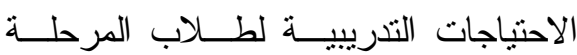

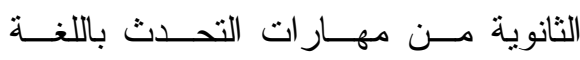

الانجليزية.

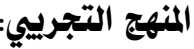

سوف يستخدم للتحقق مــن صــحة

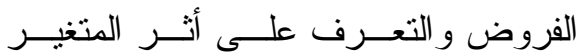

المستقل (اختلاف أنماط الــــعم فــي بيئــة

التعلم التكيفية) على المتغير التابع (مهار ات

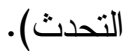




\begin{tabular}{|c|c|c|c|}
\hline تقويم بعدي & معالجة تجريبية & تقويم قبلي & \\
\hline $\mathbf{O 2}$ & $\mathrm{X} 1$ & 01 & مجموعة الدعم الداخلي \\
\hline $\mathbf{O 2}$ & $\mathrm{X} 2$ & 01 & مجموعة الدعم الخارجي \\
\hline $\mathrm{O} 2$ & $\mathbf{X 3}$ & 01 & مجموعة الاعم العرضي \\
\hline
\end{tabular}

طلاب المجموعة التجريبيـــة الثانيـــة

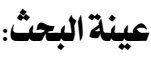
قبلياً وبعدياً في اختبار التحدث لصالح تكونت عينة البحث من ( •9) طالبــاً التطبيق البعدي.

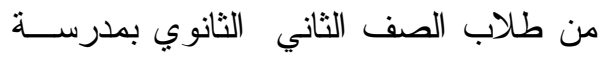
r- يوجد فرق دال إحصائياً عند مستوى دلالة (0., •) بين متوسطي درجات تمي الأمديد بإدارة تمي الأمديد التعليميــة-

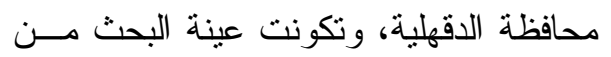

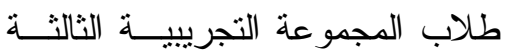
قبلياً وبعدياً في اختبار التحدث لصالح ثلاث مجموعات تجريبية قوام كل مجموعة

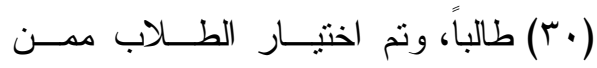

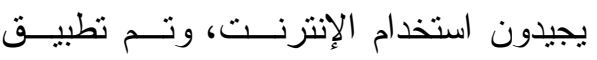
ع- لا يوجد فــرق دال إحــصائياً عنــــ

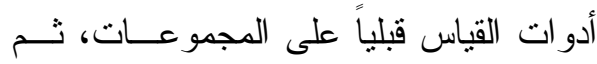

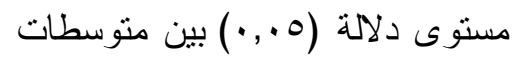
درجات طلاب المجموعات التجرييية الثلاث في النطبيق البعدي لاختبـــار التحدث باللغة الانجليزية.

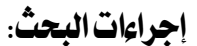

للإجابة عن تساؤلات البحث والتحقى من صحة فروضه اتبع الباحث الخطوات التالية:

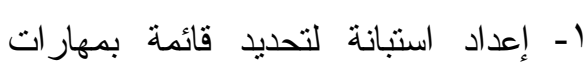
التحدث باللغة الإنجليزية لدى طلاب

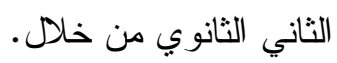

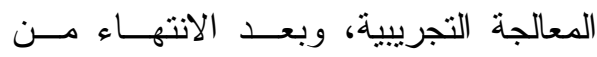
التجربة، يتم تطبيق أدوات القياس بعدياً.

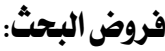
سعي البحث الحالي من التحقق من صحة

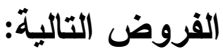
1- يوجد فرق دال إحصائياً عند مستوى دلالة (0., •) بين متوسطي درجات

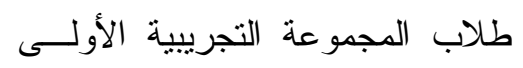
قبلياً وبعدياً في اختبار التحدث لصالح التطبيق البعدي. - الاطلاع علي الدراسات و الأدبيات

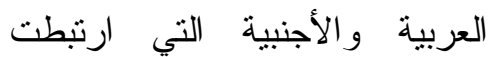
r- يوجد فرق دال إحصائياً عند مستوى دلالة (0., ) بين منوسطي درجات 
0- تصميم بيئة تكيفية قائمة على اخـتلاف

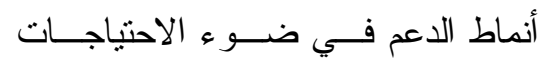

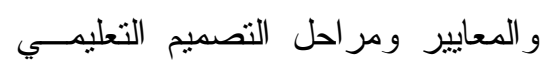

التالية:

- مرحلة الدر اسة و التحليل

- مرحلة التصميم

- مرحلة الإنتاج

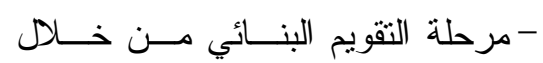

التحكم و الدر اسة الاستطلاعية.

ج- بناء أدو ات الدر اسة وتتمنل في الآتي:

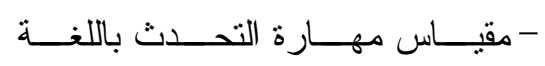

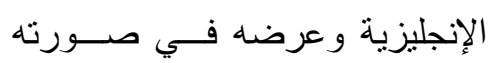

الأولية على مجمو عة من المحكمـين

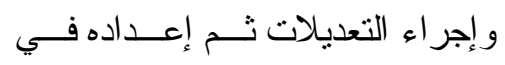

صورته النهائية.

V- اختيار طــلاب العينــة الاســنطلاعية،

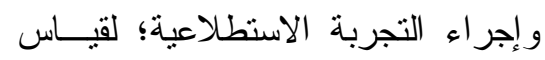

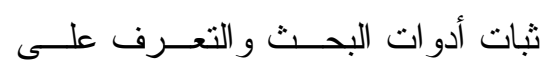

المشكلات التي سنواجه الباحث أثتــاء

التطبيق كذلك الزمن اللازم للمعالجة.

ᄉ- اختيار عينة الدراسة، وتقسيمها علـى

المجموعات التجريبية الثلاث عشوائياً،

المجموعة الأولى سوف تستخدم بيئـة

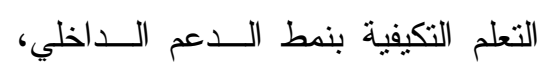

المجموعة الثانية سوف تــستخدم بيئـة

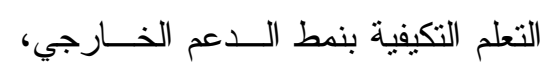

بموضوع البحث وبناء أدو اته.

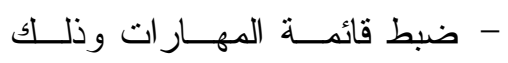

بعرضها علـي مجموعــة مــن

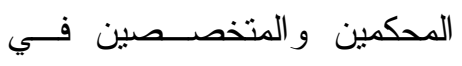

مجال تكنولوجيا التعليم، و التصميم

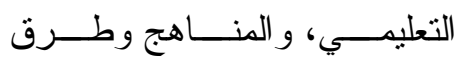

التدريس، ثم تعديل القائمة وفقــاً

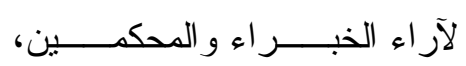

و التوصل للقائمة النهائية لمهار وات

التحدث.

r- اثتقاق قائمة بالمعايير التصميمية لبيئة

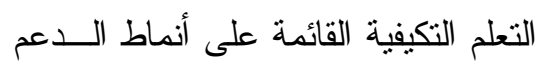

لدى طلاب المرحلة الثانوية ثم عرضها لنياطئ

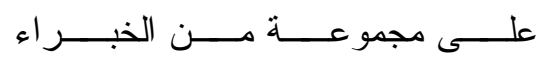

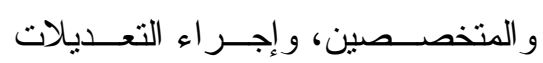

المطلوبة ومن ثم اعداد قائمة المعسايير ولئاء

التصميمية النهائية.

r- تحديد قائمة بالأهداف التعليمية المــر اد

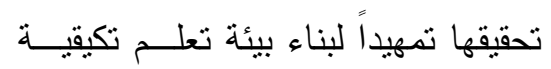

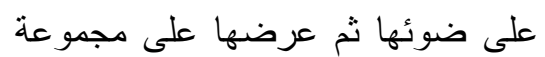

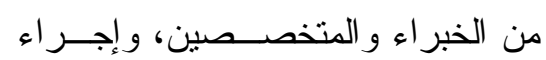

$$
\text { التعديلات المطلوبة. }
$$

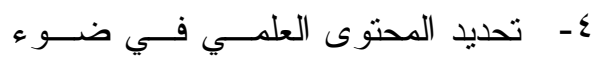

الأهداف ثم عرضه على مجمو عة مـن

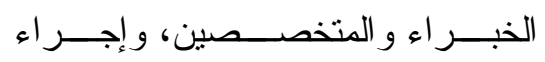

$$
\text { التعديلات المطلوبة. }
$$


تعليمي داخلي وخارجي وعرضي لطــلاب

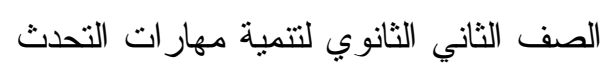

باللغة الاتجليزية.

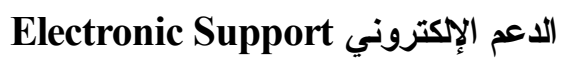

يعرفه الباحث إجر ائياً بأنه نظام يقدم

مساعدة إلكترونياً وفقا لأنماط الدعم (داخلي

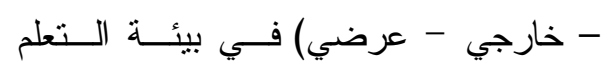

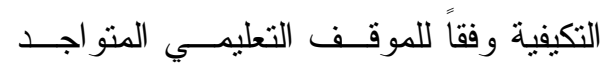

بحيث يقلل من تشنتيت طلاب الصف الثاني

الثانوي ويوجهه نحو ما يريدون بأقل جهد

$$
\text { وفى أسرع وقت. }
$$

Speaking Skill مهارة التحلث وفرع

يعرف الباحث مهارة التحدث إجرائياً

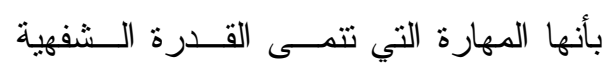

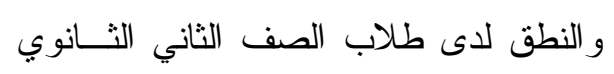

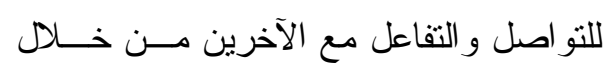

بيئة التعلم التكيفية.

الإطار النظري للبحث:

يهدف الباحث مــن إعــداد الإطــار

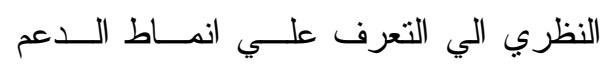

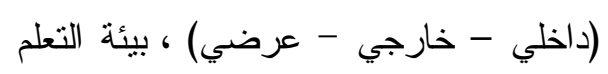

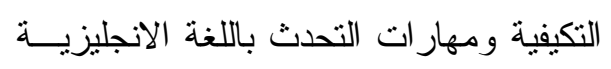

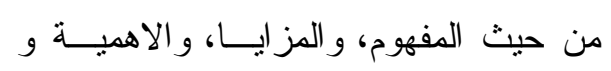

$$
\text { الخصائص. من هن }
$$

Adaptive : أولا : بيئات التعلم التكيفية

\section{Learning Environment}

"في ظل النز ايد الـــريع للتطــــور ات
المجمو عة الثالثة سوف تـستخدم بيئــة التعلم التكيفية بنمط الدعم العرضي . 9- تدريب الطلاب على كيفية استخدام بيئة

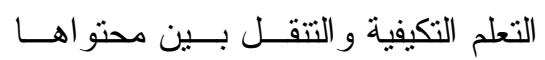

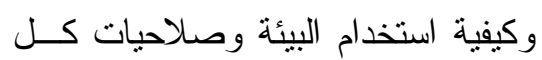
فرد على النظام.

• ا-إجر اء التجربة الأساسية للبحث ذلك كما يلى

- تطبيق أدوات البحث قبلياً على عينــة

$$
\text { البحث (مقياس مهار ات التحدث). }
$$

- المعالجة التجريبية للمحتوى التعليمي

$$
\text { من خلال النظام للطلاب المختارين. }
$$

- تطبيق أدوات البحث بعدياً على عينة

$$
\text { البحث (جميع الادوات). }
$$

1 ا ـمعالجة البيانات المستقاه من التطبيقــين

القبلي و البعدي بــالطرق الإحــصائية

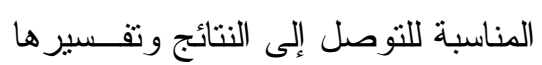

في ضو ء الإطار النظري ونتائج البحوث المرتبطة وفروض الدر اسة.

rا -تقديم التوصيات و المقترحات فى ضوء ما أسفرت عنه نتائج البحث.

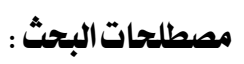

Adaptive البيأـــــــــة التكيفي

\section{Environment}

يمكن تعريف بيئة التعلم الإلكترونيــة

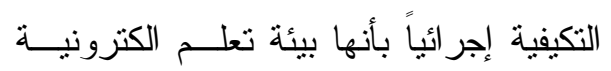
مرنة تر اعى خصائص المتعلمين ونوفر دعم 
ولكي يستطيع النظام أداء منل هــذه

المهام (أي أن يكون النظام تكيفيًا)، فإنه يُينى يُّي

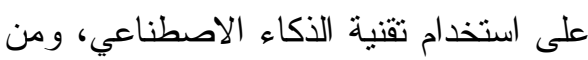
هنا ظهر ما يعرف بــنظم الــتعلم التكيفيــــة

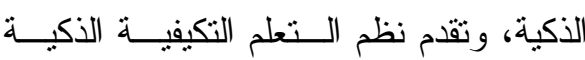
المقرر أو المحتــوى التعليمــي المناســبـ للحاجات التعليمية المختلفة للمتعلمين، فـي لـي ضوء المعارف والخبر ات السابقة للمتعلمين، و على أسـاس المداخل و النظريات التعليميــة،

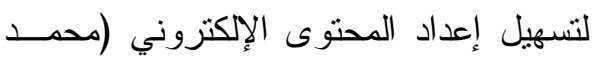
خميس، 10 • بأ، . ب (1).

\section{ا - بيئات التعلم التكيفيــة $\quad$ Adaptive} Learning Environment

(Wauters, يرى وترز ودامسـيت

Desmet and Van den Noortgate (2010, أن التعلم التقليدي يتمحــور حــول

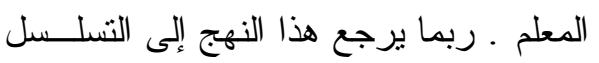
الهرمي الاجتماعي الذي يفرض على التعلم

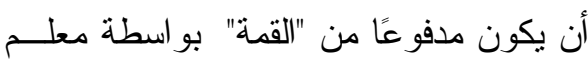

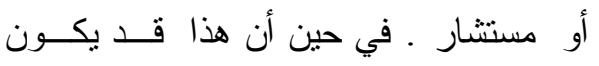

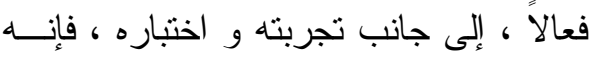

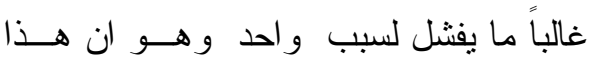
النوع من التعلم مبنى على الافتر اض القائل

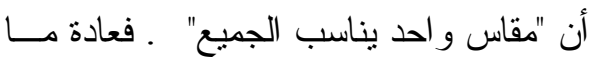
تتبع النماذج المتمحورة حول المعلم فلـــفة "خذها أو انركها" ، حيث غالبًا مـــا تُعتبـــر

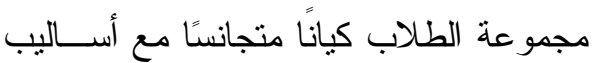

التكنولوجية أصبح التعلم مدى الحياة مطلبـاً وضرورة. وقد أناح التعلم الإكترونى فرصاً

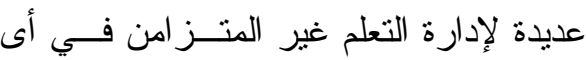

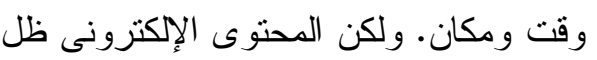

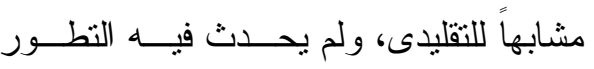

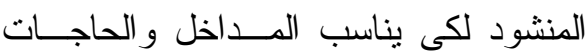
الثخصية للمتعلمين. وتهدف نظـــم الـتـعلم

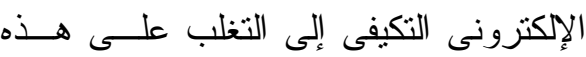
المشكلة. وخلال الأربع عشرة سنة الماضية المئية أصبح إنشاء المحتوى الإكترونــى للــتـلم التكيفى، وتوصيله، جز عاً مهماً في تــصميم الإكترني Vassileva, ) نظم ومنصات التعلم المتقدمة جهاء

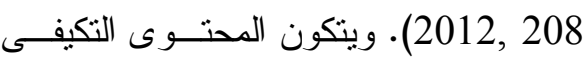

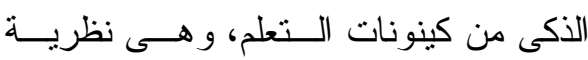

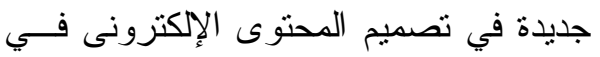

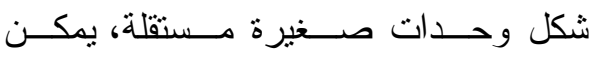
استخدامها بشكل منفصل أو بالاندماج مــع وهي

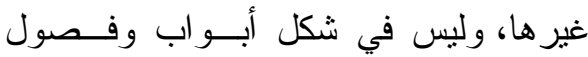

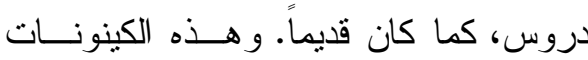

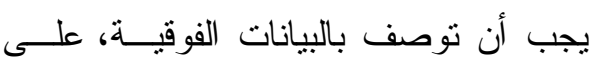

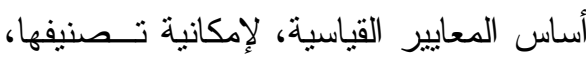

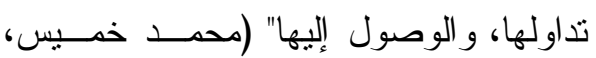
. (1) (1) r. 10 البيئة لابد أن يكون النظام نفسه قادراً على تمثيل الدور الهام من أجل تكييف بيئـــة

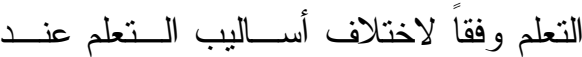

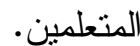


في البيئة التعليمية أمر ضــروري وبيئـات التعلم التكيفية نوفر أنظمة لتحقيق ذلك. r/l خصائص بيئة التعلم التكيفية:

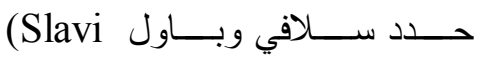

Stoyanov and Paul 2004,p.46(47خصائص بيئة التعلم التكيفية فيما يلى:

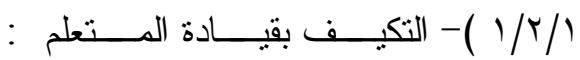
Learner-led adaptation أن يكون المتعلم قادرًا علــى العثـــور على ما يريد أن يتعلمه و الطريقة التي لدي

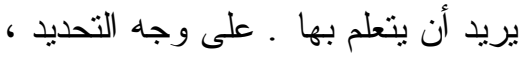

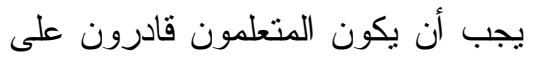

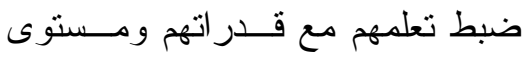
المعرفة السابقة و أسلوب التعلم. و أثنار (Stoyanov, 2001) عرض المحتوى على مستويات مختلفة من الصعوبة ضمن تـشكيلة كائنــات تعليمية مختلفة متل معلومات الخلفية ،

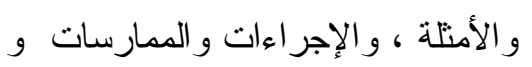
يكون للمتعلمين كامل الحرية فــي أن والن

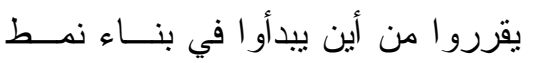

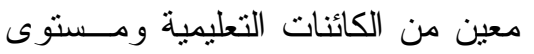
المحتوى. : Learner-regulated studying تمنح المتعلم التحكم في التعلم أي أنـــه

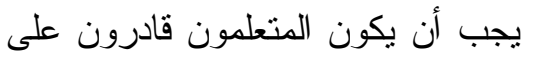

تعليمية ومستويات من الكفاءة و احتياجـات تعلم ومسنويات تحفيز منتشابهة

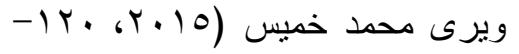

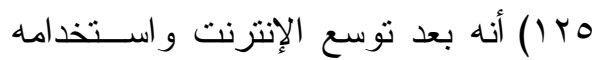
في التعليم، ظهرت بيئات تعليمية ذكية، تقدم

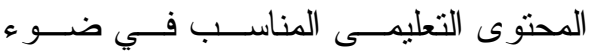
المعارف السابقة للمتعلمين، وذلك بناءا على النظريات و المداخل التعليمية، وذلك لتــوفير

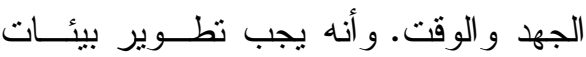
ونظم تعليم إلكترونية جديدة وخاصة محتوى التعلم التكيفي و الأكي، وبيئات التعلم التكيفية و الأكية، ويؤكد أن بحوث تكنولوجيا التعليم

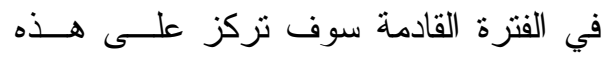
البيئات، حيث يكون كـلـل محتــوى الــتعلم الإلكتروني تكيفياً وذكيا، وكذلك بياناته.

\section{1/1 مفهوم بيئة التعلم التكيفية:}

Pavlov \& يعرف "بفلوف و يانيفا"

"التعلم التكيفـي" بأنـــــ (Paneva, 2006)

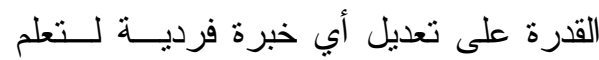
الطالب كطريقة للحصول على المعلومات من خلال أدائه المهام أو التقييمات المطلوبة.

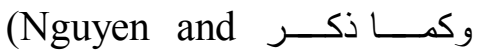
(Do,2008) فإن بيئة التعلم هي بنية معقدة

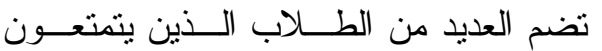
بخصائص مختلفة . فهـــ يختلفــون بـــنيا وذهنيا ، و كذلك أيضا تختلف تفـضيلاتهم . وبالتالي ، فإن التكيف مع هذه الاختلافــات 
: System administration

and

management

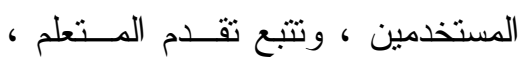

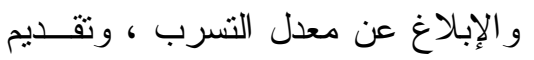

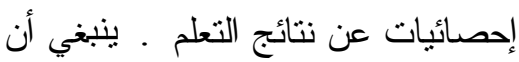

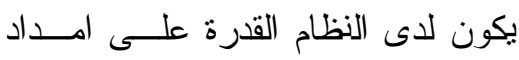

القائمين على الادارة بنظرة عامة عن

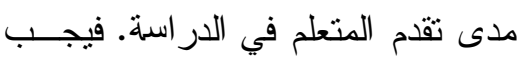

أن يكون لدى المؤسسات التي تــوفر لتون

التعليم الإكتروني القدرة على التصديق

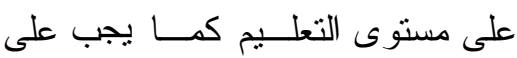

مديري النظام نقديم "مكتب دعم" عالي

$$
\text { الجودة مليز }
$$

: Technical المعايير الفنية ( V/T/

standards

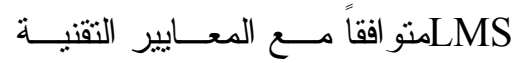

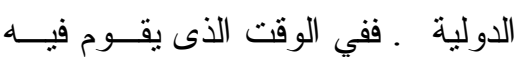
بتخزين ملفــات المتعلهـين و و-port

folios يجــب أن يــضمن الأمــن

و الخصوصية و الـسرية . حبــث ان

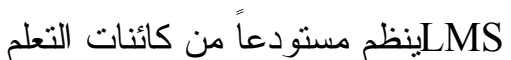

كبيانات وصفية ـو و هنالك اقتر اح مثثر كانير

للاهتمام ألا و هو تزويد المستخدمين

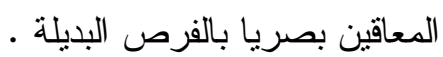

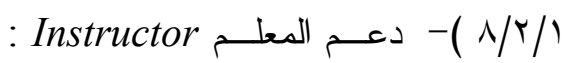

يقير ح الخبر اء نظــام دعـــupport
تحديد أهداف التعلم الخاصـــة بهـــم ،

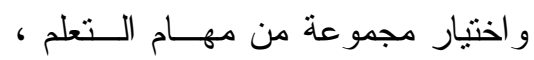

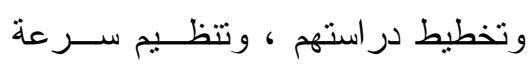

$$
\text { التعلم لديهم. }
$$

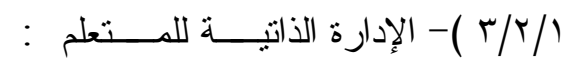

تشيرLearner self-management

إلى إمكانيات المتعلمين لإدارة الــتعلم الخاص بهم فيمكن أن بروا أين هم في الماني

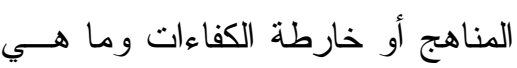
مهمة التعلم أو النشاط الذي يجب القيام

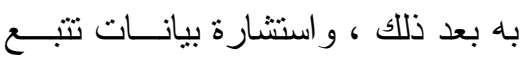

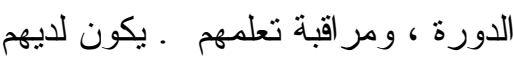
فرصة للتصفح المسبق و البحث عـن وند محتوى التعلم.

: Planning of تخطيط التعلم learning

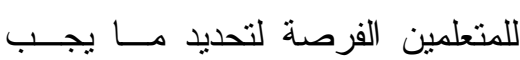

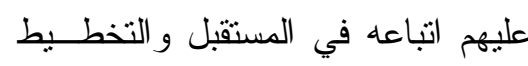
للتعلم على أساس التغذية الراجعة التي

$$
\text { يتلقونها. }
$$

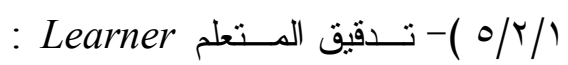

وauditing يكون لاى المتعلمين إمكانيات لاختبار

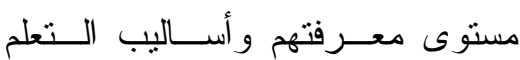

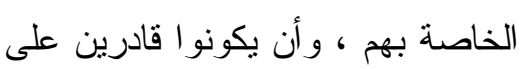

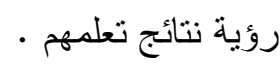


ليس فقط نتائج التعلم ،و لكن الاهداف

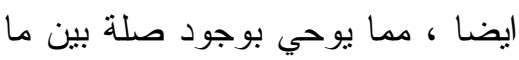

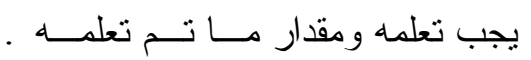
وأخيرًا ، يجب أن بسمح نظـــام الإدارة

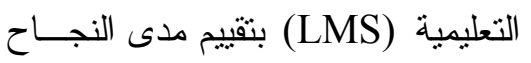
في التدريس.

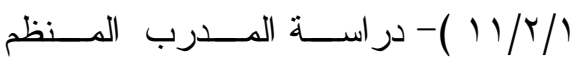
:Instructor-regulated studying

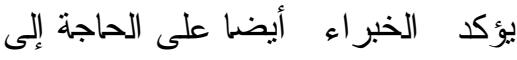
وجود مجموعة من المدربين لمر اقبــــة

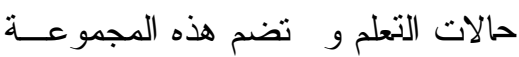
مدربين قادرين على تحديد مهام التعلم ، وتقديم التغذية الراجعة للمتعلهـين ،

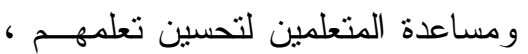
و وتقديم الإرشادات.

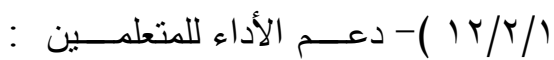

Performance support for learners دعم مضمن لأداء المتعلم و ينبغي أن

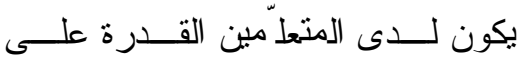
الوصول إلى الموارد و الحصول على لئى الدعم في الوقت المناسب ، و الكافي ، و الدعم على مستوى الحاجة

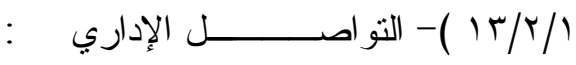
Administrative communication

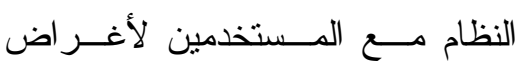

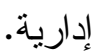

لمساعدة المعلمين في تحليل وتـصميم

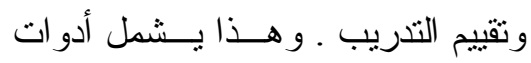

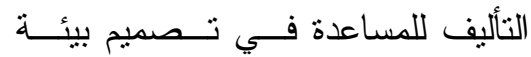

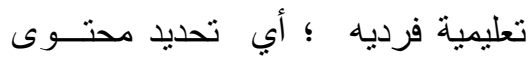

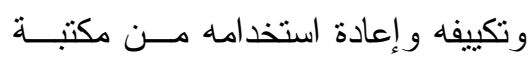
كائنات التعلم القابلة لإعادة الاستخدام. 9/ ا ( ) - التكيف بقيادة المدرب او المعلم Instructor-led adaptation حين يشدد الخبر اء على فرص التكيف

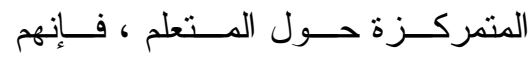
يشددون أيضًا على قدرة المعلمين على

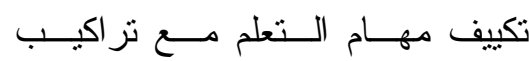
المتعلمين الثخصية. ينبغــي الـسماح

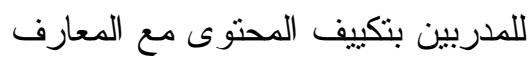

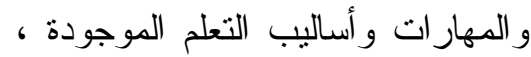
و ان يكون لــديهم إمكانيــات لتقــديم

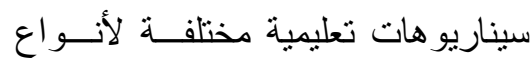
مختلفة من المتعلمين. Assessment إجر اء الثقييم : يشمل ذللك البيانات المتعلقـــة بتقبــيم

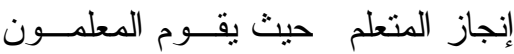
بتقييم معارف ومهار ات المتعلم (مسن

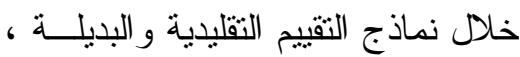
مثل تقييم الأقران و ملفـات الانجــاز الخاصة بـــالمتعلم) وكـــللك مر اقبـــة

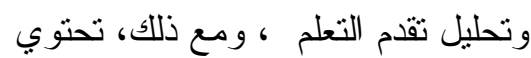

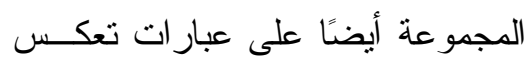


الذي من شأنه أن يساعد الطالب علـى

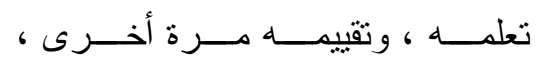

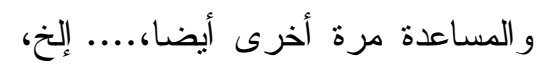

إلى أن يتحقق هدف تعليمي محدد . و

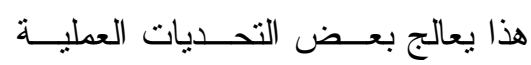

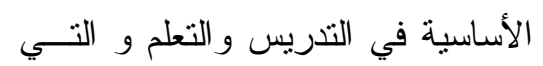

منها :

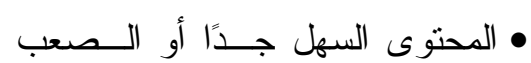

يعمل علــى تقليـلـل الحــافز لــدى

الطلاب و إصـابتهم بالملــلـل إذا كــان

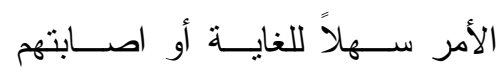

بالإحباط إذا كان صعباً للغاية .

• يأتي الطلاب إلى الصف الدراسي و

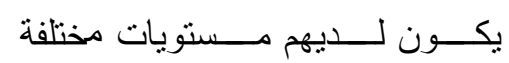

$$
\text { جو هريا من المعارف السابقة . }
$$

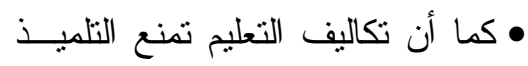

من تلقي الاهتمام من معلم خاص به نه

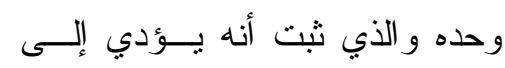

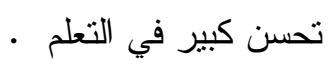

تزويد كل متعلم بظروف تعلــ/ (T/Y)

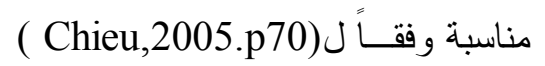

لتسهيل عملية بناء المعرفة الخاصــة

بهم.

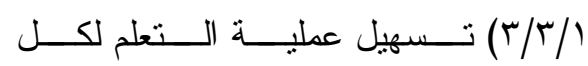

فرد (Martinez,2003) من خــال

توفير ظروف تعليميه مناسبة لهم.

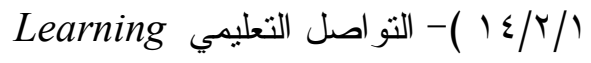

: يشير ذلك الـى :communication

التفاعل بــين المتعلمـين و المــدربين.

فيجب أن يدعم LMS التو اصل بــين

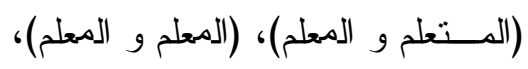

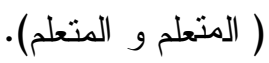

Collaboration التعاون

تشير الى انه يجب أن يكون المدربون

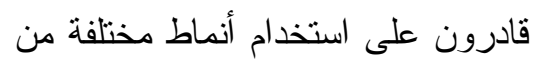

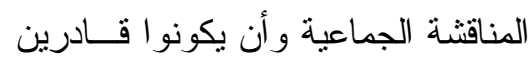

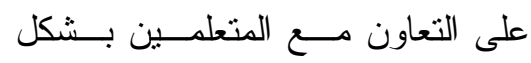

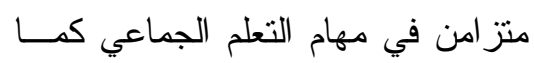

يؤكد الخبر اء أيضا على إمكانية التعلم

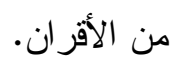

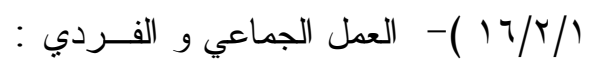

Group and individual work

توفر البيئة التكيفية الفرص للعمل فـى

$$
\text { مجموعات أو بشكل فردى. }
$$

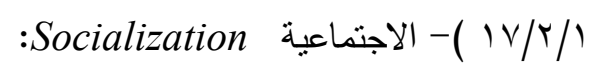

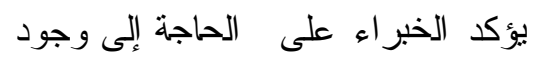

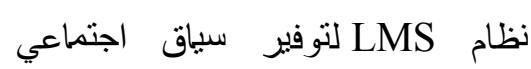

للاتعلم و هذا ما توفره البيئة التكيفية.

آم/ أهداف بيئات التعلم التكيفية:

(VanLehn K. , بري فـانلهن

2011 ان الهدف من بيئات الـتـعلم

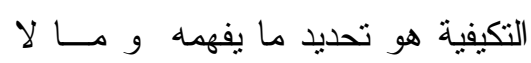

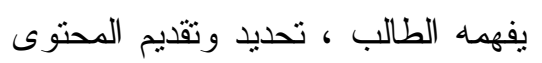


حسب احتباجات و اهتمامات و أهداف

و خلفية الطلاب Lee (2003)

1/

قيمه للموقف التعليمي من خلال تقــديم

المعلومات بطرق جذابه يمكن فهمها و

التي يتم وضعها فى سياقات ذات معنى و ذات صله وثيقه بالطالب

/

"التعلم الشخصي و الـــاتي" ،(محمــــ

عطيه خميس، ع ( . (Y، (Y-) .

/ / • (1/ )- جعل بيئات التعلم الإككترونيــة

اكثز ذكاءً، لأنها ستصبح قادرة علـى

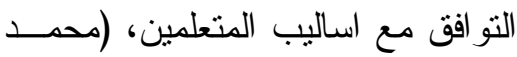

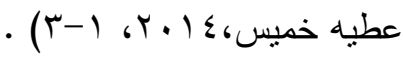

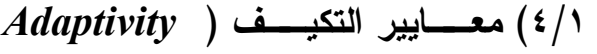
:(parameters

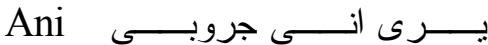

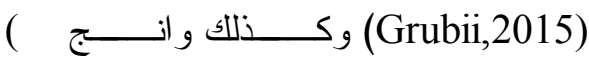

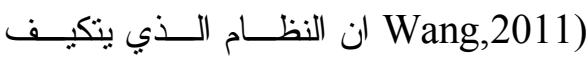

تلقائيا مع الطالب ، استتادا إلى افتر اضـــاته عن الطالب ، يشار إلىه على أنـــه نظــام

تكيفي. بمعنى آخر ، لا يمكن تسمية النظام

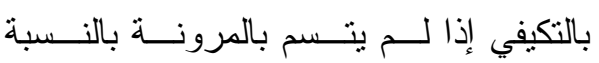
لاحتباجات محدده للطلاب. و لقد تم تطوير

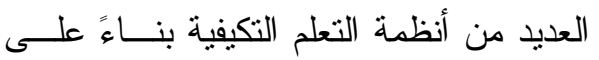
معايير مختلفة تمنثل خصـائص الطــلاب أو
( $1 /$ / تكييف المحتوى وفقاً للخـصائص

الفردية للمتعلمين، \& Brusilovsky ). Millan, 2007; Granić \& Nakic, 2010)

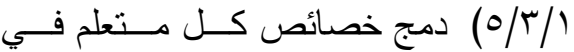

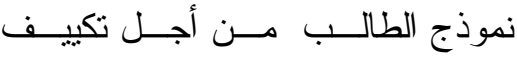
المحتوى وفقاً لاحتياجاتهم التعليمية. و ذلك بهدف تحسين كفاءة ونو اتج التعلم و كذللك ورضــــا المــتعلم ودافعيتـــه، (Deborah et al., 2014; Marković \& Jovanovic, 2012).

/ T/T/T) جعل التعلم الفردي قابل للتطــــير حيث أن بعض أنظمة التعلم التكيفيــة تثعامل مع تفـــيلات الطــلاب فــي التعلم، منل ما إذا كانت المعلومات تقدم في شكل نص أو صيغه ســماعيه ، أو إذا ما كانو ا يفضلون التعلم باسـتخدام در اســـات الحالــــة أو أدوات اختبــــار الوسائط المتعددة ،...إلــخخ. وبالتــالي يصبح لدى التعلم التكيفي القدرة علــى : الآتي) (VanLehn K. , 2011) • تقليل معدلات التسرب • يكون أكثر فعالية في تحقيق النتائج. • يكون أكثـــر كفـــاءة للطــلاب ، و يساعدهم على تحقيق النتائج بــشكل

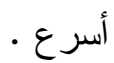

ضبط المحتهـوى المقـدم علــ/ 
نماذج مختلفة لأساليب التعلم. و قيل أنـــه إذا

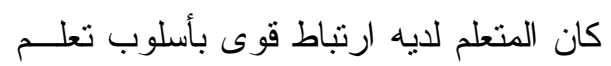

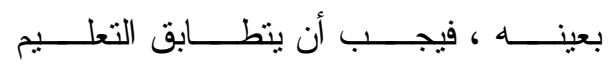

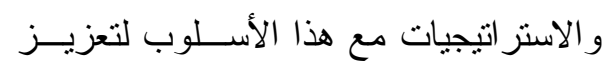
التعلم.

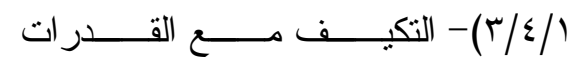

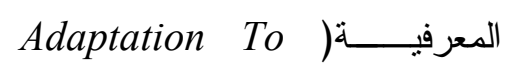

\section{(Cognitive Abilities}

وفقا لريــدينج ورينــر Riding and (Rayner, 1998) (Dimitrios,2008) المعرفي (CS) إلى طريقة الأفر اد في تتاول

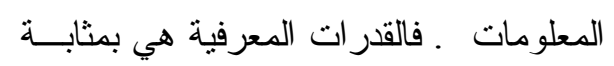

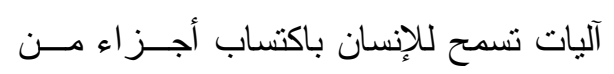

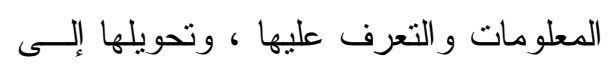

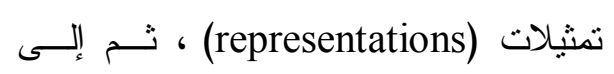

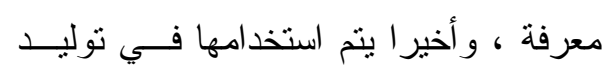

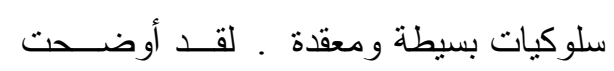

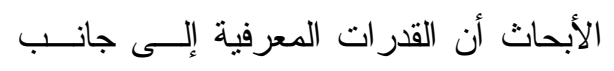

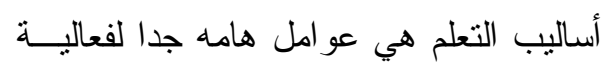

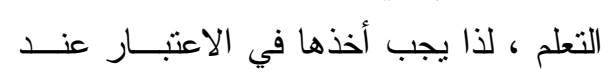

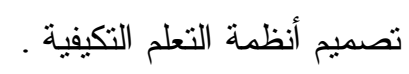

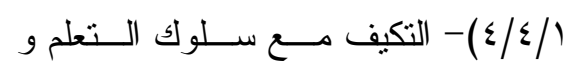

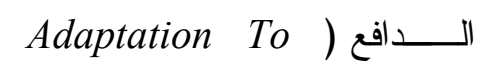
Learning Behavior And (Motivation يعد تعقب سلوك المتعلمين في الوقت
تفضيلاتهم بالإضافة إلى خصائص المحتوى التعليمي. و من أمتلة معايير التكيف :

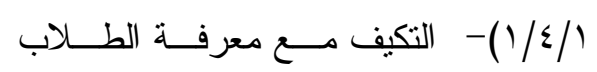
Adaptation To Student ) :(Knowledge

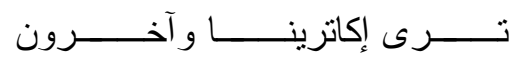

(Ekaterina,et,al,2005)

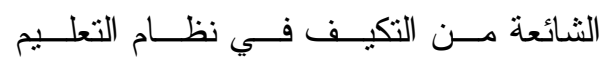

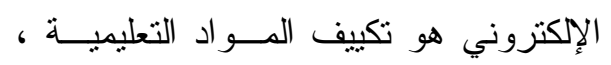
وتقديم العرض وفقا لمعرفة الطالــب فــي مجال الموضوع .الفكرة الأساسية هي أنــه فئه بالنسبة للطالب المتقدم ، يمكن للنظام تقــديم ملخص موجز للمادة و الارتباطات التـشعبية

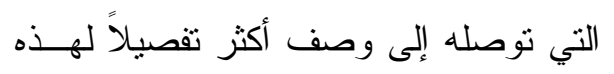

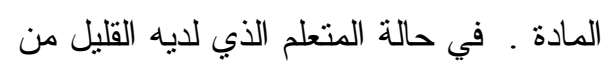
المعرفة في هذا المجال ، يمكن للنظام تقديم

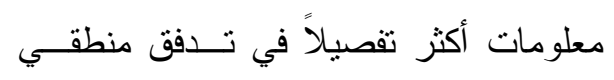
سلس. سلي

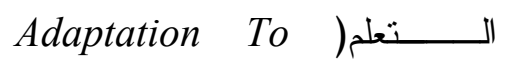
:(Learning Styles وأوضح فيلدر (Felder,2002 ) أن طريقة التكيف هذه تعتمد على فكــرة أنـــه يمكن للطالب أن يتعلم بشكل أكثر فاعلية إذا

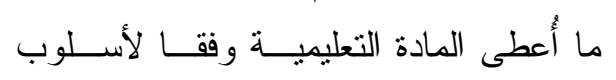
تعلمه . حيث أن مختلف الناس لايهم أساليب

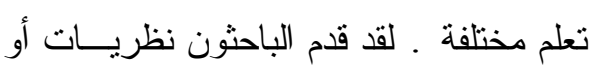


مبنى على أسلوب التعلم ومستوى المعرفـــة

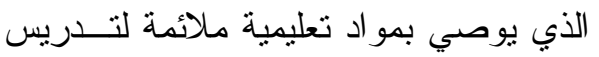

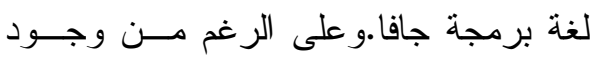
تقتيــات تكيــف مختلفـــة لأنظمــة الــتعلم الإككتروني ، إلا أن الفكرة الثائعة بالنـسبة لانسة

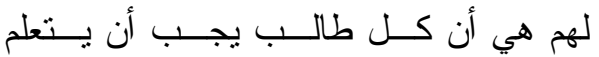
بالطريقة التي يفـضـلها ، ويجــبـ أن يــنت

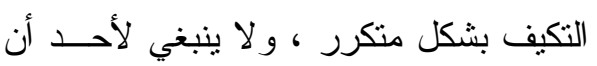

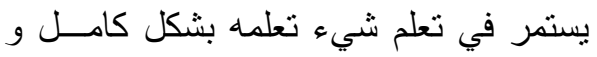

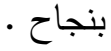
ثانياً: أنماط الدعم في بيئة التعلم التكيفيــة

(EPSS) ينتاول هذا المحسـور أنـــاط الـــدعم الداخلي و الخارجي و العرضي فــى بيئــات

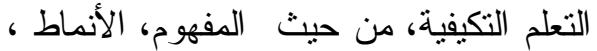

وفقاً لدباغ وكيتسانتس . Dabbagh ) وفيان

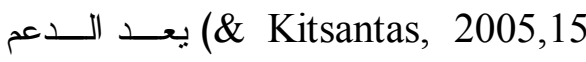
الالكتروني آلية فعالة في مساعدة الطـــلاب

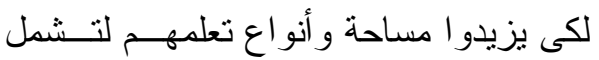

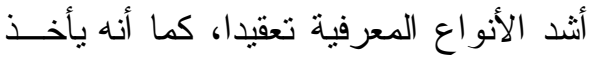
أثنكالاً عديدة وطرق متتوعة تساعد الطالب على الوصول إلى أعلـى مـستوى مــن الاستيعاب للمحتوي المقدم لله، مثل امـــداده

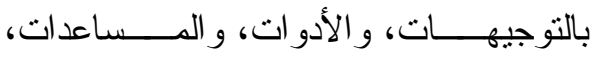

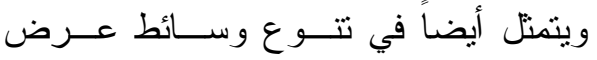

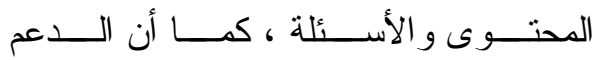
الإلكتروني يعد من عناصر التصميم الأولى
الفعلي لهو بمثابة مهمة كبيرة للغاية ـ فقـي عملها ، تعالج (Conlan, 2002) مــشكلة كيف يستطيع نظام تفاعلي مر اقبـــة حالـــة

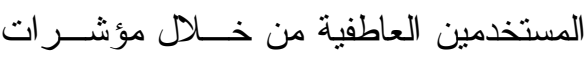

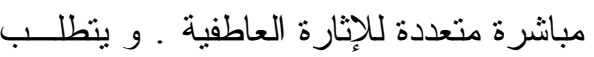

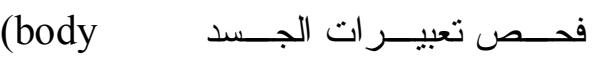
expressions) خاصة ـ ـ و لقد نم تطبيق نظام المر اقبة هــــا على ألعاب تعليمية تعتمد على الكمبيوتر بدلاً من المزيد من المعلمــين التقليــيين الــذين يعتمدون علـــى الكمبيــوتز ، حيـــث يميـلـل المستوى الأول إلى نوليد مستوى أعلى من لئن مشاركة الطلاب العاطفية

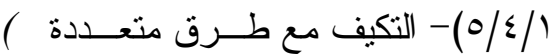
Adapting To Multiple Methods)

أنثــار كلاســنجا (Klasnja,2011) إلى انه يوجد أيضـا عدد من أنظمــة الــتعلم

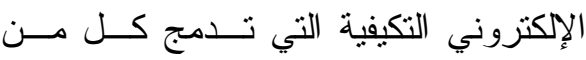
أسلوب التعلم ومستوى المعرفة كخـصـائص للمتعلم ضمن عملية التكيف. فعلـى ســبيل المثال ، تعدMASPLANG و واحدة مسن الرواد ، حيث تجمع بين أسلوب التعلم القائم

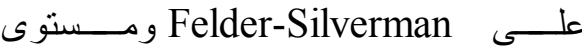

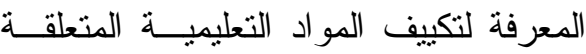
بدورة الثبكات الحاسوبية ـولعل أحد أمنلـــة الأنظمة الحديثة الناجحة هو نظام بروتوس Protus 
اتخاذ القرار بشأن اســتيفاء الأداء)، نظـــام

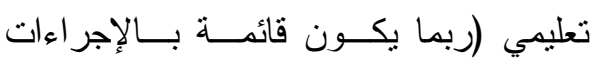

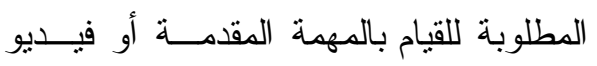

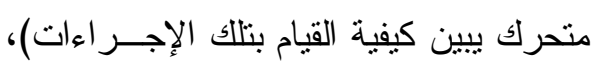

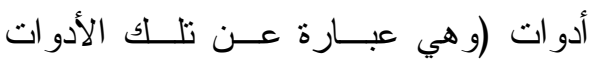
و البر امج التي يــــتخدمها المـــؤدي للقيــام بالمهية المطلوبة).

بينما أثنار (Barker, et al., 2007) أن نظم دعم الاداء تتضمن العناصر الآتية: قاعد بيانات (نظام كمبيوتر من أجل تخزين و استرجاع البيانات التي تخص النظام والتي تقوم على استخدام لغة التــساؤل البنائيــة)، نظام المساعد (و الغــرض منـــه ســـهولة وصول المــؤدي للمعلومــات المنـشـودة و الموجودة في قاعدة البيانات وذللك من خلال

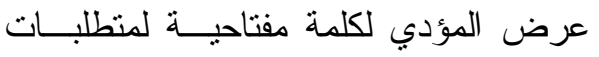

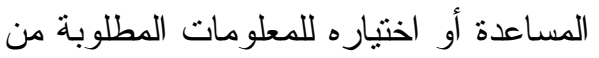
محتويات قائمة المساعدة المعروضة أمامـــهـ على الثانشة)، نظام الناصح (يوفر النصيحة

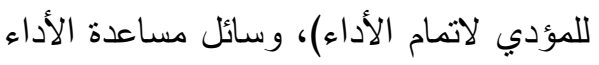

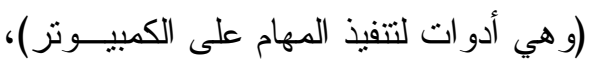

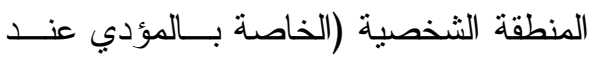
تسجيل دخول للأداء في ذلك النظــام فيــتم تسجيل تجوله خلال صفحات النظام وزمسـن دخوله وخروجه وتاريخ دخوله.
في بيئات التعلم الثخصية، حيــث تتطلــبـ بيئات التعلم الثخصية تضمين وتصميم دعم تعليمي يكون بمثابة مكون أساسي في عملية التعلم، حيث أم الدعم ضــروري كوســيلة لتقديم المساعدة للطلاب في عملية الــتعلم و دوري ذللك لبناء المعرفة في بيئة الــتعلم المنــصبة على الطالب. - مفهوم نظم دعم الأداء الإكتروني:

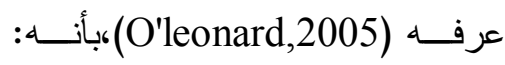

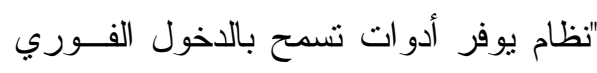

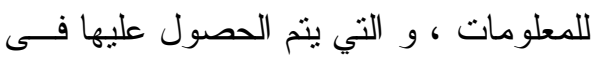
لحظة الاحتياج إليها".

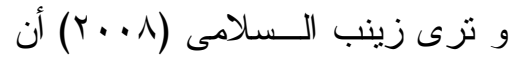

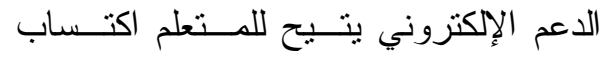

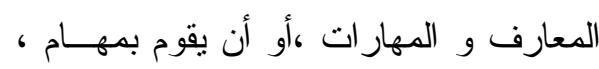

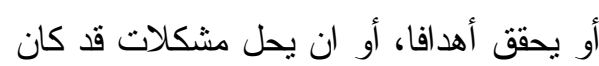

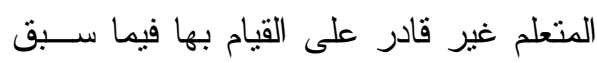
دون هذا الدعم ". مكونات نظم دعم الأداء الإكتروني: نظر اً لتعدد الآر اء بشأن تعريفات نظم

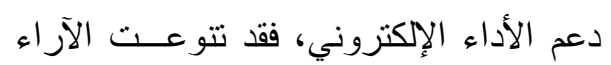
حول مكوناتها، فمن وجهة نظر جوستافسن (Gustafson, 2000) أربعة مكونات أساسية وهي: قاعدة بيانـات (مخزن للمعلومات التي يمكن الوصول إليها

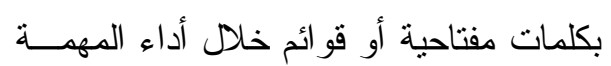

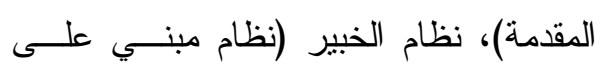
الكمبيوتز ينافس قدرة الخبير البـشري فـي لـي 
بشكل استر اتيجي داخل البرنــامج. يمكـن للمستخدم الحصول على المساعدة من خلال لتل النقر على هذه الأيقونة ، ولكن لايه خيـار

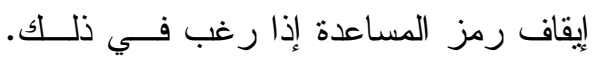

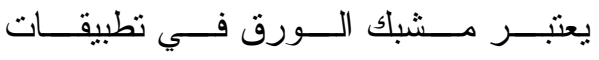
Microsoft Office

$$
\begin{aligned}
& \text {.(Gery, 1995) } \\
& \text { (ץ) الدعم الخارجي: }
\end{aligned}
$$

يكون الدعم الخارجي خارجيًا تماهًا

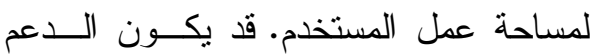
الخارجي أو لا يكون بولاسطة الكمبيوتر •و

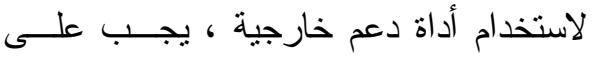
المؤدي أن يكسر تدفق الأداء ويترك بيئـــة

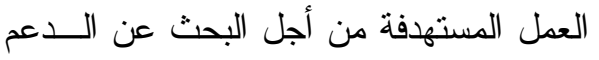
المناسب وتحديد موقعه. و من أمنتلة أدوات الدعم الخارجية : أدوات مساعدة الوظيفــة

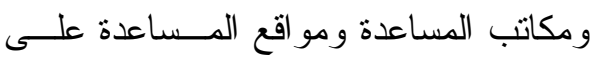

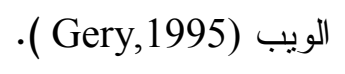$$
\text { مميزات الاعم الإكتروني: }
$$

حدد (Beale,I.L.,2005) مميزات الدعم

$$
\text { الإكتروني كالآتي: }
$$

ل يخفض الدعم من عدد الخطوات لحل مشكلة ما ، و من ثم يقلل من احساس عن عند

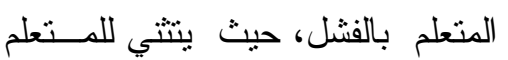
اتمام مهوته المطلوبـــة مــن خـــلهل الاستقادة من الدعم المتوفر .
مستويات التكامل لأنظمة الاعم (EPSS)

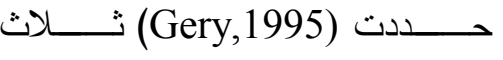
مستويات أو أنواع من التكامل لأنظمة الدعم .EPSS (1) - (الدعم الاخلي: الدعم الداخلي متأصل فـــي واجهــة البرنامج المستهذف. و يهذف الدعم الداخلي إلى تقديم الدعم للمستخدم دون أن يكــون

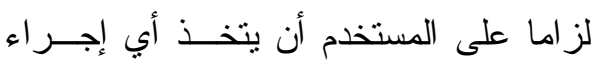
بعينه (Huff, 2007). و عندما نكون هنالك مستويات عالية من الدعم الجوهري ، فليس من المهم ان يكــون النــاس علــى در ايـــة

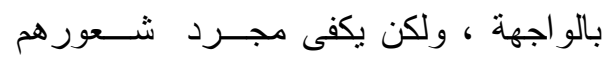
بأنهم يقومون بعملهم (Gery,1995). و يتو يتم تضمين الدعم الداخلي مباشرة في برنــامج العمل المستهدف ، و يتم تــوفير المسساعدة

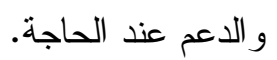

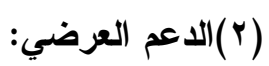

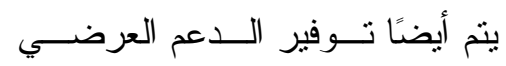

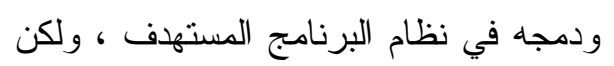
محتوى الدعم نفسه ينو اجد في موقع خــارج

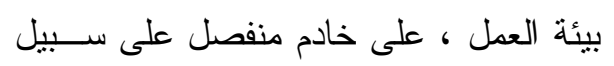

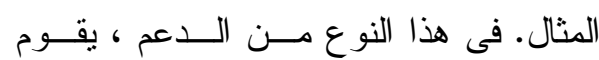
المستخدم بإيقاف الأداء الفعلي ، ولكنه يظل هن

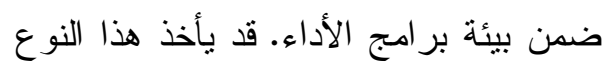

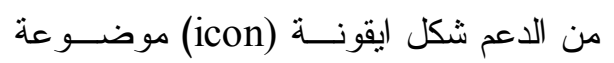




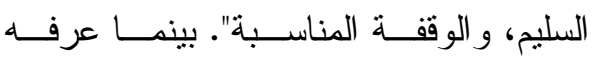

بأنه "قـــدرة الطالـــب (Feng,2007,p.25)

على التعبير عن نفسه في البيئـــة التعليميـــة

$$
\text { و الاجتماعية". }
$$

أهداف مهارة التحدث باللغة الإنجليزية:

تأتي مهارة التحدث في المرنبة الثانية

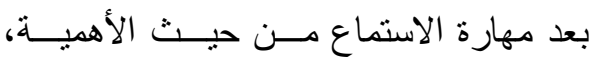

و هنالك علاقة وثيقة بين مهارتي الاســتماع بهاع

و التحدث و الني لا يمكن تدريسها بمعزل عن بهن

بعضها، و ذكر (Abu- Gharrah,2005)

بعضاً من أهداف مهارة التحدث على النحو

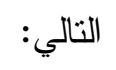

• تعريف الطلاب بالخــصائص اللغويــة غير اللفظية للاتصال.

• تمكين الطلاب من ممارســة التحــدث

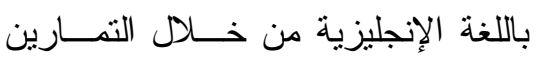

$$
\text { الثفهية داخل الفصل. }
$$

• إنر الك الطلاب في التفاعلات الــصفية

من خلال استخدام التقنيـات الـشفهية

$$
\text { وممارستها. }
$$

• تدريب الطلاب علـى تتميــة عــادات

استخدام الأعضاء الصوتية أثناء التحدث

باللغة الإنجليزية.

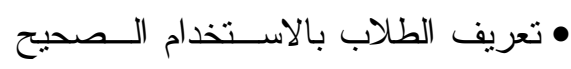

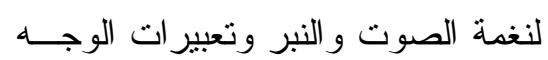

لنقل الرسالة المتحدث عنها. $\checkmark$

الإككتروني مدخلا للتعلم الفردي،حيث

يتم تصميمه بحيث ير اعى حاجـات

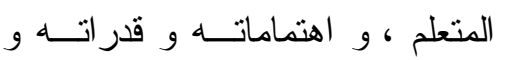

$$
\text { اساليب تعلمه . }
$$

ل يتيح له التدريب و الممارسة و يقـدم

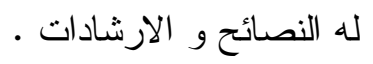

ل يزود الدعم ، و ينظم حل المشكلات،

و يقلل من عدد الاخطاء التي ترتكب

أثناء التعلم ،فدعم المتعلم بالتوجيهات

و الارشادات التي تذكره بــالخطو ات بات

التي يجب أن يتخذها ،فهـو يـسـاعد

على تخطى و تجاوز العقبات .

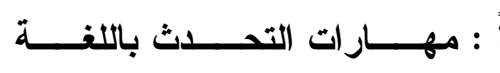

\section{الانجليزية:Speaking Skills}

مفهوم التحدث:

تعددت التعريفات لمفهوم التحدث، فقد

عرفه نبيل عبد الهادي ؛ و عبد العزيز أبــو

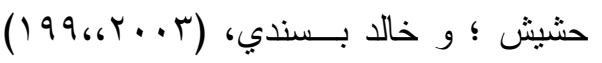

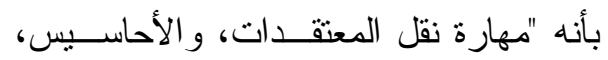

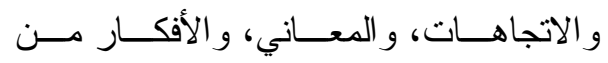

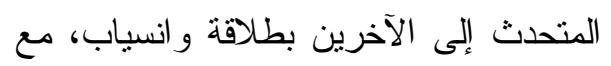

$$
\text { صحة في التعبير وسلامة في الأداء". }
$$

و عرفته (فاطمة عبد العال شــريف

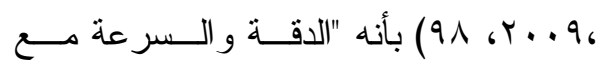

مر اعاة الطلاقة، و الصوت المعبر، و النطـــن 
r- استراتيجيات التفاعل:وتتضمن التمثيل

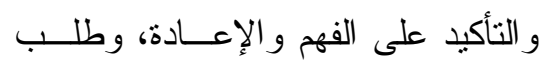

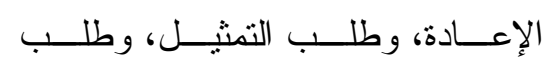
المساعدة حيال الكلمات الصعبة.

إجرايوات البحث:

النموذج المقترح لبيئة التعلم التكيفية: بعد الاطلاع علي نماذج مشتقة مــن

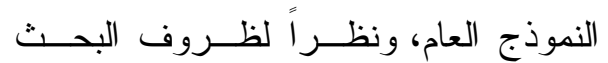

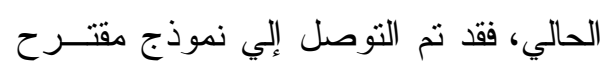

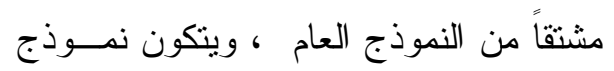
التصميم من المر احل التالية: 1 - مرحلة التصميم

ونتشمل هذه المرحلة الخطوات التالية:

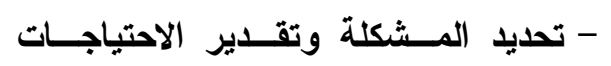
التعليمية من بيئة التعلم التكيفية : حددت مــشكلة البحـــث فـي كتهـرة

مصادر التعلم الإلكتروني المنـشورة علــي لإنـي

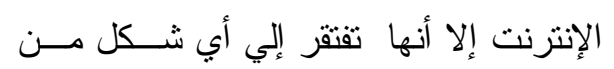

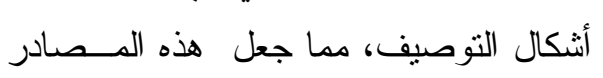

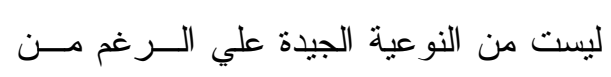

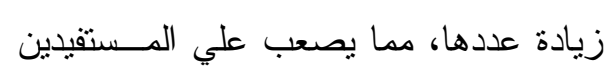

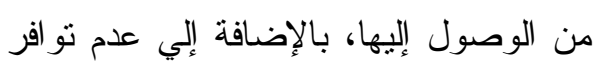

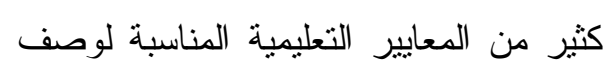
تلاك المصادر .

- تحديد الأهداف التعليمية لبيئــة الــتعلم التكيفية: تهدف بيئة التعلم التكيفية الي :
استر اتيجيات اكتساب اللغة:

يحدد كل مسن ( ) , Goh \& Burns)

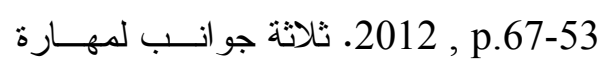

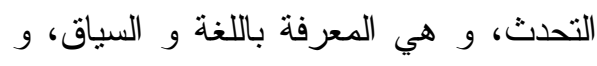

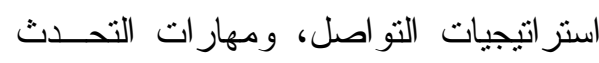

الأساسية. و تتضمن المعرفة باللغة و السياق:

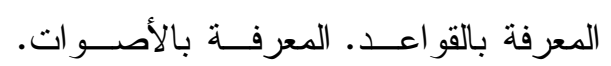

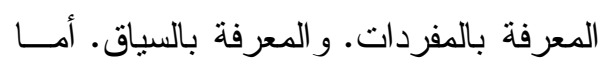
التو اصل فتتمتل في : الاصني

1 - الاستر اتيجيات المعرفية: وتعني إيجــاد

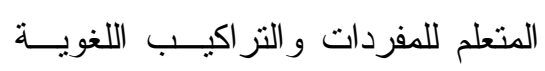
المناسبة للتعبير عن أفكار ه، كما تتضمن هذه الاستر انتيجيات ذكر كلمـــة بديلـــة

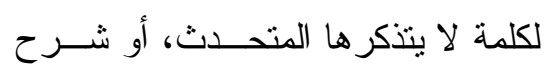

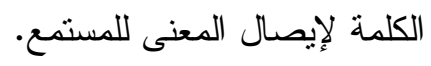

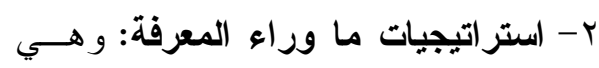

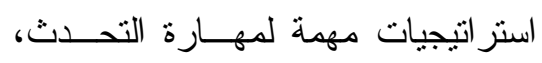

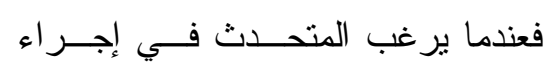

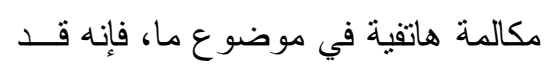

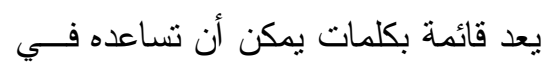

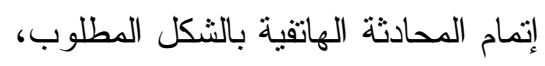

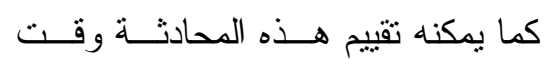

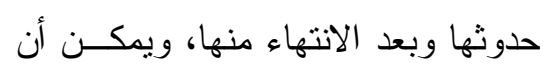

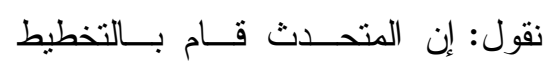

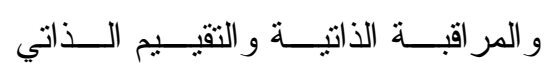

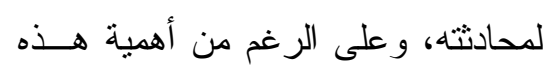

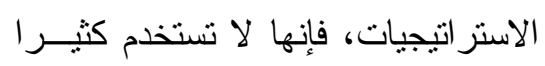
في المحادثات المباثرة. 
و الفروق الفردية بينه وبين غيره من

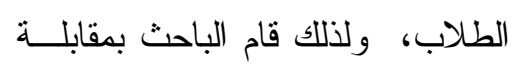

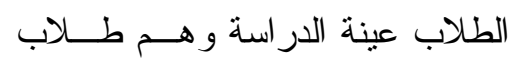

الثاني الثانوي بمدرسة تمي الامديــد

الثانوية لمعرفة خصائصهم وخبر اتهم

التعليمية وقدر اتهم المهنية و العقليــة

$$
\text { و النفسية. }
$$

- تحليل الموارد والقيــود المتاحسـة :

نظر ا لان تصميم و استخدام بيئة التعلم

التكيفية يتطلب التعامل مع المعلومات

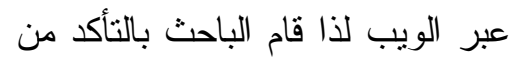

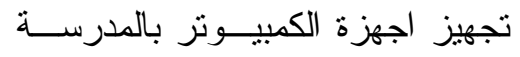

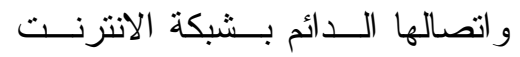

ليتمكن الطلاب الــذين لا يمنلكـــون

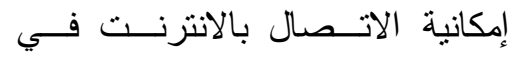

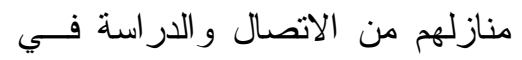

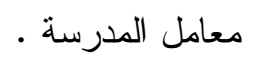

r- برحلة التطوير

- بناء وحدات التعلم (LO): نم بنــاء

وحدات التعلم في أثنكال متعددة منها

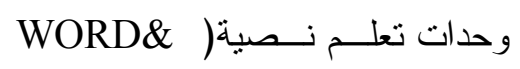

، ووحدات عروض تقديمية (PDF

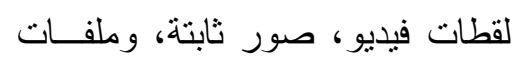

$$
\text { صوتية. }
$$

\section{- تصميم الخريطة الأسـيابية لبئـــة}

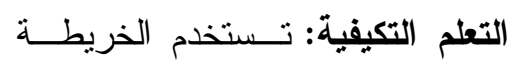

الانسيابية Flow Chart لإعداد رسم
1- تخزين واستذعاء المحتوى التعليمسى

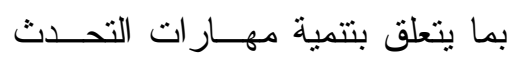

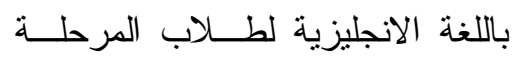

$$
\text { الثانوية. }
$$

r- تصنيف وتبويــب وترتنــب البيئــة

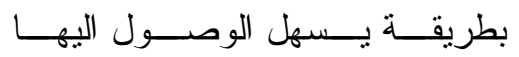

$$
\text { و استر اجعها. }
$$

ب- إتاحة استخدام بيئة التعلم التكيفية فــي

$$
\text { الوقت و المكان الذي يناسب الطلاب. }
$$

ع - تيسير الدخول لبيئة الــتعلم التكيفيــة

و الوصول الي وحدات محتو اها في

وقت سريع وباقل جهد من المستخدم.

- تحليل المهام التعليميــة المكونــــة

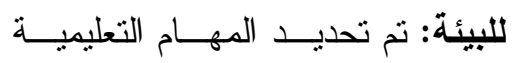

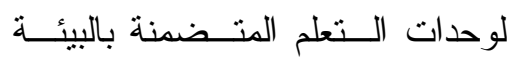

التكيفية من خلال مــصادر متعـددة

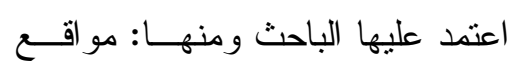

وصفحات الويب و المنتديات المهتمة

بتخصص تكنولوجيا التعليم و الـتـعلم

التكيفي، المر اجع و الكتب و الدوريات

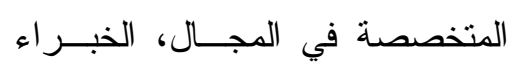

و المتخصصين .

- تحليل خصائص الطلاب المستفيدين

من المعمل الطالب هو المستقيد مـن

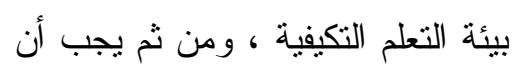

ير اعي حاجتـــه وميولـــه وقدر اتــه، 
- إنتاج بيئة التعلم التكيفية: نم في هذه

الخطوة برمجة محتوي بيئــة الــتعلم

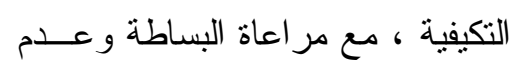

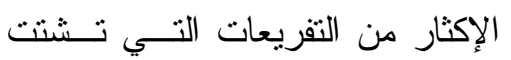

انتباه الطالب، وكذلك تم مر اعــاة ان

تكون صفحات محتوي البيئة مريحة

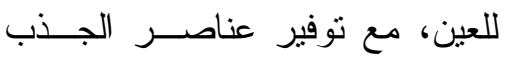

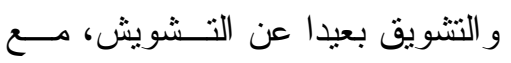

توفير عنصر الوحدة والتوازن بـين لونين

لون الصفحة ولون الخلفية

r- مرحلة التقديم: - مان

في هذه المرحلة قام الباحث بما يلي:

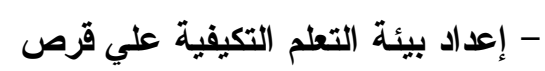

مدمج CD: تم إعداد البيئة التكبفيــة

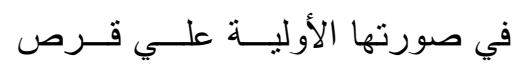

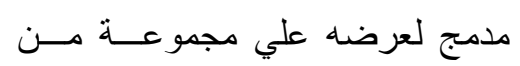

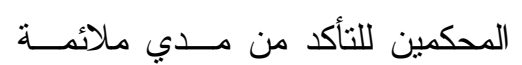

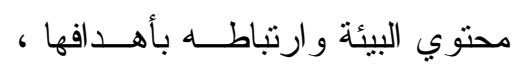

ومدي ملائمة عناصر محتوي البيئــة

$$
\text { في تقديم المحتوي. }
$$

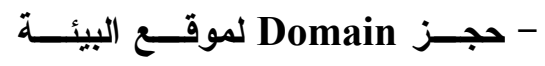

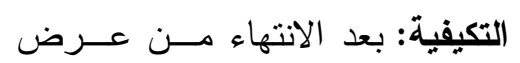

محتوي البيئة في صورته الأوليــة

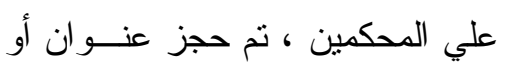

Domain

روعي عند اختيار عنوان موقع البيئة

$$
\text { أن يتسم بالبساطة و السهولة. }
$$

تخطيطي متكامل بالرموز و الأثــكال

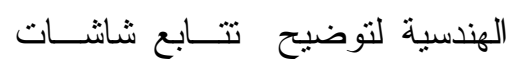

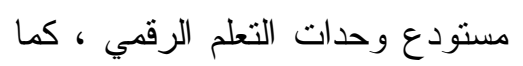

تعد وسيلة اتصال مع الآخرين للإلمام

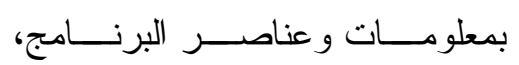

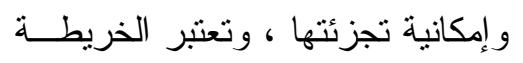

الانسيابية لمستودع وحــدات الـتـعلم

سجلا يمكن الرجوع إليه عند الحاجة

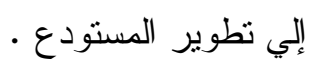

- تصميم أنماط الدعم ببيئــة الــتـلم التكيفية: تعد خطوة تصميم التفاعـل في مسنودع وحــدات الــتعلم مــن

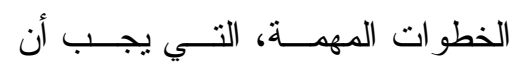
يوليهـــا المــصمم التعليمــي أهميــة خاصة، ويتتوع الدعم في المسستودع

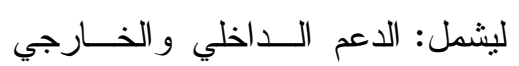

$$
\text { و العرضي. }
$$

- إعداد سيناريو لبيئة التعلم التكيفية.:

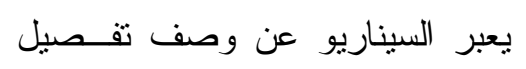
للشاثشات التي سيتم تــميمها ومهـا

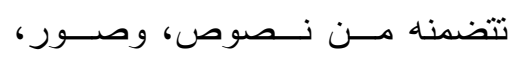

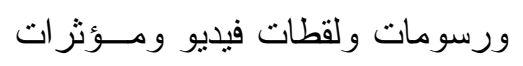

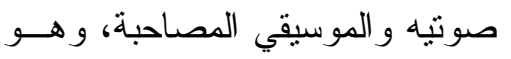
يعد مفتاح العمل وخريطة التنفيذ التي وليه ولهي تتيح للفكرة المطروحســة فـــي البيئسـة التكيفية التعلم أن تتفذ في شكل مرئي ومسموع. 
التحدث باللغة الإنجليزية لدي طلاب الــصف

$$
\text { الثاني الثانوي. }
$$

تحديد الهرف من الاختبــار: هـدف

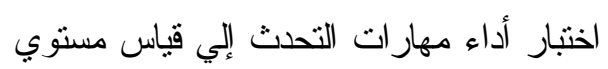

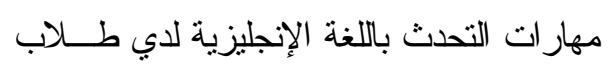

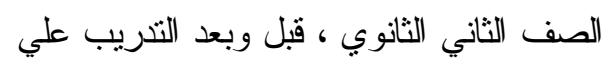

بيئة التعلم التكيفية القائمة علي انماط الــدعم الداخلي و الخارجي و العرضي.

1- تحديــــ نـــوع مفــردات الاختبـــار

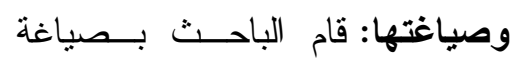

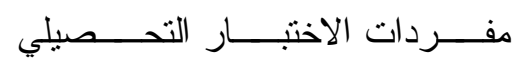

الموضوعي فــي صـــورة (اختبـار

شفهي مقترن بتسجيل للإجابة) كمــا

راع الباحث الثروط الواجب إنباعها

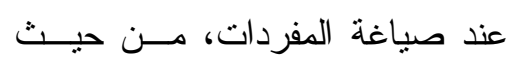

صياغتها بأسلوب سهل وبسيط يمكن

$$
\text { للطالب أن يفهمه بسهولة. }
$$

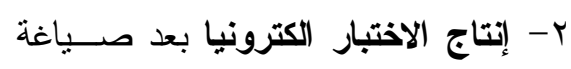

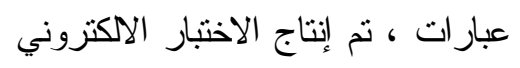

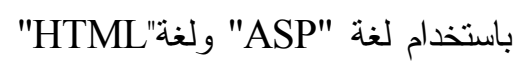

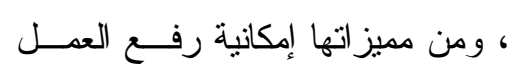

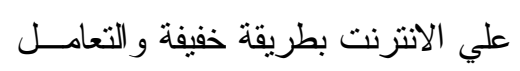

مع "DATA Base" و النعامــل مـــــ

عمل تقاعلي وإمكانية تسجيل البيانـات

$$
\text { و إظهار النتيجة. }
$$

r- وضع تعليمات الاختبار : تم وضــع

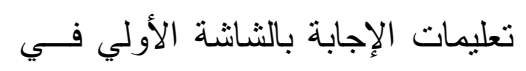

- الاتفاق مع احد شركات الاستــضـافة

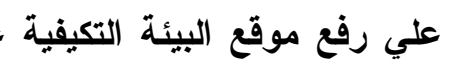

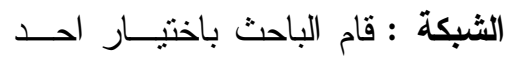

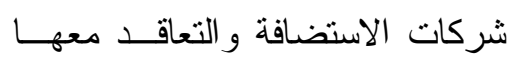

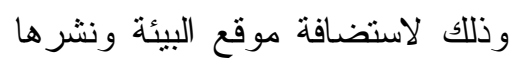

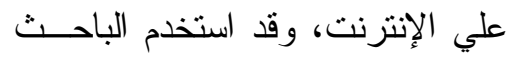

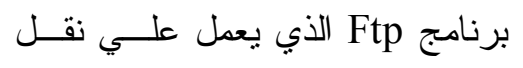
الملفات من جهاز الكمبيونز لتحميلها بعليا علي الإنترنت. - تجريب موقع البيئة علي الاتترنت.:

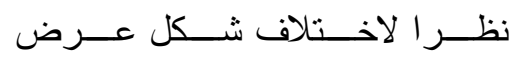

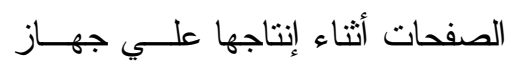
الحاســوب، عـن الـشكل الحقبقـي

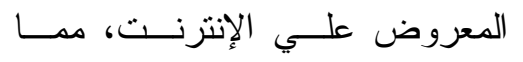
تتطلب إعادة فحص وتقييم البيئة فور الإنرن الانتهاء من تحميلها علي الإنترنت.

$$
\text { ع - مرحلة التقويم: }
$$

استهدفت هذه المرحلة قياس فاعليــة

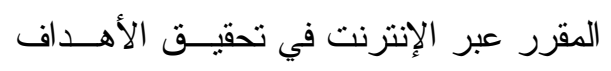

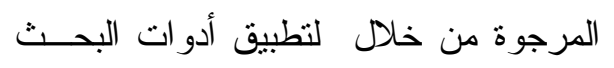

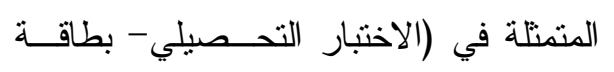
تحليل مهار ات التحدث). سادسا : التجريب الميداني للبحث:

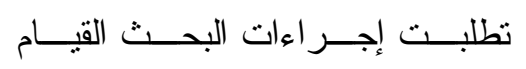

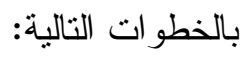

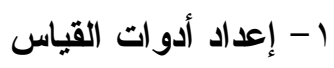
أولاً: الاختبار التحصيلي: أدوات التيان

وفي ضوء أهداف بيئة التعلم التكيفيــة ومحتو اها التعليمي نم إعداد وتصميم اختبــار

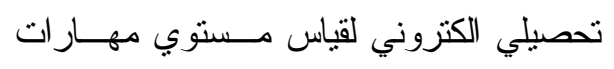




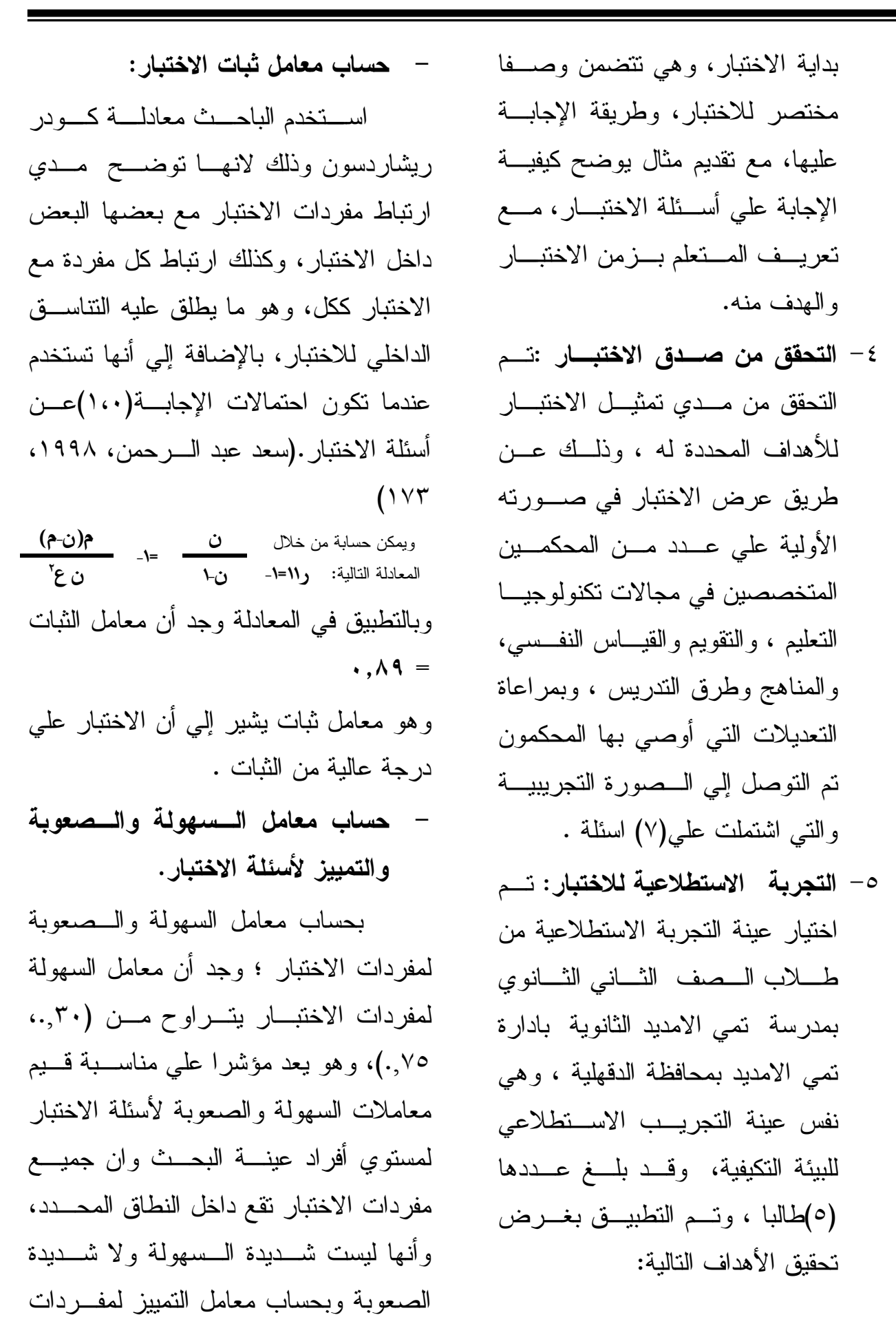


1 - تحديد الهُف من بناعها: اســتهدفت

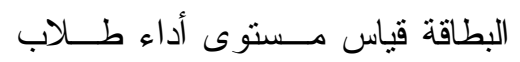

الصف الثاني الثانوي بمدرسة تمي لئي

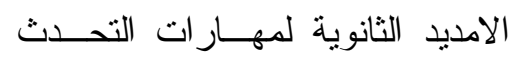

باللغة الاتجليزية.

r - تحديد أسلوب تـسجيل الملاحظــة:

وضع علامة ( ل ) ) أمام درجة الاداء

للمهارة بالبطاقة.

أ- وضع نظام تقدير الــدرجات: تـــ

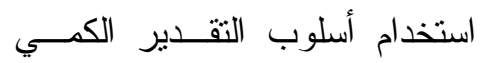

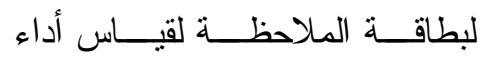

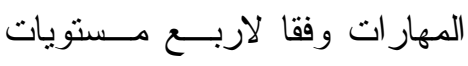

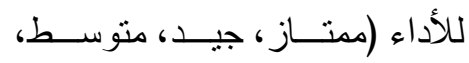

$$
\text { ضعيف). }
$$

وتمّ تحديد وتوزيع تلـــك الــدرجات

بالاستعانة ببعض الاحتمالات التــي قـدمها

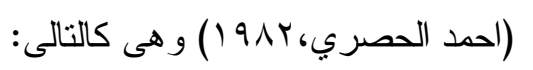

- إذا قام المتعلم بأداء المهارة بدقة عالية

وبدون أي أخطاء؛ يتم وضنع علامـــة

$$
\text { (لم) في المستوي(مثتاز ). }
$$

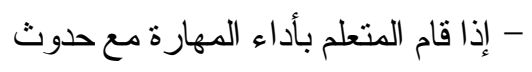

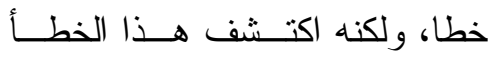

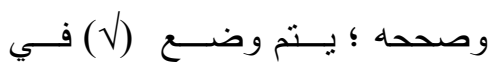

المستوي(جيد).

- إذا قام المتعلم بأداء المهارة مع حدوث ل

خطا، ولكنه اكتشف هذا الخطأ ، وقام

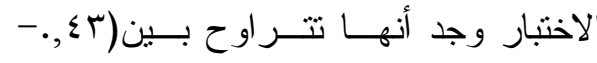

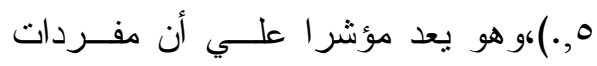

الاختبار ذات قدرة تمييزية مناسبة.

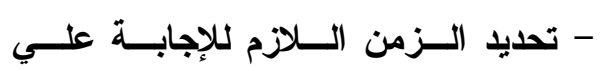
الاختبار :

نم حساب الزمن اللازم للإجابة علي

مفردات الاختبار، وذلك عن طريق تـسجيل

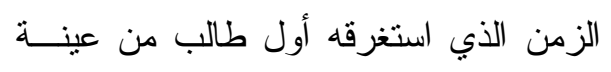

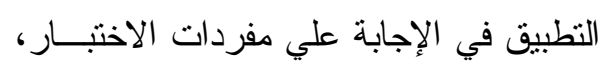

وكذلك الزمن الذي استغرقه آخر طالب من الإنية

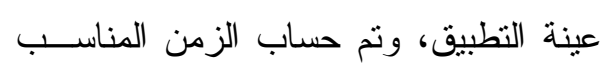

للإجابة علي مفردات الاختبار ، وذلك بإيجاد

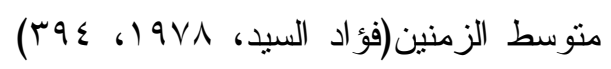

فكان في حدود · ب دقيقة.

- إعداد الصورة النهائية للاختبار:

بعد إجر اء التعديلات علي الاختبــار

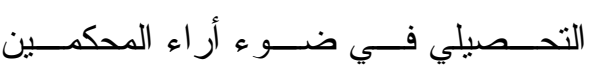

وتوجيهاتهم، ونتائح التجربة الاسـتطلاعية

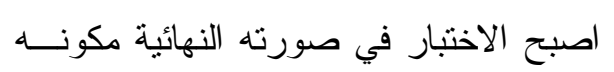

$$
\text { من ( 0) اسئلة . }
$$

r - إعداد بطاقة تحليل لمهارات التحـدث

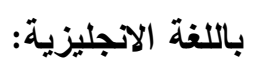

الملاحظة أســلوب بــنت بواســـنه

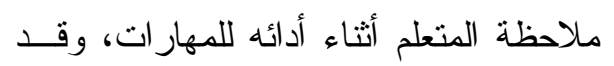

اتبع الباحث الإجراءات التالية لإعداد هــــهـ البطاقة : 
التعليم) بهدف التأكد من دقــة التعليمـات، وسلامة الصياغة الإجر ائية لمفردات البطاقة

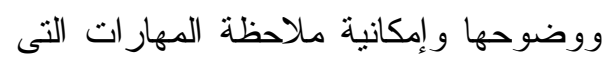
تتضنها، و إبداء أى تعديلات برونها. حساب ثبات البطاقة: تم حساب معامل الثبــات (ألفــــامه) كرونباخ، وذلك باستخدام مجموعة البـــر امج

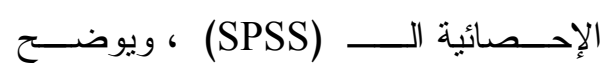

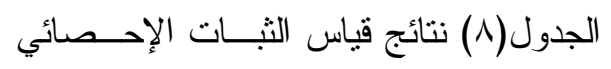
وجد ان معامل ارتفاع معامل ثبات بطاقـــة

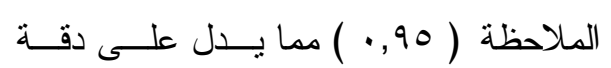

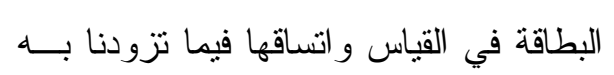
من معلومات عن مستوي أداء أفر اد عينة. تتفيذ التجربة الأساسية:بعد الانتهاء

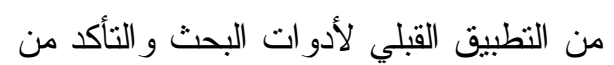

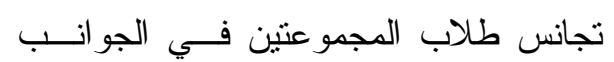
المعرفية و الأدائية، نم تتفيذ التجربة الأساسية

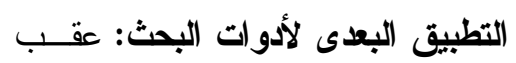

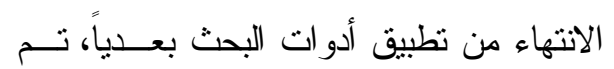

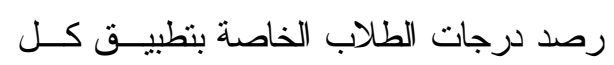

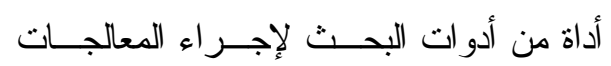

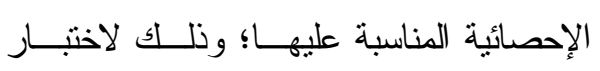

$$
\text { صحة الفروض و الإجابة عن اسئلة البحث. }
$$

\section{نتائج اختبار فروض البحث} 1- اختبار صحة الفرض الاول:

قام الباحث باســتخدام اختبــار (ت) وذللك للتحقق من صحة هذا الفرض و الـــي
المعلم بتصحيحه له؛ يتم وضع (ل) في المستوي(متوسط).

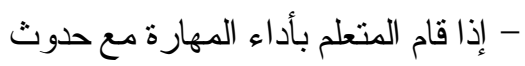
خطا، ولكنه المعلم هو الذى اكتشف بادف هذا الخطأ ، وقام المعلم بتصحيحه له؛

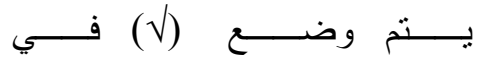

$$
\begin{aligned}
& \text { المستوي(ضعيف). }
\end{aligned}
$$

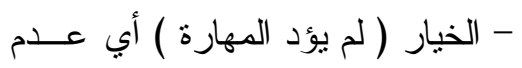

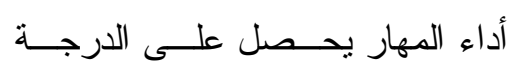
ويتمُ تسجيل أداء الطالب للمهــار ات

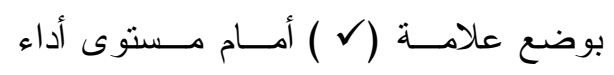
المهارة، وبتجميع هذه الدرجات يتم الحصول

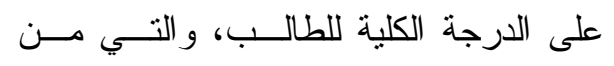

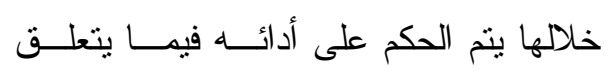

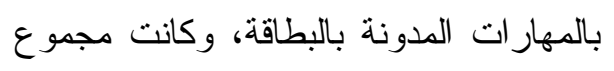
درجات بطاقة الملاحظة في صورتها الاولية يساوى ( • • ) درجة.

r- ضبط بطاقة الملاحظة: يقصد بعملية

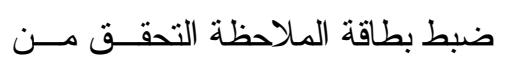

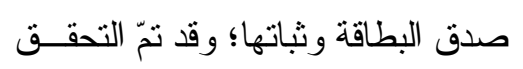
من ذللك وفق الإجر اءات التالية: أ- التحقق من صدق البطاقة: وللتحقق من ذلك؛ تم عرض البطاقة على مجمو عة من السادة المحكمين و الخبر اء

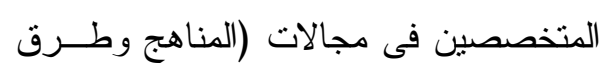

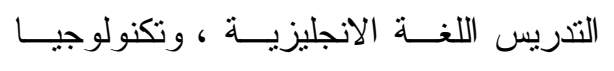




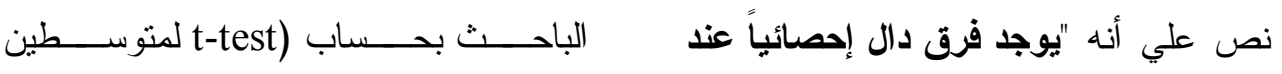

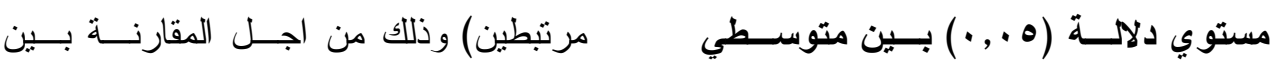

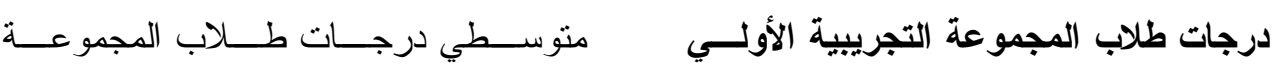

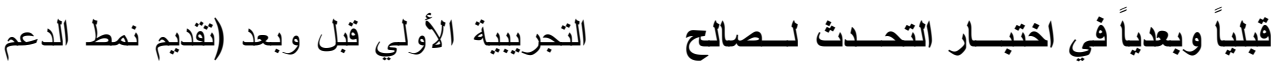

$$
\text { التطبيق البعدي" كما في الجدول الآتي: الداخلي) علي اختبار التحدث. }
$$

جدول (ץ) يوضح المتوسطات والآحر افات المعياريه وقيمة ت المحسوبة ودلالتها الإحصائية

\begin{tabular}{|c|c|c|c|c|c|c|c|}
\hline 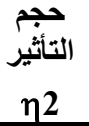 & مستوي & قيمة "ت & الحرية & الالحعراف & المتوسط & التطبيق & المستوي \\
\hline \multirow{2}{*}{ - ,99 } & \multirow{2}{*}{ دالة عند } & \multirow{2}{*}{$\checkmark \leqslant, \Gamma \leqslant$} & \multirow{2}{*}{ rq } & $r, r V$ & ד, & القبلي & \multirow{2}{*}{ ختبار التحدث } \\
\hline & & & & $1, \cdot 1$. & $r \wedge, \cdot r$ & البعدي & \\
\hline
\end{tabular}
بين درجات المجموعة التجريبية الاولي في التطبيقين القبلي والبعدي لاختبار التحلث

يتضح من الجدول السابق أن قيمسـة و الأداء البعدي اختلاف معنوي أي لا يرجع

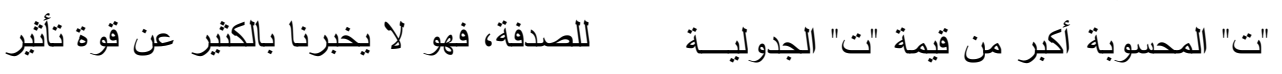

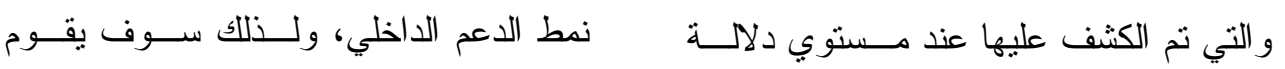

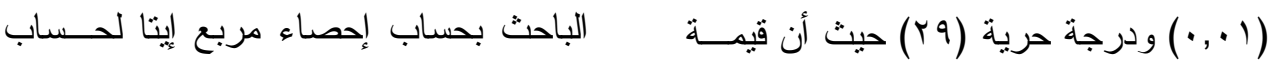

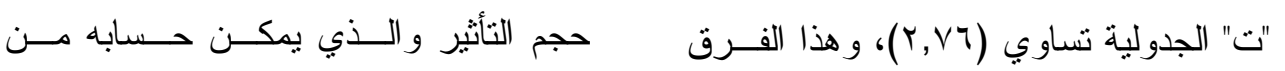

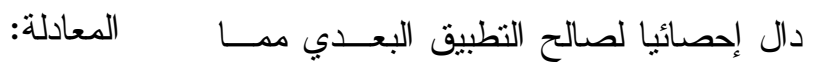
$\mathrm{Eta}^{2}=\frac{t 2}{t 2+(N-1)}$

ويلاحظ الباحث من الجدول ( 2 ) أن

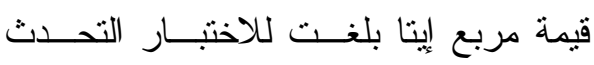

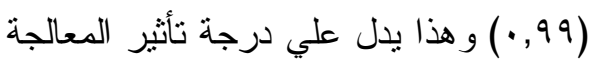
يشير إلي وجود فرق ذو دلالة إحصائياً بين

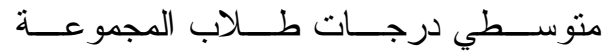

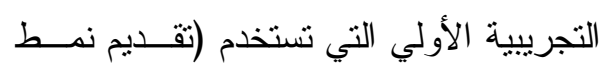

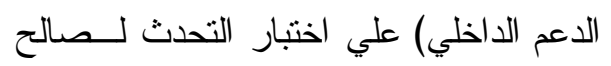

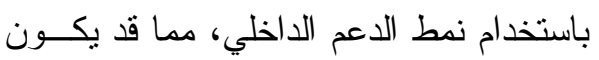
التطبيق البعدي.

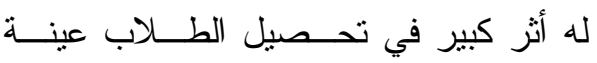
وبالرغم مــن أن نتيجـــة الاختبـــار

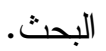

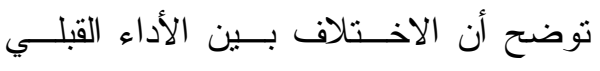


مستوي دلاهــة (ه ., • ) بــين متوســطي درجات طلاب المجموعة التجريبية الثانبــة

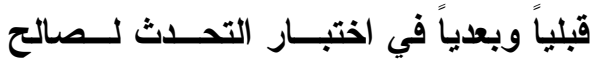
التطبيق البعدي" كما في الجدول الآتي: و لاختبار صحة هـــا الفـرض قــام

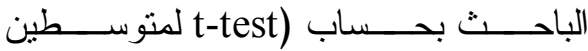
مرنبطين) وذللك من اجـلـ المقارنـــة بــين

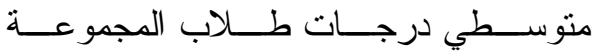
التجرييية الثانية قبل وبعـــ (نـــ الــدعم

$$
\text { (الخارجي). }
$$

ومما سبق تم قبول الفــرض الثـاني

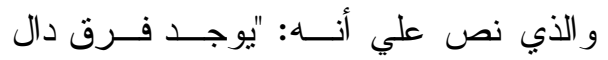
إحصائياً عند مستوي دلالـــة (0. . •) بــين

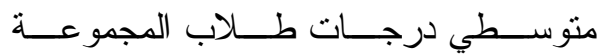
التجريبية الأولي قبلياً وبعــدياً فـــي اختبــار التحدث لصالح التطبيق البعدي". r - اختبار صحة الفرض الثاني:

قام الباحث باسـتخدام اختبـــار (ت) وذللك للتحقق من صحة هذا الفرض و الــذي الــي نص علي أنه: "يوجد فرق دال إحصائياً عند جدول (r)

يوضح المتوسطات والاتحر افات المعيارية وقيمة "ت" المحسوبة ودلالتها الإحصائية بين درجات المجموعة التجريبية الثانية في التطبيقين القبلي والبعدي للاختبار التحلث التجريبية الثانية في التطبيقين القبلي والبعدي للاختبار التحدث

\begin{tabular}{|c|c|c|c|c|c|c|c|}
\hline $\begin{array}{l}\text { التأثير } \\
\text { حجي }\end{array}$ & مستوي & قيمة "ت & الحرية & الاعحر اف & المتوسط & التطبيق & المستوي \\
\hline \multirow[b]{2}{*}{ - ,99 } & \multirow{2}{*}{ مستوي } & \multirow{2}{*}{$r \wedge, \wedge r$} & \multirow{2}{*}{ rq } & T, ro & $1 T, \leqslant 4$ & القبلي & \multirow{2}{*}{ التحثث } \\
\hline & & & & $r, \ldots$ & $r Y, V Y$ & البعدي & \\
\hline
\end{tabular}

يتضح من الجدول السابق أن قيمة "ت" التجريبية الثانية التي تستخدم (نــــ الــدعم

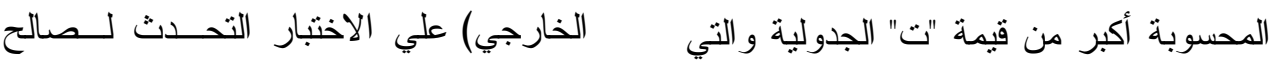

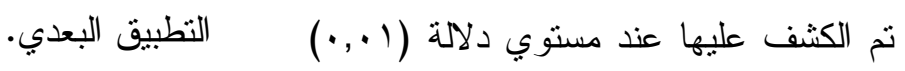
وبالرغم من أن نتيجة الاختبار توضح

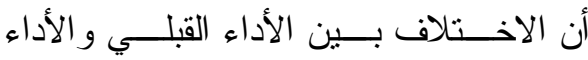

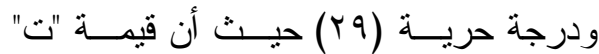

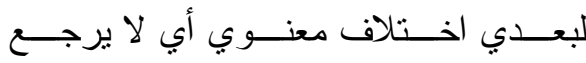
الجدولية تساوي (Y,VT)، وهذا الفــرق دال

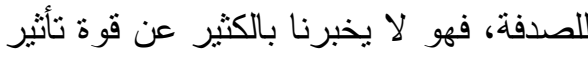
إحصائيا لصالح النطبيق البعدي مما يـشير إلي وجود فرق ذو دلالــة إحـصائية بـين لـين

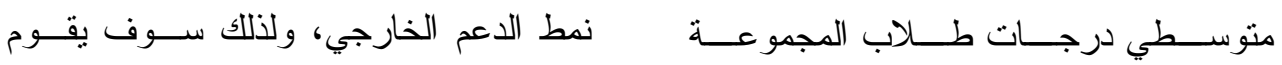


r- اختبار صحة الفرض الثالث:

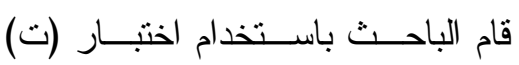

وذللك للتحقق من صحة هذا الفرض و الــــي نص علي أنه: "يوجد فــرق دال إحــصائياً

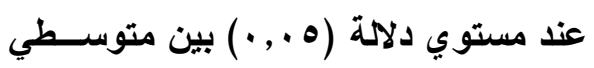

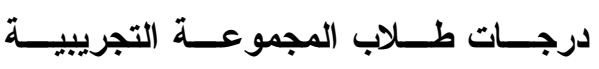

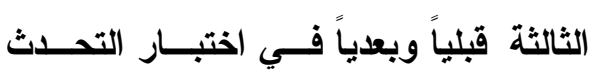
لصالح التطبيق البعدي" كما فــي الجـدول ولاختبار صحة هـــا الفــرض فــام

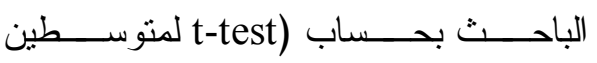
مرتبطين) وذلك من اجــل المقارنـــة بــين

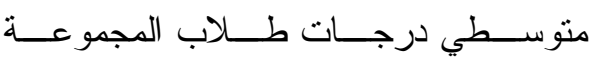

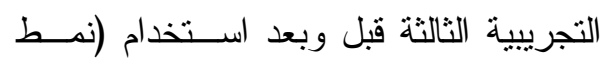
الدعم العرضي).

الباحث بحساب إحصاء مربع إيتا لحسـاب

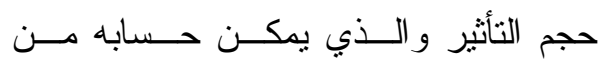
المعادلة:

$$
\operatorname{Eta}^{2}=\frac{t 2}{t 2+(N-1)}
$$

ويلاحظ الباحث من الجدول ( 3 )

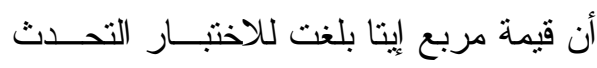
(79 , • ) و هذا يدل علي درجة تأثير المعالجة

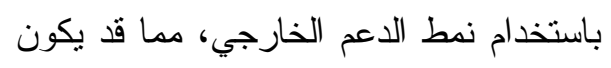

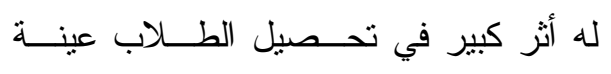
البحث. ومما سبق نم قبول الفرض الثـاني

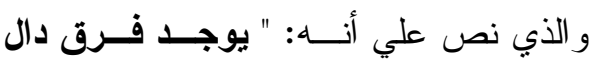
إحصائياً عند مستوي دلالة (ه . . • ) بـين لودين

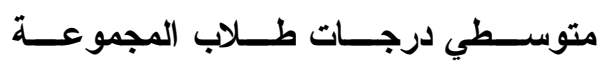
التجريبية الثانية قبلياً وبعدياً فــــي اختبــار التحلث لصالح التطبيق البعدي".

جدول ( ) يوضح المتوسطات والاتحر افات المعيارية وقيمة ت المحسوبة ودلالتها الإحصائية

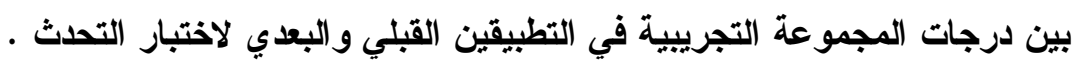
التجريبية في التطبيقين القبلي والبعدي لاختبار التحدث

\begin{tabular}{|c|c|c|c|c|c|c|c|}
\hline التأثير & مستوي & قيمة "ت & الحرية & الالحراف & المتوسط & التطبيق & المستوي \\
\hline & \multirow{2}{*}{ مستوي ل ـ., ــ } & \multirow{2}{*}{$r Y, \leqslant V$} & \multirow{2}{*}{ rq } & $r, \Lambda \Lambda$ & $1 \varepsilon$ & القبلي & \multirow{2}{*}{ ختبار التحدث } \\
\hline & & & & ז, . . & ro,rr & البعدي & \\
\hline
\end{tabular}

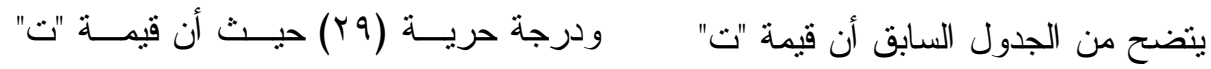

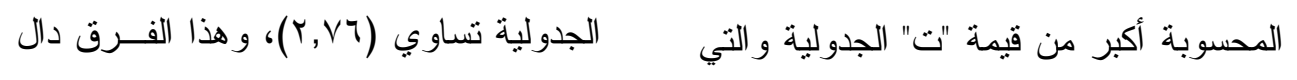

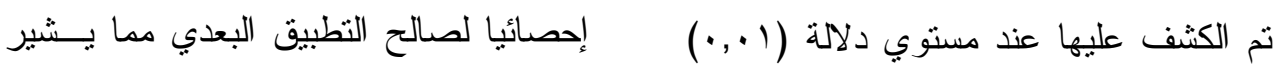


(Schiaffino, Garcia, \& Amandi,

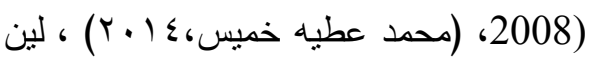

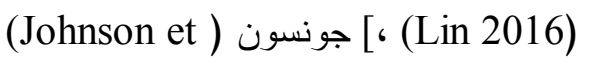
2009

$$
\text { التعلم التكيفية في التعليم و التدريب . }
$$

و يمكن اعزاء هذه النتيجــة الــي

المميزات و الفو ائد التي توفرها بيئة الــتعلم التكيفية وذللك نظر اً لأنها أصبحت بيئة أكثر

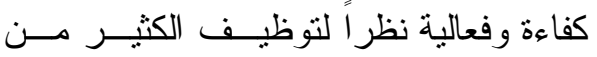

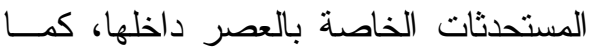
أنها تعتبر بيئات رخيصة التكاليف مقارنــة بالبيئات التعليميــة الأخــري كمـــا يـســل استخدامها في كل الدور ات التي تــتن عبــر الإنترنت، ويتم تحديــــــت ترنيــب التعليمــات داخلها من قبل الطلاب وليس من قبل المعلم

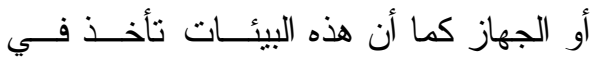
الاعتبار أن كل شخص لديه خبرة مختلفـــة وبالتالي تكون معرفته و احتياجاته مختلفــة، مما يعمل علي مر اعاة الفروق الفردية بـين

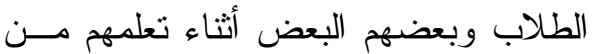

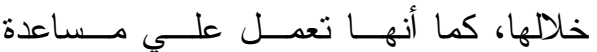

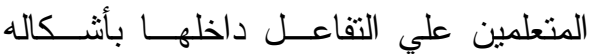
المختلفة من خلال نوفير تلك الاثكال داخلها حتي يتم استخدامها مــن خـــلد الطــلاب. - (Fischman, 2011) لذا يمكن اعز اء هـــا التقـــوق إلــي المميز ات التي يوفرها نمط الدعم الــــاخلي
إلي وجود فرق ذو دلالـــة إحــصائية بــين

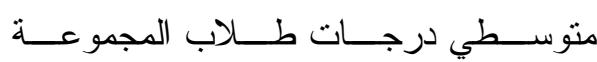
التجريبية الثالثة في اختبار التحدث لـــــالح التطبيق البعدي.

ومما سبق تم قبول الفــرض الثالـــث

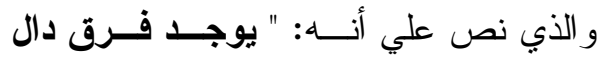
إحصائياً عند مستوي دلالة (0., •) بـين

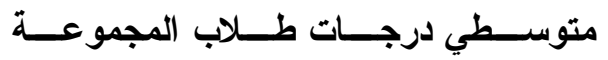

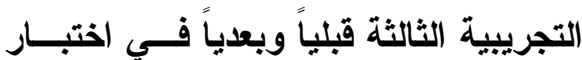
التحدث لصالح التطبيق البعدي". تفسير نتيجة الفروض (الاول ، الثاني والثالث): توصلت الفروض (الاول ،الثـاني

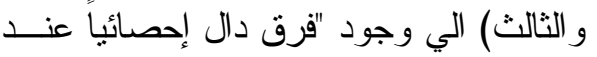
مستوي دلالة (0., •) بين منوسطي درجات طلاب المجموعات التجريبية الــثلاث قبليــاً وبعدياً في اختبار التحدث لــــالح النطبيــق البعدي". وتنقق هذه النتيجة مع دراسة كــلـ من شيو Sheu (2000)، إيمان عبد العاطي

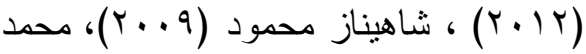

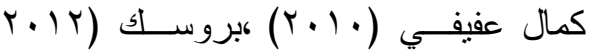
Prosk ( حيث توصلت هذه الدر اسات الي اهمية نظم

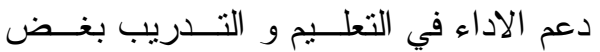
النظر عن نمطها. كما انها تتفق مع در اسة كــل مــن

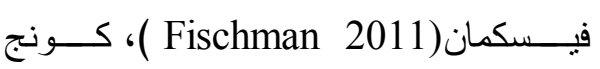

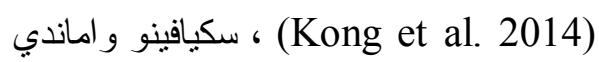


علي تخطي و تجاوز العقبات، كما ير اعــي

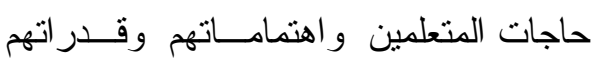

و اساليب تعليمهم. (Beale, I.L., 2005).

ع -اختبار صحة الفرض الر ابع:

حيث قام الباحث باســتخدام اختبــار

(ف) وذلك للتحقق من صحة الفرض الرابع من فروض البحث، و الذي نص علي أنه: "لا يوجد فرق دال إحصائياً عند مستوي دلالة

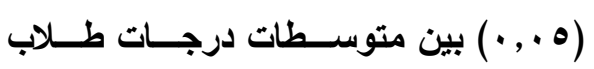
المجموعات التجريبية الثتلاث في التطبيـق متون البعدي لاختبار التحدث باللغة الاتجليزيـــة"

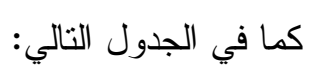

و التي تتمنل في أنه يتــيح للطــلاب جمــع المعلومات التي يحتاجون إليها داخل البيئــة

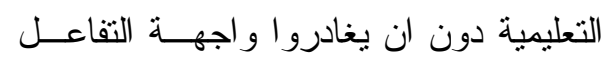
ودون التوقف عن العمل في النشاط ،ويقــدم لهم النصائح و الارشـــادات التــي تلــزمهر بالمو اقف التعليمية المختلفة، كما انه يعهـلـ

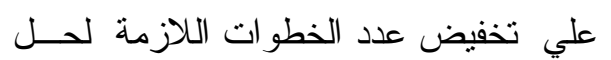

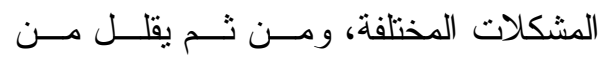
احساس المتعلم بالفشل، حيث بتثني للمــتعلم اتمام مهمته المطلوبة من خلاد الاستفادة من بل بلني

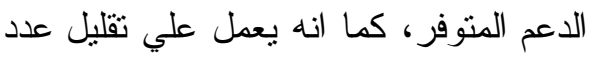

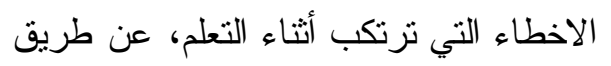

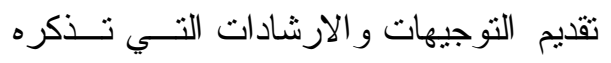
بالخطوات التي يجب أن يتخذها، مما يساعد

جدول (•)

يوضح تحليل التباين في اتجاهواح One Way ANOVA بين المجموعات الثلاثة في جي التطبيق البعدي لاختبار التحدث باللغة الاتجليزية

\begin{tabular}{|c|c|c|c|c|c|c|}
\hline مستوي & قالمحسوبة & متوسط & درجة & مجموع المربعات & مصدر التباين & التطبيق \\
\hline \multirow{3}{*}{$\cdot, \cdot}$, & \multirow{3}{*}{$r \leqslant, 99$} & $r), q$. & r & $\sum r \mid, \wedge$. & بين المجموعات & \multirow{3}{*}{ البعدي } \\
\hline & & $\Lambda, \varepsilon r$ & AV & $V r \varepsilon, r$. & داخل المجمو عات & \\
\hline & & & $\wedge 9$ & 1107 & الكلى & \\
\hline
\end{tabular}

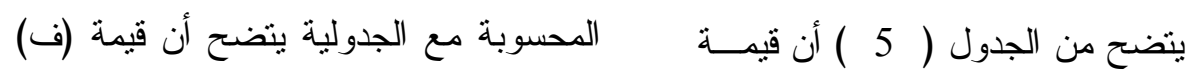

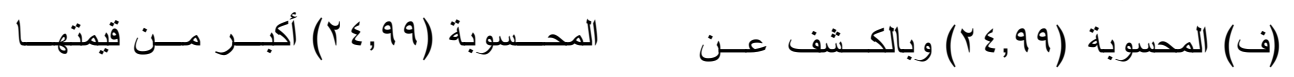

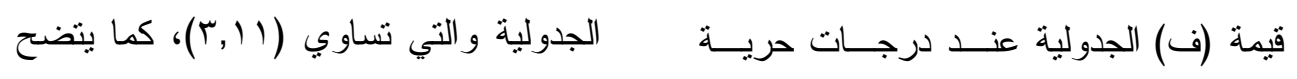

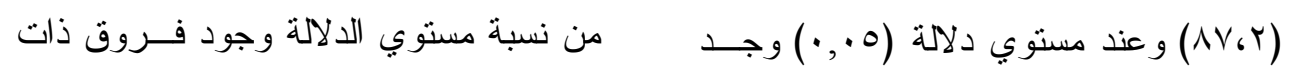

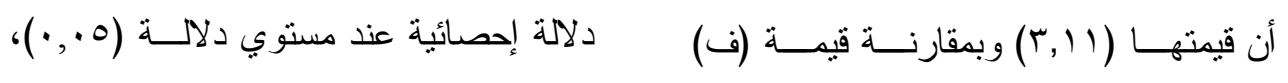




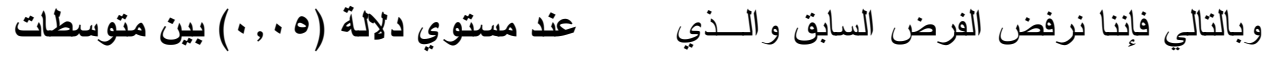

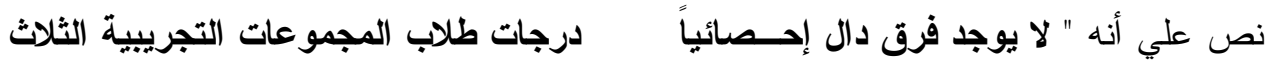

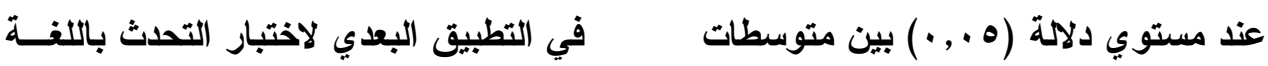

$$
\begin{aligned}
& \text { درجات طلاب المجموعات التجريبية الثلاث الاجليزية". } \\
& \text { ولتحديد هذا الفرق بين المجموعـات } \\
& \text { في التطبيق البعدي لاختبار التحدث باللغــة } \\
& \text { الثناث قام الباحث بتطبيق اختبــار تـــوكي }
\end{aligned}
$$

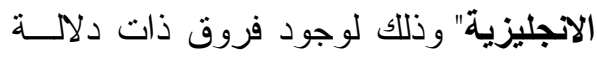

$$
\begin{aligned}
& \text { Tukey }
\end{aligned}
$$

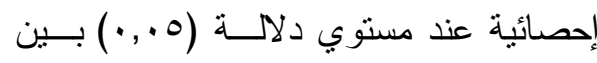

$$
\begin{aligned}
& \text { وكانت النتائج كما في الجدول التالي: }
\end{aligned}
$$

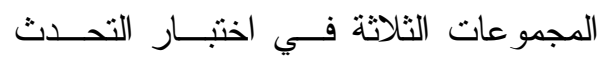

\begin{tabular}{|c|c|c|c|c|}
\hline$r$ & تجاتس & 1 & العينة & المجموعات \\
\hline$r, 0$ & $0, r$ & - & $r$. & دعم داخلي \\
\hline r,o- & - & $0, r-$ & r. & دعم خارجي \\
\hline - & r.o & $r, \Lambda-$ & $r$. & دعم عرضي \\
\hline $1, \ldots$ & $1, \ldots$ & $1, \ldots$ & \multicolumn{2}{|c|}{ مستوي الدلالة } \\
\hline
\end{tabular}

$$
\begin{aligned}
& \text { وبالتالي فإننا نقبل الفرض البــديل و الــــي } \\
& \text { ينص علي أنه " يوجد فــــن دال إحــــائياً }
\end{aligned}
$$

جدول (†)

يوضح تحليل توكي بين متوسطات درجات المجموعات الثلاثة لاختبار التحدث

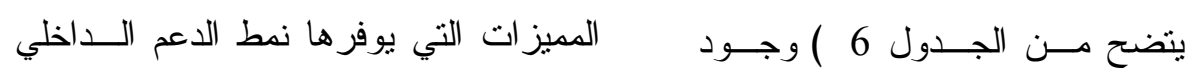

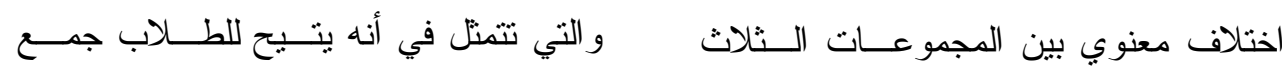

المعلومات التي يحتاجون إليها داخل البيئــة

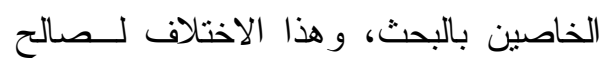

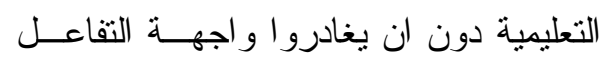

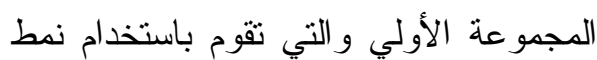

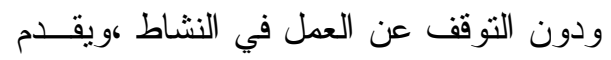

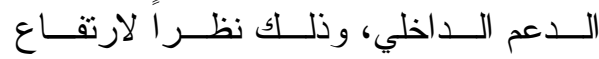

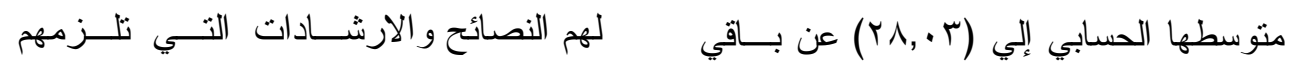

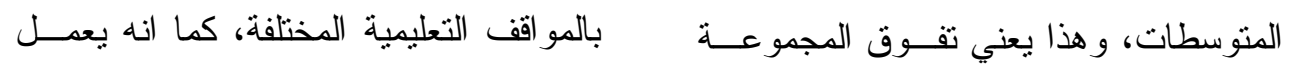

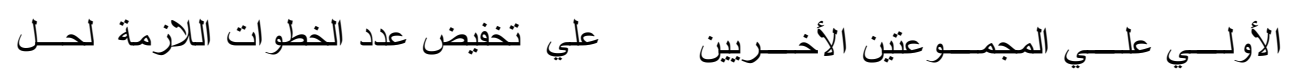

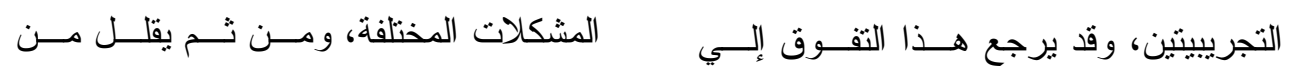




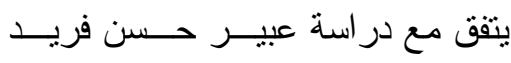

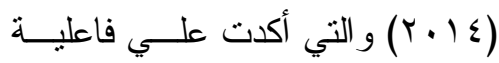
استخدام أسلوب الموديو لات التعليميــة ولتهـ في تتمية التحصيل و الجو انب المعرفية المختلفة للمهار ات التصميمية الخاصة

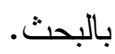

بـ كما تتميز البيأـــة التعليميـــة التكيفيــة

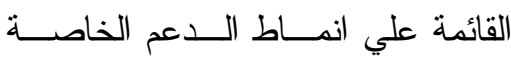

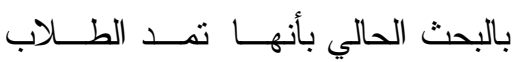

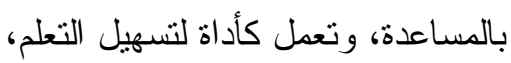
وتوسع وتتمي مهار ات الطلاب العقلية و العملية، عن طريق دعامات الــتعلم

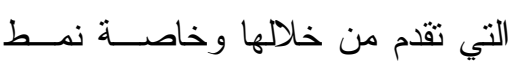

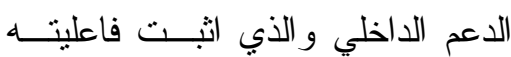

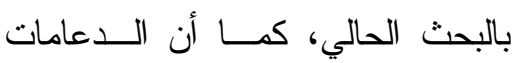
تمكن الطلاب من إنجاز المهام التي لا

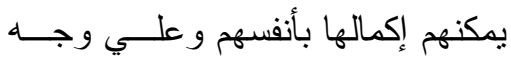
الخصوص المهام التي تطلبتها مــنهم البيئة التكيفية الخاصة بالبحث، تستخدم تحديداً لمساعدة الطلاب عند حساجنهم لها وبشكل مؤقت، حيث يجب أن يتت

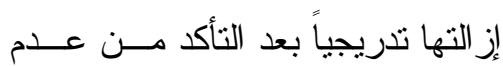

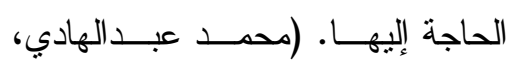
$(T V, Y \cdot))$

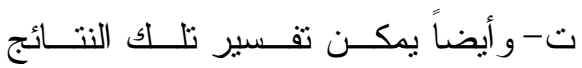

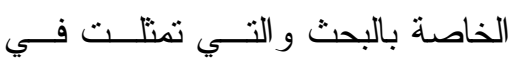
فاعلية نمط الدعم الداخلي فـــي البيئــة
احساس المتعلم بالفشل، حيث بيتثي للمــتعلم اتمام مهيته المطلوبة من خلال الاستفادة من بن الدعم المنوفر، كما انه يعمل علي تقليل عدد

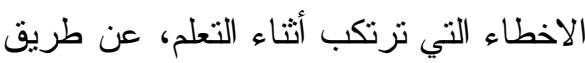

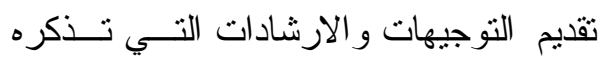

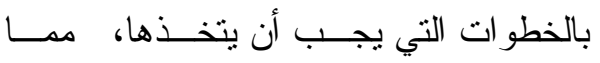

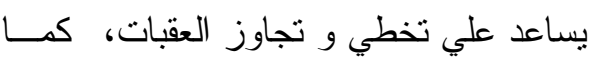
ير اعي حاجــات المتعلمــين و واهتمامــاتهم وقدر اتهم و اساليب تعليمهم • Beale, I.L.,

\section{تفسير النتائج ومناقشتها:}

أ- ـ يمكن للباحث إرجاع النتـائج الــسابقة لفاعلية أنماط الدعم في بيئات الــتـعلم التكيفية في تتمية مستويات مهــار ات التحدث باللغة الانجليزية لدي طــلاب

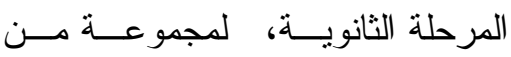

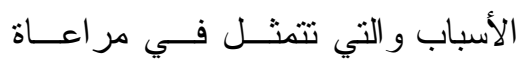
البحث الحــالي للأســس و المعـايير التصميمية السليمة عند تصميم البيئــة

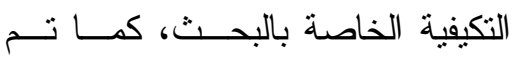

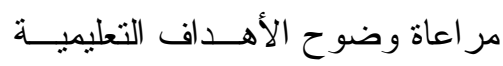

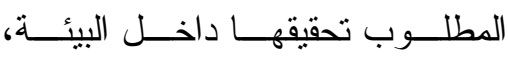
وملاعمتها لخصائص المتعلمين عينـــة البحث واحتياجاتهم الفعلية وهم طلاب الصف الثاني الثانوي، مع العمل علي ولن تقديم المحتوي للطلاب فــي صـــورة مجموعة من الوحدات التعليمية، و وهذا 
التأمل). (رســالة ماجسـنير غيـر

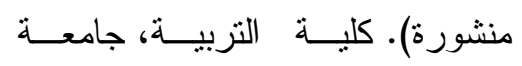

$$
\text { الاسكندرية. }
$$

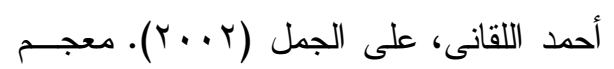

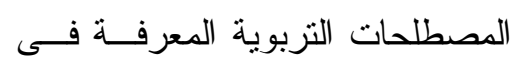

المناهج وطرق التــدريس. القــاهرة:

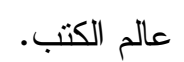

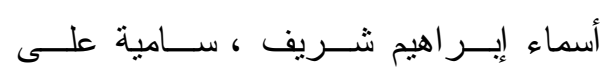

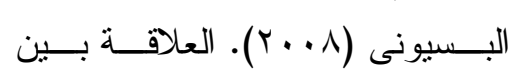

الميول القر ائية إلكترونية وبين بعض لهض

مهار ات التفكير الناقد. المؤتمر الثنامن

للجمعية المصرية للقر اعة و المعرفة-

$$
\text { مصر ، القاهرة، بوليو. }
$$

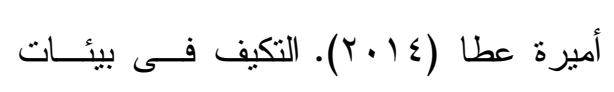

التعلم: تحدى جديد من اجل الافضل، رطل

مجلة التعليم الاكترونى ، متاح على: جلى جلى الإضل http://emag.mans.edu.eg

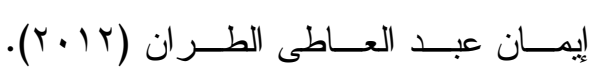

اختلاف أنماط تصميم نظم دعم الأداء

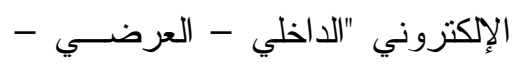

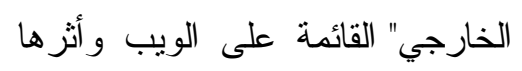

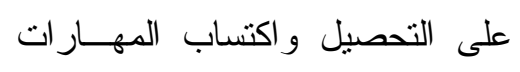

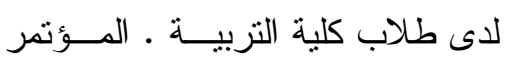

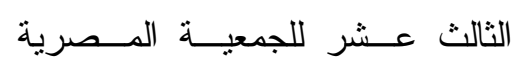

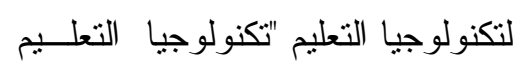

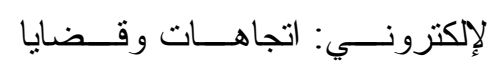

معاصرة". دار الــضيافة. الجمعيــة
التكيفية إلي اعتماد البحث الحالي علي

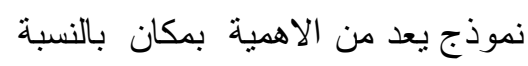

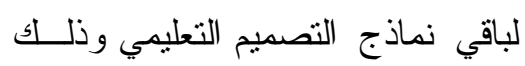

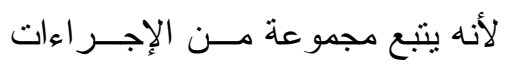

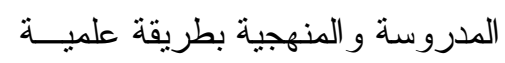

صحيحة، مما أدي إلي إتاحـــة بيئــة

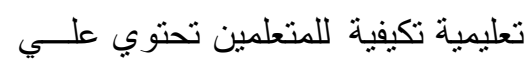

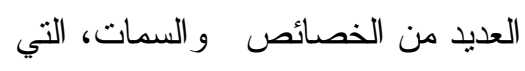

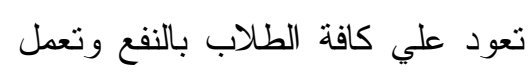

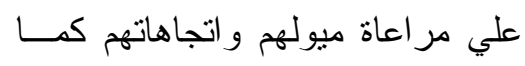

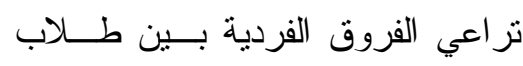

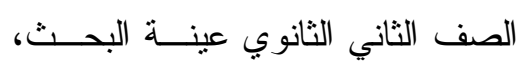

وتوفر لهم الدعم المناسب بكافة اشكاله

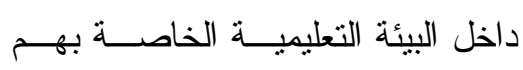

. ( (Azevedo, et at, 2003)

Cavanaugh2004)

\section{المراجع}

أولاً : المراجع العربية:

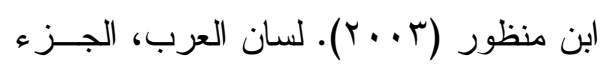

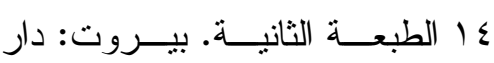

$$
\text { صادر • }
$$

أحمد إبر اهيم موســى حجــازي (9 . . ب).

فاعلية استخدام استر اتيجيات الـتـعلم

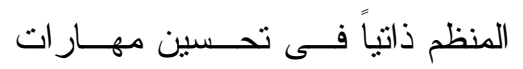

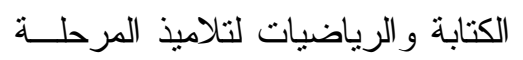

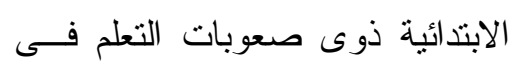

ضوء الأسلوب المعرفي (الانــدفاع) 


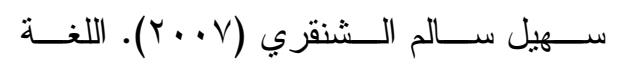
الإنجليزية مطلــب حيــوي للتعلــيم

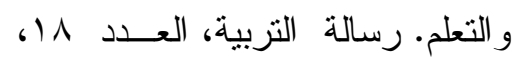
سلطنة عمان.

شاهيناز محمود أحمـــ. (9 . . r): فاعليــة

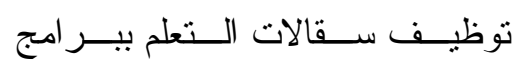

الكمبيوتر التعليمية في تتمية مهار ات

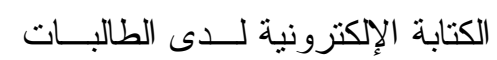
معلمات اللغة الإنجليزيـــة. المـــؤنمر العلمي الثاني عشر للجمعية المصرية

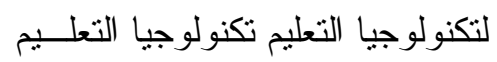

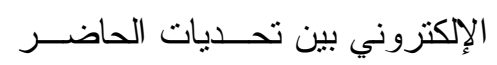

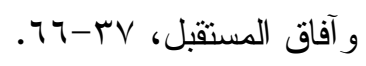

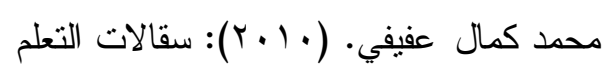

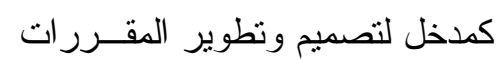
الإلكترونية ومدى فاعليتها على كـلـل من أداء الطلاب في التعلم القائم على الأى المشروعات و الرضا عن التعلم فــي لئي البيئة الإلكترونية. تكنولوجيا التربية.

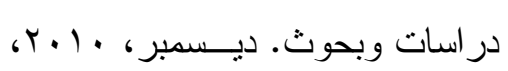
.

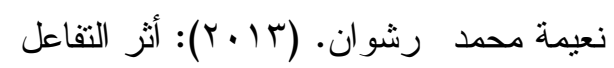

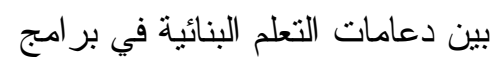

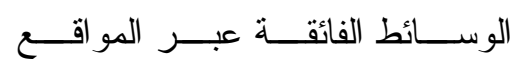
الإلكترونية و الأسلوب المعرفي فــي تتمية بعض جو انب التعلم لدى طلاب
المصرية للمناهج وطرق التـدريس. جامعة عين شمس. القاهرة.

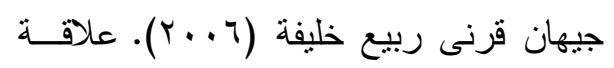

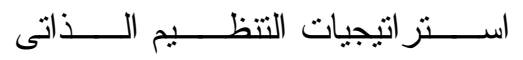

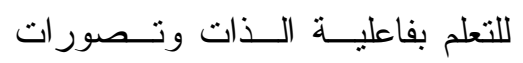
التعلم لاى طلاب المرحلة الجامعيــة. (رسالة ماجـستير غيــر منـشورة)

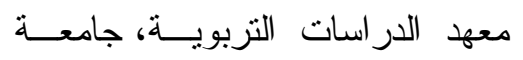
القاهرة. - معثة

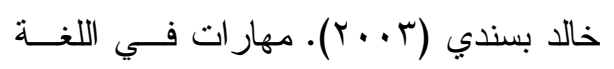

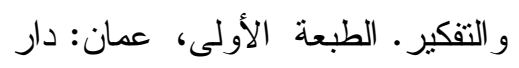

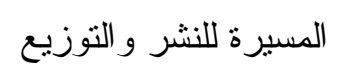
رياض بن احمد ابر اهيم زيلعسى (9 . . r).

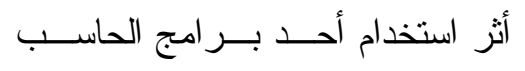

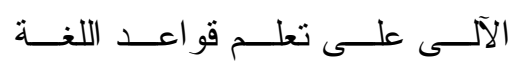

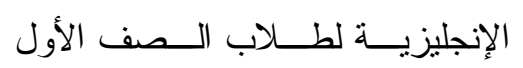
الثانوي بمدينة جدة. رسالة ماجستنر

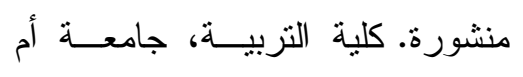

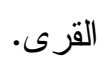
زينب حسن حامد السلامى (^ . . r):" أثــر التفاعل بين نمطين من سقالات التعلم

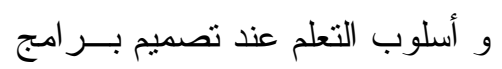

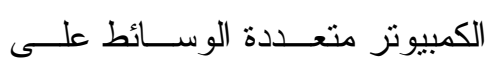

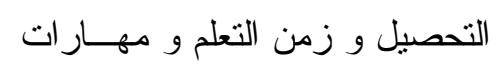

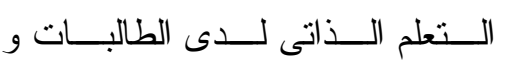

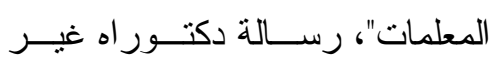
منشوره ،كلية البنات ، جامعة عــين 
القاهرة. الجمعية المصرية للمنــاهج وطرق التـدريس. (1) (1). مـارس $.9 V-0 Y$

عبدالعزيز طلبة عبدالحميد (11) بـ). أنــر تصميم استر اتيجية للتعلم الإلكترونــي قائمة على التوليف بين أساليب التعلم

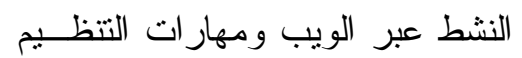
الذاتى للتعلم على كل من التحــصيل

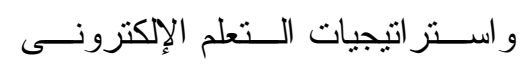
المنظم ذاتياً وتتمية مهار ات التفكيــر التأملى. مجلة كلية التربية: جامعسـة المنصورة.

فؤاد البهي الــسيد(9V9 ()). علــم الــنفس

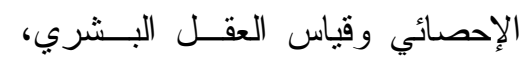
طץ،القاهرة، دار الفكر العربي.

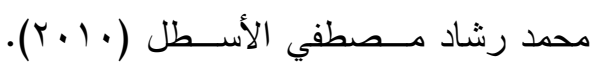
مستوي المهارات القرائية و الكتابيــة المة لاي طلبة الصف السادس وعلاقتـــه بتلاوة وحفظ القران الكريم. ماجستير غير منشورة. الجامعــة الإســلامية بغزة، كلية التزبية. محمد عطية خميس (r. . . ج ج). منتوجـات تكنولوجيا التعليم. القاهرة: مكتبة دار الكلمة. محمد عطية خمـيس (ع ا.بr): المحتـوى الإككتروني التكيفــي و الـــكي (1) (1)،
كلية التربية بالعريش. مجلة القــر اءة

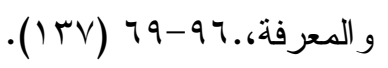

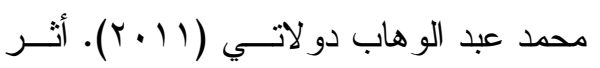
اختلاف مستويات التوجيه في بر امج الكمبيوتز متعددة الوسائط على تتمية

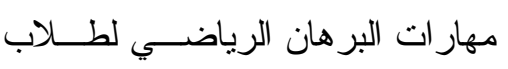
الصف الأول الثانوي، رسالة دكتور اه

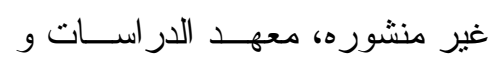
البحوث التزبويه، جامعة القاهره.

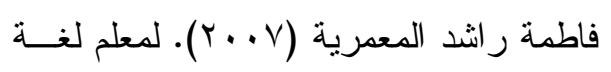
انجليزية ناجح. رسالة التربية، العـدد 11 ا، سلطنة عمان.

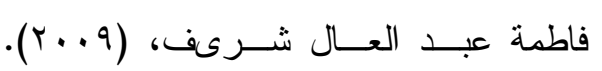
برنامج مقترح لتتمية مهار ات التعبير الثفوي الابداعي لدى تلاميذ المرحلة

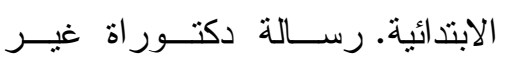

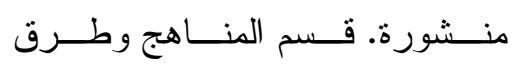
التدريس، كلية التزبية، جامعة عــين شمس: القاهرة.

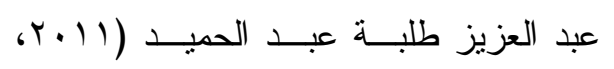
مارس). أثز التفاعل بين أنماط الدعم الإلكتروني المنز امن وغير المنز امن

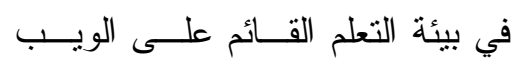
وأساليب التعلم على التحصيل وتتمية لتئية مهار ات تصميم و إنتاج مصادر التعلم

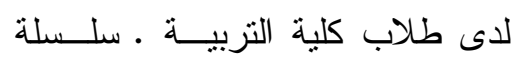
در اسات في المناهج وطرق التدريس. 


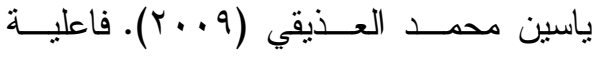

$$
\begin{aligned}
& \text { استر اتيجية التساؤل الذاتي في تتميـــة } \\
& \text { بعض مهار ات الفهم القرائسي لــــي }
\end{aligned}
$$

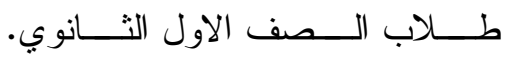

$$
\begin{aligned}
& \text { ماجستير غير منــشورة. جـامعي ام } \\
& \text { القري، كلية التزبية. }
\end{aligned}
$$$$
\text { ثانياً : المراجع الأجنيية: }
$$

Abu- Ghararah, A.H. (2005). Teaching English As A Foreign language. Tawbah library.

Aguirre, S. \& Quemada, J. (2012). E-learning Systems Support of Collaborative Agreements: A Theoretical Model. Educational Technology \&Society. 15 (4). 279-295.

Alessi, S.M., \& Trollip, S.R. 32001). Multimedia for Learning, Methods and Development, Third ed., Boston: Allyn and Bacon, Inc.

Ani Grubii Slavomir Stankov Branko itko. "Adaptive Courseware: A Literature Re- view ". In: (2015) .

Azevedo, R. \& Hadwin, A.F. (2003). Scaffolding selfregulated learning and metacognition-Implications for the design of computerasedscaffolds Instructional

$$
\begin{aligned}
& \text { الجمعية المصرية لتكنولوجيا التعليم، }
\end{aligned}
$$

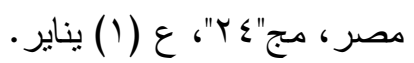

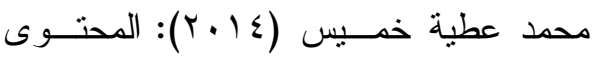

$$
\begin{aligned}
& \text { الإلكترونـــي التكيفــي و الـــكي(ب)، } \\
& \text { الجمعية المصرية لتكنولوجيا التعليم، } \\
& \text { مصر، مج" ع ب"، ع (Y) ابريل. } \\
& \text { منصور سعيد محمــ (1) (Y). اتجاهـات }
\end{aligned}
$$

أعضاء هيئة التـدريس ومعسـاونيهم

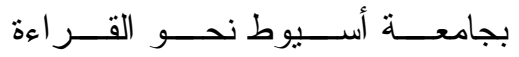

الإككترونية: دراسة ميدانية. المجلــة

العلمية لكلية الآداب، جامعة اسيوط.

$$
\text { العدد Vr. ص ص q- }
$$

نبيل جاد عزمي الديب (1 ( . . ب). التصميم التعليمي للوسائط المتعددة .المنيا :دار

$$
\text { الهدى للنشر و التوزيع. }
$$

نبيل عبدالهادي؛ وعبد العزيز أبو حشىش؛

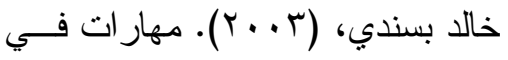
اللغة و التقكير • الطبعة الأولى، عمان:

$$
\text { دار المسيرة للنشر و التوزيع. }
$$

نيفين محمد عبدالعزيز إبــر اهيم (10 (Y).

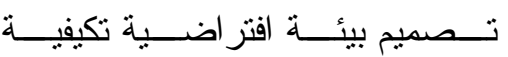

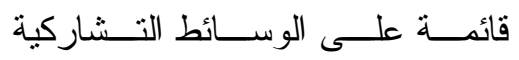
لتتمية مهار ات إدارة المعرفة و التعلم الإلكتروني المنظم ذاتياً لدى طـــلاب

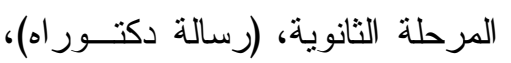
كلية التربية، جامعة المنصورة. 
performance technology.

Performance improvement, 43(4),-28-32,-Retrieved-

from:

http://www.ispi.org/publicati ons/pitocs/piApr2004.htm\#s pectrum

Conlan, O., et al., An architecture for integrating adaptive hypermedia services with open learning environments. Proc. of ED-MEDIA, 2002: p. 24-29.

Dabbagh, N., \& Kitsantas, A. (2015). Using web-based training: Performance support systems for education and training :could this be the next generation .

Deborah, L. J., Baskaran, R., Kannan, A. (2014) Learning styles assessment and theoretical origin in an Elearning scenario: A survey. Artificial Intelligence Review 42(4): 801-819. Google Scholar, Crossref .

Dimitrios Georgiou Sotirios Botsios. "Re- cent Adaptive e-learning contributions towards a standard ready architecture". In: (2008).

Ekaterina Vasilyeva Mykola Pechenizkiy Seppo Puuronen. "Knowledge Manage- ment Challenges in Web-Based Adaptive e-
Science, 33(5), 381-382 .

Barkera, P., Van Schaika, P. \& Famakinwa, O. (2007).

Building Electronic

Performance Support

Systems for First Year University Students. University of Teesside. UK. 44(3). 243-255.

Beal,I.L.(2005).Scaffolding and Integrated Assessment in Computer Assisted Learning (CAI)for Children with Learning Disabilities . Australasion Journal of Educational Technology ,21 (2).

Beal,I.L.(2005).Scaffolding and Integrated Assessment in Computer Assisted Learning (CAI)for Children with Learning Disabilities . Australasion Journal of Educational Technology ,21 (2).

Bull, K.S \& Kimball, S.L (1999). Scaffolding in computer mediated learning. Retrieved from

http://home.okstate.edu/hom epage.nsf/toc/ epsy $5720 \mathrm{em} /$

Cavanagh, T.B. (2004). The new spectrum of support: Reclassifying human 
Performance Improvement Quarterly, 8, 47-93.

Goh, C. \& Burns, A. (2012). Teaching speaking: A holistic approach. Cambridge: Cambridge University Press.

Grimshaw, S. (2007). Electronic books: Children's reading and comprehension. British Journal of Educational Technology, 38(4), 583-599.

Gustafson, K.L. (2000). Designing technology - based performance support. Educational technology, 40(1). 38-44, Retrieved from:

http://www.bookstored.com/ etp/gustafson.pdf .

Huff, D. C. (2007). The effects of EPSS selection controls on incidental learning, performance time and task accuracy. Doctoral dissertation. Proquest Dissertations and Theses Online database. (3243082). Johnson, B. G., Phillips, F., \& Chase, L. G. (2009). An intelligent tutoring system for the accounting cycle: Enhancing textbook homework with artificial
Learning Systems". In: (2005) .

Esichaikul, V, Lamnoi, S., \& Bechter C. (2011). Student modlling in adaptive elearning systems. Knowledge management \& E-learning: An International Journal(KM\&El),3(3),342355

Felder R. M. Silverman L. K. "Learning and teaching styles in engineering education". In: (2002). url: http://www.ncsu.edu/ felderpublic/ 20Papers/LS1988.pdf.

Feng, Z. (2007). The Perceptions of Chinese Junior High and Senior High Students Regarding the Teaching and Learning of English Listening and Speaking Skills. Doctoral dissertation, Texas Tec University.

Fischman, J. (2011). The rise of teaching machines, Retrieved on May 23, 2011 from http://chronicle.com/article/T he-Rise-of-Teaching-

Machines/127389/

Gery, G. (1995). Attributes and behaviors of performancecentered systems. 
technology (pp. 651-684). Bloomington: AECT.Google Scholar

Lin, C. C., Guot, K. H., \& Lin, Y. C. (2016). A simple and effective remedial learning system with a fuzzy expert system. Journal of Computer Assisted Learning, 32(6), 647-662. doi:

10.1111/jcal.12160.CrossRef Google Scholar.

Mary

Pulverness, Melanie

Williams ( 2014). The TKT Course: Teaching Knowledge Test . Cambridge University Press.

McKenzie J. (1999). Scaffolding for Success. The Educational Technology Journal, 9(4). Retrieved from: http://www.Fno.org /dec99/scaffold.html

McLoughlin, C. \&Marshall, L. (2000). Scaffolding: A model for learner support in an online teaching environment. Teaching and learning Forum. Retrieved from:

http://cea.curtin.edu.au /tlf/tlf2000/mcloughlin2.htm

Netherlands .

Nguyen, L. \& Do, P. (2008) Learner model in adaptive learning. Proceedings of intelligence. Journal of Accounting Education, 27(1), 30-39. Cross Ref Google Scholar.

Klasnja Milicevic. "E-Learning personaliza- tion based on hybrid recommendation strat- egy and learning style identification". In: (2011).

Kommers, P., Stoyanov, S., Mileva, N., \& Martinez, M. K. (2008). The Effect of Adaptive Performance Support System on Learning Achievements of Students. International Journal of Continuing Engineering Education and Lifelong Learning. 18 (3). 351-365.

Kong, S. C., Chan, T.-W., Griffin, P., Ulrich, H., Huang, R., Kinshuk,... Yu, S. (2014). E-learning in school education in the coming 10 years for developing $21 \mathrm{st}$ century skills: Critical research issues and policy implications. Journal of Educational Technology \& Society, 17(1), 70-78Google Scholar.

Lee, H. (2003). Adaptive instructional systems. In D. H. Jonassen (Ed.), Handbook of research on educational communications and 
Slavi Stoyanov [slavi. Stoyanov @ ou.nl] and Paul Kirschner the Educational Technology Expertise Center, Open University of the Netherlands Educational Technology Research and Development June 2004, Volume 52, Issue 2, pp 4154 Available at: https://link.springer.com/arti cle/10.1007/BF02504838

(Or) at : Stoyanov, S. \& Kirchner, P. ETR\&D (2004) 52: 41. https://doi.org/10.1007/BF02 $\underline{504838}$

Stoyanov, S. (2001). Mapping in the educational and train- ing design. Unpublished doctoral dissertation, University of Twente, The Chieu, V. M. (2005). Constructivist learning: An operational approach for designing adaptive learning environments supporting cognitive flexibility (Unpublished doctoral dissertation). Louvain-laNeuve, BE: Université catholique de Louvain.
World Academy of Science, Engineering and Technology, 35, 396-401.

O'leonard, K. (2005). Performance support systems: how to improve user productivity and lower the costs of software applications training, Bersin \& Associates, Retrieved 18 October, 2011 from: http://webcache.gooleuserco ntent.com/search?Hl=ar\&rlz $=1 \mathrm{R} 2 \mathrm{TIL}$

Raybould, B. (1991). An EPSS Case Study: Prime Computer. Handout given at the Electronic Performance Support Conference, Atlanta, GA.

Schiaffino et al., 2008- S. Schiaffino, P. Garcia, A. Amandi eTeacher: providing personalized assistance to e-learning students Computers \& Education, 51 (4) (2008), pp. 1744-54.

Sheu, Feng-Ru.(2000).Design of Electronic Performance Support Systems . Retrieved from ERI Cdatabase (ED455807. 
learning environments based on the item response theory: Possibilities and challenges. Journal of Computer Assisted Learn- ing, 26, 549 562.

Winnips, J , Mcloughlin, C. (2000). Applications \&categorization of software. Based scaffolding. World conference or Educational Multimedia, Hypermedia \& Telecommunication 2000(1), 1798-1799. Retrieved from: http:lldi.aace.org 11763.

Zhao, R. (1998). Research and Development of a ComputerBased Scaffolding Strategy (Instructions Strategies, Eighth-Grade). (CD- ROM) Abstract from: Dissertation Abstracts International Item: 19836357.

Zhao, X., \& Okamoto, T. (2008, July). A device-independent system architecture for adaptive mobile learning. In Advanced Learning Technologies, 2008. ICALT'08. Eighth IEEE International Conference on (pp. 23-25). IEEE.
Tricot, A, Pierre-Demarcy, C. \& El Boussarghini, R. (2000). Specific Help Devices For Educational Hypermedia. Journal of Computer Assisted Learning, 196,102113. University of Pretoria (2001). Design Standards and Principles.

VanLehn, K. (2011). The relative effectiveness of human tutoring, intelligent tutoring systems, and other tutoring systems. Educational Psychologist, 46(4), 197221.

Vassileva, J. (2012). Motivating participation in social computing. User Modeling and User-Adapted Interaction.

Wang (2011)“Application of context-aware and personalized recommendation to implement an adaptive ubiquitous learning system".

Wauters, K., Desmet, P., \& Van den Noorgate, W. (2010). Adaptive item-based 